\title{
AGR-3/4 Experiment Preliminary Mass Balance
}

John D. Stempien

Paul A. Demkowicz

Jason M. Harp

Philip L. Winston

August 2018

The INL is a

U.S. Department of Energy

National Laboratory

operated by

Battelle Energy Alliance

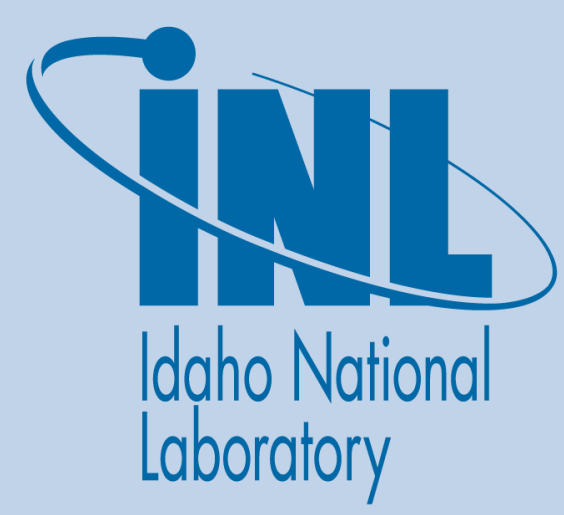

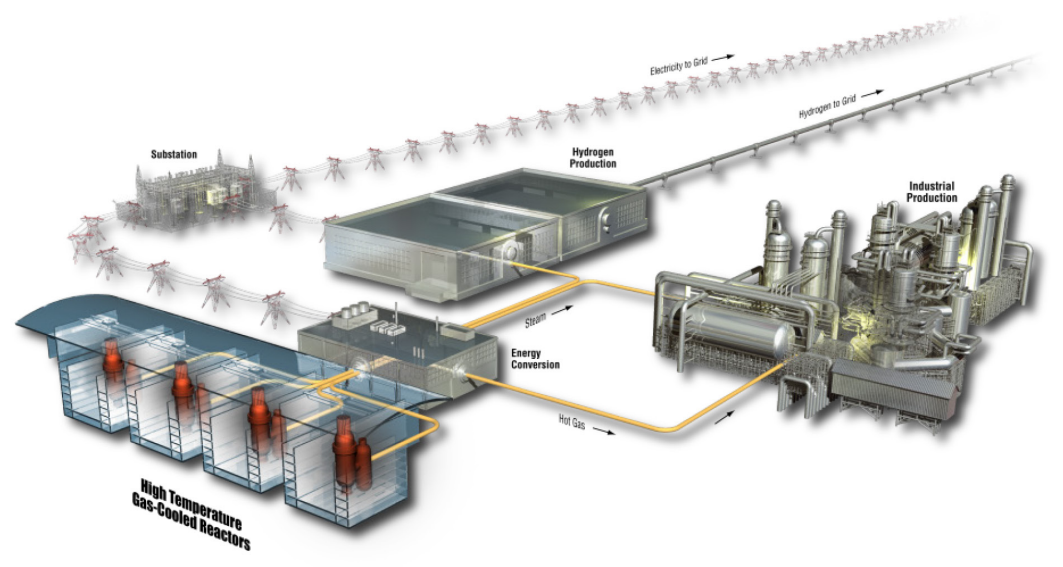




\section{DISCLAIMER}

This information was prepared as an account of work sponsored by an agency of the U.S. Government. Neither the U.S. Government nor any agency thereof, nor any of their employees, makes any warranty, expressed or implied, or assumes any legal liability or responsibility for the accuracy, completeness, or usefulness, of any information, apparatus, product, or process disclosed, or represents that its use would not infringe privately owned rights. References herein to any specific commercial product, process, or service by trade name, trade mark, manufacturer, or otherwise, does not necessarily constitute or imply its endorsement, recommendation, or favoring by the U.S. Government or any agency thereof. The views and opinions of authors expressed herein do not necessarily state or reflect those of the U.S. Government or any agency thereof. 
INL/EXT-18-46049

Revision 0

\title{
AGR-3/4 Experiment Preliminary Mass Balance
}

\author{
John D. Stempien \\ Paul A. Demkowicz \\ Jason M. Harp \\ Philip L. Winston
}

August 2018

\begin{abstract}
Idaho National Laboratory
INL ART Program

Idaho Falls, Idaho 83415
\end{abstract}

http://www.inl.gov

Prepared for the

U.S. Department of Energy

Office of Nuclear Energy

Under DOE Idaho Operations Office

Contract DE-AC07-05ID14517 



\title{
INL ART Program \\ AGR-3/4 Experiment Preliminary Mass Balance
}

\author{
INL/EXT-18-46049 \\ Revision 0
}

August 2018

Author:
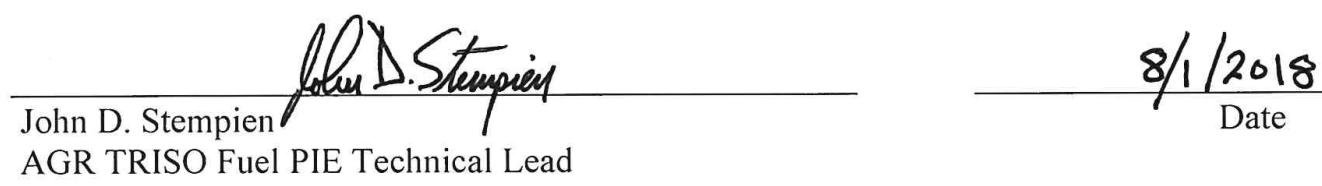

AGR TRISO Fuel PIE Technical Lead

Technical Reviewer: (Confirmation of mathematical accuracy, and correctness of data and appropriateness of assumptions.)

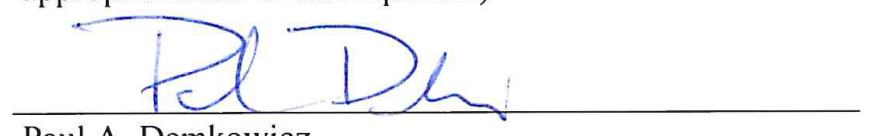

Paul A. Demkowicz

AGR Program Technical Director

Approved by:

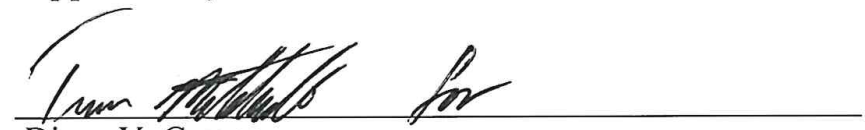

Diane V. Croson

INL ART Deputy Director

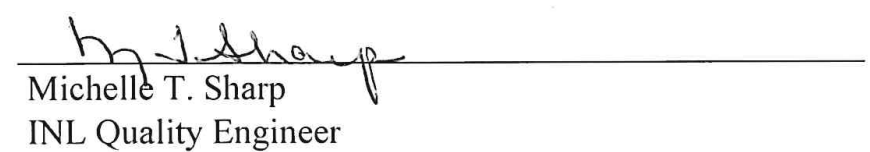

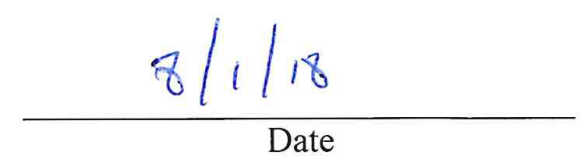
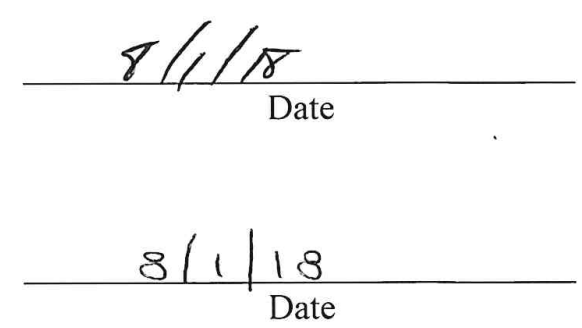



\section{REVISION LOG}

\begin{tabular}{|c|c|c|c|}
\hline Rev. & Date & Affected Pages & Revision Description \\
\hline 0 & $08 / 01 / 2018$ & All & New document. \\
\hline & & & \\
\hline & & & \\
\hline & & & \\
\hline & & & \\
\hline & & & \\
\hline & & & \\
\hline & & & \\
\hline & & & \\
\hline & & & \\
\hline & & & \\
\hline & & & \\
\hline & & & \\
\hline & & & \\
\hline & & & \\
\hline & & & \\
\hline & & & \\
\hline & & & \\
\hline
\end{tabular}





\section{SUMMARY}

AGR-3/4 was an experiment primarily aimed at studying fission product transport in graphite and graphitic materials. To accomplish this, 80 designed-to-fail (DTF) fuel particles coated only with a thin pyrocarbon layer were incorporated among the roughly 7500 tristructural isotropic (TRISO)-coated driver fuel particles in each capsule. It was anticipated that intact DTF particles would behave like TRISO particles with $\mathrm{SiC}$ layer failures (releasing cesium and other metallic fission products to some extent, but retaining fission gases), and failed DTF particles would behave like TRISO particles with failed TRISO coatings (releasing both cesium and other metallic fission products and fission gases). The DTF particles provided a known source of fission products to migrate out into the fuel compact matrix and out into the surrounding concentric rings of graphite and graphitic matrix material for study. Post-irradiation examinations have focused on measuring the total releases of fission products from the fuel compacts (mass balance) and the spatial distribution of fission products in the rings and compacts. The total mass balance is an important parameter for comparison to fission product transport simulations of the AGR-3/4 experiment, and the spatial distribution within carbon rings is being used to derive fission product diffusion coefficients.

To determine the fission product mass balance, each of the 12 irradiation capsules was disassembled, and their component parts analyzed via gamma counting and destructive leach or burn-leach methods. In "standard" capsules (Capsules 1, 3-5, 7-8, 10, and 12), inner rings, outer rings, sink rings, spacers, foils, felts, and through tubes were all analyzed for gamma-emitting fission products. Portions of the inner and outer rings of Capsules 3, 5, 7, and 8, were analyzed for beta-emitting Sr-90, but those data are still being analyzed. "Fuel body" Capsules 2, 6, 9, and 11 were retained intact for future heating tests; thus, the inner and outer rings from these capsules were not measured. The most commonly detected radionuclide fission products were Ag-110m, Cs-134, Cs-137, Eu-154, Eu-155, and Sr-90. Sb-125 was also frequently detected in the sink rings and spacers; however, the zircaloy-4 spacers used in Capsules 1 through 6 contained natural tin that transmuted to $\mathrm{Sb}-125$ and made it impossible to separate $\mathrm{Sb}-125$ released from the fuel from that generated in the spacers.

Summing the fission product inventory measured on each capsule component made it clear that the presence of 80 DTF particles in each capsule resulted in noticeably higher releases of cesium (Cs-134 and Cs-137) from AGR-3/4 fuel when compared to AGR-1 and AGR-2 fuel which did not have DTF particles. Greater than 30 particles worth of cesium was measured outside of the fuel compacts in Capsules 3-5, 7, 8, and 10. In Capsule 11 (an intact fuel body for which the inner and outer rings were not measured), 26 particle equivalents of cesium was measured outside of the outer ring. Based on experience from AGR-1, it is very unlikely that any driver particles failed during the irradiation; therefore, this cesium is assumed to be overwhelmingly dominated by release from DTF particles.

Higher levels of europium and strontium release were also observed in AGR-3/4 when compared to AGR-1 and when compared to most capsules from AGR-2. Tens of particles worth of Eu-154 or Eu-155 were typically measured outside of the fuel compacts (even in fuel body capsules for which the mass balance is incomplete). This is largely due to the DTF particles. Furthermore, it seems that the high irradiation temperature in Capsule 7 (at an average fuel compact temperature of $1345^{\circ} \mathrm{C}$, it is the highest in the AGR program to date) also caused diffusive release of europium from intact driver particles such that the total europium release in Capsule 7 exceeded the inventory in the DTF particles by about a factor of three. This temperature effect was most easily identifiable in Capsule 7, but diffusive release could also have occurred to some extent in other hot capsules such as Capsules 3, 8, and 10.

When analysis of the data from physical sampling of portions of the inner and outer rings of Capsules $3,7,8$, and 10 is complete, a Sr-90 balance for the entirety of those rings can be estimated and added to the Sr-90 balance contributed from components of those capsules. Currently, looking at the incomplete AGR-3/4 Sr-90 balances gives one to two orders of magnitude higher release than the entire in-pile Sr-90 releases from AGR-1. As in the case of europium, this is due substantially to the DTF particles. The high 
irradiation temperature in AGR-3/4 Capsule 7 is likely another contributor to Sr-90 releases in that capsule.

Some correlations between fission product content in the rings and irradiation temperature have been found. For example, Ag- $110 \mathrm{~m}$ release appears to increase sharply at $1100^{\circ} \mathrm{C}$. This is consistent with some observations from post-irradiation heating tests of compacts from AGR-1 and AGR-2. Cesium releases from DTF kernels appear to increase between 900 and $1000^{\circ} \mathrm{C}$. Above $1000^{\circ} \mathrm{C}$ the cesium release varied from about $50 \%$ up to about $100 \%$ of the inventories in the DTF particles. Eu-154 release appear to increase at irradiation temperatures above $1200^{\circ} \mathrm{C}$. The measured sink ring inventories of Ag-110m are exponentially related to the irradiation temperature of the outer ring. The measured sink ring inventories of cesium are linearly related to the irradiation temperature of the outer ring. 


\section{ACKNOWLEDGEMENTS}

The authors gratefully acknowledge the work of Hot Fuel Examination Facility process engineer Cad Christensen on test train disassembly and sorting and transferring of components. Analytical Laboratory staff gamma counted many of the samples and prepared burn-leach samples for Sr-90 analyses. 


\section{CONTENTS}

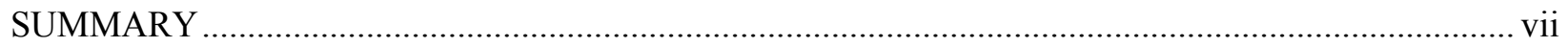

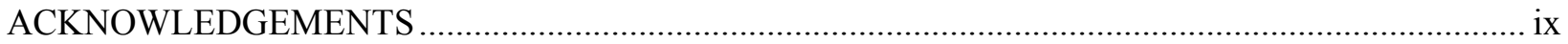

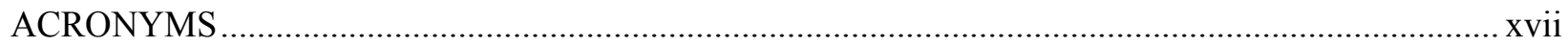

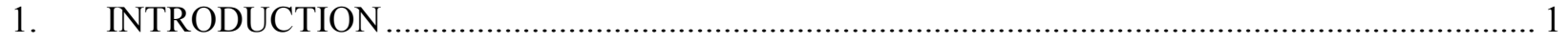

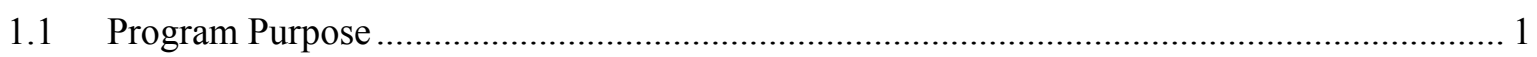

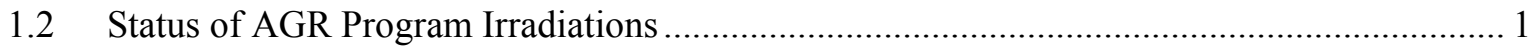

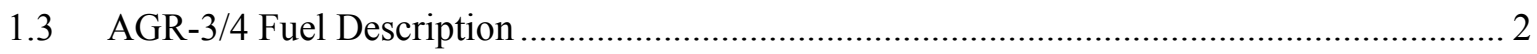

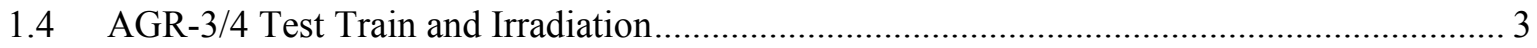

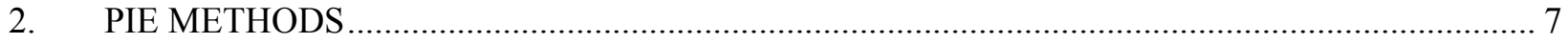

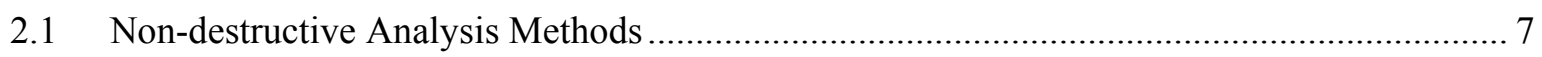

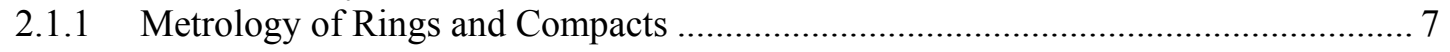

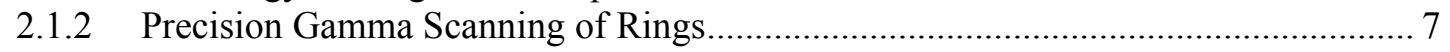

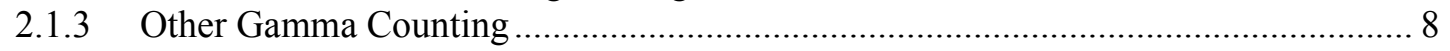

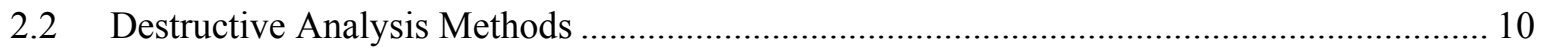

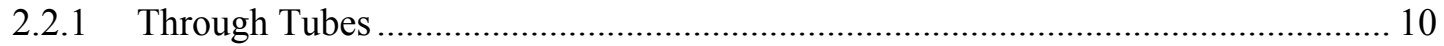

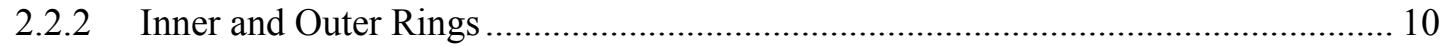

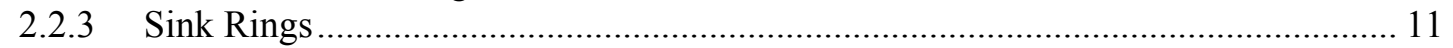

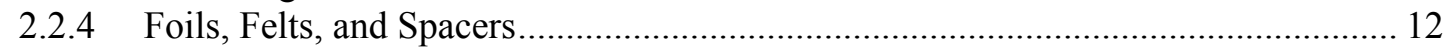

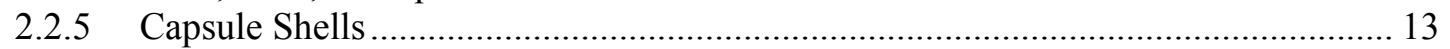

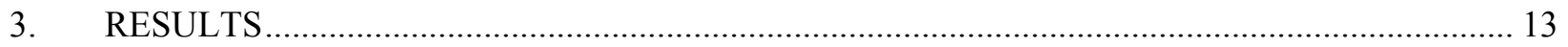

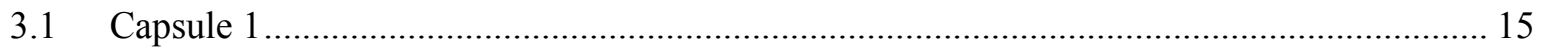

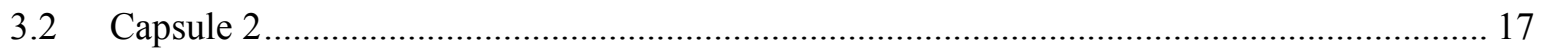

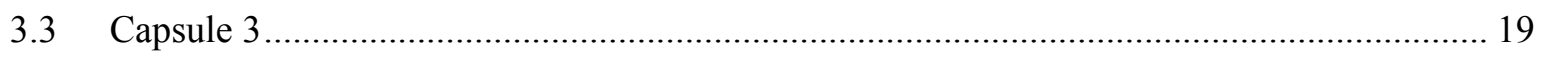

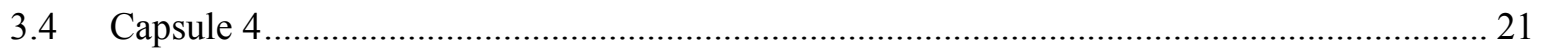

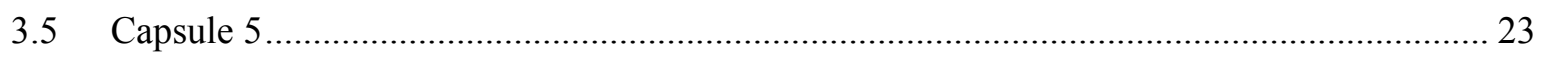

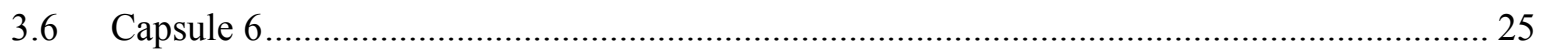

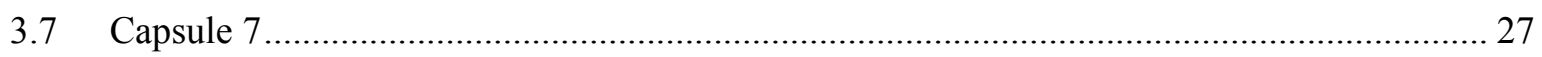

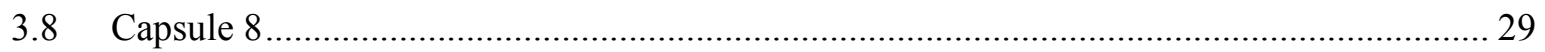

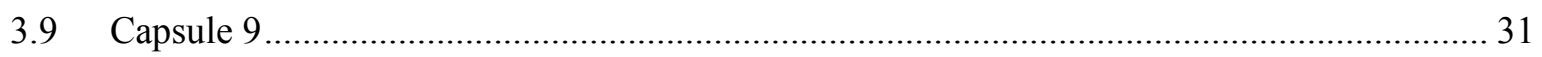

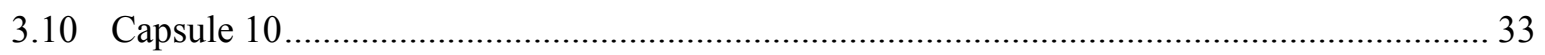

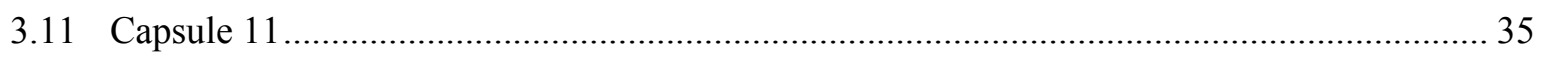

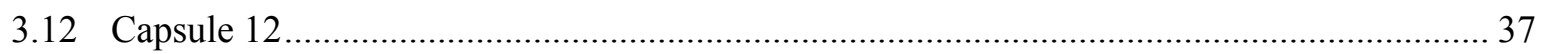

3.13 Summary of Capsule Fission Products Outside of the Fuel................................................. 39

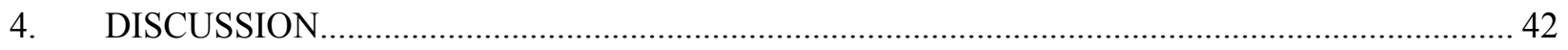

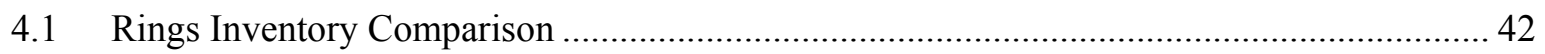

4.2 Ring Inventories Related to Irradiation Temperature .................................................... 44

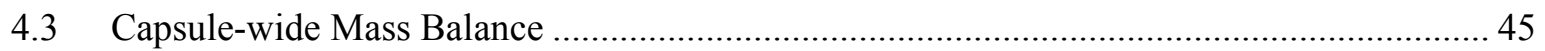

4.3.1 Mass Balance of All Non-Silver Isotopes ............................................................ 45 


\section{FIGURES}

Figure 1. TAVA irradiation temperatures versus burnup for compacts from the AGR-1, AGR-2, and AGR-3/4 irradiations. AGR-1 burnups and temperatures from (Sterbentz 2013) and (Hawkes 2014a), respectively. AGR-2 burnups and temperatures from (Sterbentz 2014) and (Hawkes 2014b), respectively. AGR-3/4 burnups and temperatures from (Sterbentz 2015) and (Hawkes 2016), respectively.

Figure 2. Image of an AGR-3/4 fuel compact (left) and x-ray side view image (right) (Hunn, Trammell, and Montgomery 2011). DTF particles are highlighted with red dots in the $\mathrm{x}$-ray image.

Figure 3. Axial cutaway diagram of a standard AGR-3/4 irradiation capsule. 4

Figure 4. Capsule-averaged TAVA irradiation temperatures for major capsule components from (Hawkes 2016).

Figure 5. Calculated burnup and TAVA temperature for each of the 4 compacts in each of the 12 AGR 3/4 capsules. Temperatures and burnups from (Hawkes 2016) and (Sterbentz 2015), respectively.

Figure 6. Gamma spectrometry system in Hot Cell 4 at the AL. (The can roller used for sink ring counting is not pictured).

Figure 7. 7.57 L (2 gallon) can on roller in line with Hot Cell 4 spectrometer.

Figure 8. Equipment used for physical ring sampling. End mill (left) and cyclone separator (right).

Figure 9. Sink Ring 7 prior to oxidation (left). Ash remaining after Sink Ring 7 oxidation (right).

Figure 10. Inner, outer, and sink ring Ag-110m capsule fractions. Bars with patterned fill are based on MDAs.

Figure 11. Inner, outer, and sink ring Cs-134 capsule fractions. The bar with patterned fill is based on an MDA.

Figure 12. Inner, outer, and sink ring Eu-154 capsule fractions. Bars with patterned fill are based on MDAs.

Figure 13. Sink ring Ag-110m inventories versus outer ring TAVA temperatures.

Figure 14. Sink ring Cs-134 inventories versus outer ring TAVA temperatures.

Figure 15. Total fraction of Cs-134 and Eu-154 measured outside of the fuel in all standard-type capsules. "Low" values are measured values only (no values derived from MDAs). "High" values are the low values plus MDAs from instances where a given isotope was not detected. NOTE: Sr-90 is not a complete balance because inner and outer rings require destructive analysis for measurement. 
Figure 16. Ag-110m measured-to-calculated ratios versus compact TAVA irradiation temperature.

Figure 17. Fraction of predicted Ag-110m on all capsule components including compacts. Here, if no Ag-110m was detect, a value was determined based on MDAs and included in the plot. Across the top of each column is the total fraction from the sum of all components in each capsule.

Figure 18. Fraction of predicted Ag-110m measured on all capsule components including compacts. Here, if no Ag-110m was detect, the Ag-110m value for that component was zero. Across the top of each column is the total fraction from the sum of all components in each capsule.

\section{TABLES}

Table 1. AGR-3/4 capsule types, ring materials, and ring dimensions from PIE. Dimensions from (Stempien et al. 2016). Complete dimensions and uncertainties are in (Stempien et al. 2016).

Table 2. AGR-3/4 estimated DTF particle failure count in each irradiation capsule. There were 4 compacts in each capsule, and each compact had 20 DTF particles. Table values from (Collin et al. 2018).

Table 3. Summary of AGR-3/4 ring PGS scans.

Table 4. Summary of major isotopes in Capsule 1 hardware. Shaded cells are based entirely on MDAs or cases where MDAs account for $>50 \%$ of a sum of MDAs and measured values.

Table 5. Inventories in capsule rings, total hardware inventories (sum from Table 4), and total inventory measured outside of the fuel (Grand Totals). Errors are given based on propagation of uncertainty across the sum of all measured values. Shaded cells are based entirely on MDAs or cases where MDAs account for $>50 \%$ of a sum of MDAs and measured values.

Table 6. Summary of major isotopes on Capsule 2 hardware. Shaded cells are based entirely on MDAs or cases where MDAs account for $>50 \%$ of a sum of MDAs and measured values.

Table 8. Summary of inventories of select isotopes on Capsule 3 hardware. Shaded cells are based entirely on MDAs or cases where MDAs account for $>50 \%$ of a sum of MDAs and measured values.

Table 9. Inventories in capsule rings, total hardware (sum from Table 8), and total inventory measured outside of the fuel. Errors are given based on propagation of uncertainty across all the sum of all measured values. Shaded cells are based entirely on MDAs or cases where MDAs account for $>50 \%$ of a sum of MDAs and measured values.

Table 10. Summary of inventories of select isotopes on Capsule 4 hardware. Shaded cells are based entirely on MDAs or cases where MDAs account for $>50 \%$ of a sum of MDAs and measured values.

Table 11. Inventories in capsule rings, total hardware (sum from Table 10), and total inventory measured outside of the fuel. Errors are given based on propagation of uncertainty 
across all the sum of all measured values. Shaded cells are based entirely on MDAs or cases where MDAs account for $>50 \%$ of a sum of MDAs and measured values.

Table 12. Summary of inventories of select isotopes on Capsule 5 hardware. Shaded cells are based entirely on MDAs or cases where MDAs account for $>50 \%$ of a sum of MDAs and measured values.

Table 13. Inventories in capsule rings, total hardware (Total of measured + MDA from Table 12), and total inventory measured outside of the fuel ("Grand Total measured + MDA" and "Grand Total measured only"). Errors are given based on propagation of uncertainty across the sum of all measured values. Shaded cells are based entirely on MDAs or cases where MDAs account for $>50 \%$ of a sum of MDAs and measured values.

Table 14. Summary of inventories of select isotopes on Capsule 6 hardware. Shaded cells are based entirely on MDAs or cases where MDAs account for $>50 \%$ of a sum of MDAs and measured values.

Table 15. Inventories in sink ring, total hardware (Total of measured + MDA from Table 14), and available inventory measured outside of the fuel ("Grand Total measured + MDA" and "Grand Total measured only"). Inner and outer rings not measured because Capsule 6 is an intact fuel body. Errors are given based on propagation of uncertainty across the sum of all measured values. Shaded cells are based entirely on MDAs or cases where MDAs account for $>50 \%$ of a sum of MDAs and measured values.

Table 16. Summary of inventories of select isotopes on Capsule 7 hardware. Shaded cells are based entirely on MDAs or cases where MDAs account for $>50 \%$ of a sum of MDAs and measured values.

Table 17. Inventories in capsule rings, total hardware (Total of measured + MDA from Table 16), and total inventory measured outside of the fuel ("Grand Total measured + MDA" and "Grand Total measured only"). Errors are given based on propagation of uncertainty across the sum of all measured values. Shaded cells are based entirely on MDAs or cases where MDAs account for $>50 \%$ of a sum of MDAs and measured values.

Table 18. Summary of inventories of select isotopes on Capsule 8 hardware. Shaded cells are based entirely on MDAs or cases where MDAs account for $>50 \%$ of a sum of MDAs and measured values.

Table 19. Inventories in capsule rings, total hardware (Total of measured + MDA from Table 18), and total inventory measured outside of the fuel ("Grand Total measured + MDA" and "Grand Total measured only"). Errors are given based on propagation of uncertainty across the sum of all measured values. Shaded cells are based entirely on MDAs or cases where MDAs account for $>50 \%$ of a sum of MDAs and measured values.

Table 20. Summary of inventories of select isotopes on Capsule 9 hardware. Shaded cells are based entirely on MDAs or cases where MDAs account for $>50 \%$ of a sum of MDAs and measured values.

Table 21. Inventories in capsule rings, total hardware (Total of measured + MDA from Table 20), and available inventory measured outside of the fuel ("Grand Total measured + MDA" and "Grand Total measured only"). Capsule 9 is an intact fuel body. Inner and outer rings were not measured. Errors are given based on propagation of uncertainty across the sum of all measured values. Shaded cells are based entirely on MDAs or cases where MDAs account for $>50 \%$ of a sum of MDAs and measured values. 
Table 22. Summary of inventories of select isotopes on Capsule 10 hardware. Shaded cells are based entirely on MDAs or cases where MDAs account for $>50 \%$ of a sum of MDAs and measured values.

Table 23. Inventories in capsule rings, total hardware (Total of measured + MDA from Table 22), and total inventory measured outside of the fuel ("Grand Total measured + MDA" and "Grand Total measured only"). Errors are given based on propagation of uncertainty across the sum of all measured values. Shaded cells are based entirely on MDAs or cases where MDAs account for $>50 \%$ of a sum of MDAs and measured values.

Table 24. Summary of inventories of select isotopes on Capsule 11 hardware. Shaded cells are based entirely on MDAs or cases where MDAs account for $>50 \%$ of a sum of MDAs and measured values.

Table 25. Inventories in sink ring, hardware (Total of measured + MDA from Table 24), and available inventory measured outside of the fuel ("Grand total measured + MDA" and "Grand total measured only"). Inner and outer rings not measured. Errors are given based on propagation of uncertainty across the sum of all measured values. Shaded cells are based entirely on MDAs or cases where MDAs account for $>50 \%$ of a sum of MDAs and measured values. .36

Table 26. Summary of inventories of select isotopes on Capsule 12 hardware. Shaded cells are based entirely on MDAs or cases where MDAs account for $>50 \%$ of a sum of MDAs and measured values.

Table 27. Inventories in capsule rings, hardware (Total of measured + MDA from Table 26), and total inventory measured outside of the fuel ("Grand total measured + MDA" and "Grand total measured only"). Errors are given based on propagation of uncertainty across the sum of all measured values. Shaded cells are based entirely on MDAs or cases where MDAs account for $>50 \%$ of a sum of MDAs and measured values.

Table 28. Summary of total fission product fractions outside of the fuel in each capsule. "Low" includes measured values only. "High" represents measured values plus fractions calculated from MDAs.

Table 29. Summary of the fission product inventory measured outside of the fuel expressed units of particle equivalents. "Low" includes measured values only. "High" represents measured values plus particle equivalents calculated from MDAs.

Table 30. Total percent error (+/-) of the total measured fraction of fission products outside of the fuel (corresponding to the "low" rows in Table 28 and Table 29). Blank cells indicate no activity was measured..... 


\section{ACRONYMS}

AGR Advanced Gas Reactor

AL Analytical Laboratory

ART Advanced Reactor Technologies

ATR Advanced Test Reactor

DAW Dry Active Waste

DLBL deconsolidation leach-burn-leach

DTF designed-to-fail

FB fuel body

FIMA fissions per initial heavy metal atom

GECT gamma emission computed tomography

HFEF Hot Fuel Examination Facility

HOGS HFEF out-of-cell gamma station

HTGR high temperature gas-cooled reactor

ICP-MS inductively-coupled plasma mass spectrometry

INL Idaho National Laboratory

IPyC inner pyrolytic carbon

$\mathrm{M} / \mathrm{C}$ measured-to-calculated ratio

MDA minimum detectable activity

OPyC outer pyrolytic carbon

ORNL Oak Ridge National Laboratory

PGS Precision Gamma Scanner

PIE post-irradiation examination

R-DLBL radial deconsolidation leach-burn-leach

$\mathrm{SiC} \quad$ silicon carbide

TAVA time-averaged volume-averaged

TRISO tristructural isotropic

UCO uranium oxycarbide 
xviii 


\section{AGR-3/4 Experiment Preliminary Mass Balance}

\section{INTRODUCTION \\ 1.1 Program Purpose}

The Advanced Gas Reactor (AGR) Fuel Development and Qualification Program was established to perform research and development on tristructural isotropic (TRISO)-coated particle fuel to support deployment of a high-temperature gas-cooled reactor (HTGR). This work continues as part of the Advanced Reactor Technologies (ART) TRISO Fuel Program. The overarching goal of the ART AGR program is to provide a baseline fuel qualification data set to support licensing and operation of an HTGR. To achieve these goals, the program includes the elements of fuel fabrication, irradiation, post-irradiation examination (PIE) and safety/heating testing, fuel performance modeling, and fission product transport (INL 2017). Several fuel irradiation experiments have been performed at the Advanced Test Reactor (ATR) at Idaho National Laboratory (INL), and a fourth irradiation began in February 2018. These experiments are intended to provide data on fuel performance under irradiation, support fuel fabrication process development, qualify fuel for operating and accident conditions, provide irradiated fuel for accident testing, and support development of fuel performance and fission product transport models.

\subsection{Status of AGR Program Irradiations}

The first two AGR fuel irradiation experiments (AGR-1 and AGR-2) had similar test train designs, and one objective was to test uranium oxycarbide (UCO) TRISO-coated particle fuel performance over a range of irradiation temperatures and burnups. The UCO fuel kernels are a heterogeneous mixture of uranium carbide and uranium oxide. Figure 1 shows the time-averaged, volume-averaged (TAVA) irradiation temperature and burnup for each AGR-1 and AGR-2 fuel compact. Burnup is given as percent fissions per initial metal atom (FIMA). AGR-2 TRISO coatings were fabricated using conditions derived from the AGR-1 Variant 3 fuel, and while the AGR-1 coatings were produced at the lab-scale, AGR-2 coatings were produced in a large, industrial-scale coater (Demkowicz 2013, INL 2017).

In addition to AGR UCO fuel (in Capsules 2, 5, and 6), the AGR-2 experiment also had $\mathrm{UO}_{2}$ fuel (in Capsule 3) to compare the performance of $\mathrm{UCO}$ versus $\mathrm{UO}_{2}$ fuel and to compare to $\mathrm{UO}_{2}$ fuel performance observed historically in the German TRISO fuel program. ${ }^{a}$ AGR-1 was irradiated in the B-10 position in ATR from December 2006 to November 2009 (Collin 2015a). AGR-2 was irradiated in the B-12 position of ATR from June 2010 to October 2013 (Collin 2014). The major elements of AGR-1 PIE are complete (Demkowicz et al. 2015a). AGR-2 PIE began in July 2014, is still in-progress, and encompasses asirradiated analyses, reirradiations, heating testing, microscopy, and other activities.

The third irradiation experiment, AGR-3/4, was designed to investigate the migration of fission products in fuel compact graphitic matrix and reactor graphite components. Figure 1 shows that AGR-3/4 spanned a burnup range from approximately 4.8 to $15.25 \%$ FIMA and compact TAVA irradiation temperatures from approximately 830 to $1375^{\circ} \mathrm{C}$. AGR-3/4 was irradiated in the northeast flux trap of ATR, from December 2011 to April 2014 (Collin 2015b). The experiment consisted of fuel compacts containing TRISO-coated driver-fuel particles similar to AGR-1 baseline fuel (Collin 2015b; Hunn and Lowden 2007; Hunn et al. 2014) and designed-to-fail (DTF) particles that are designed to release fission products during irradiation, which will migrate through the surrounding cylindrical rings of graphitic matrix and nuclear-grade graphite. Following irradiation, PIE measurements of the fission product distributions in these rings and fuel compacts are critical components of the experiment. PIE will provide data that will support refinement of fission product transport models and HTGR source-term analyses

The AGR-2 irradiation had 6 irradiation capsules. Capsules 2, 3, 5, and 6 were US AGR capsules. Capsules 1 and 4 were French and South African fuel, respectively (Collin 2014). Capsule 1 and 4 fuel compacts are not shown in Figure 1. 
(Demkowicz 2017). The fourth irradiation experiment, AGR-5/6/7 (Collin 2018), started in ATR in February 2018 and serves as the fuel qualification irradiation.

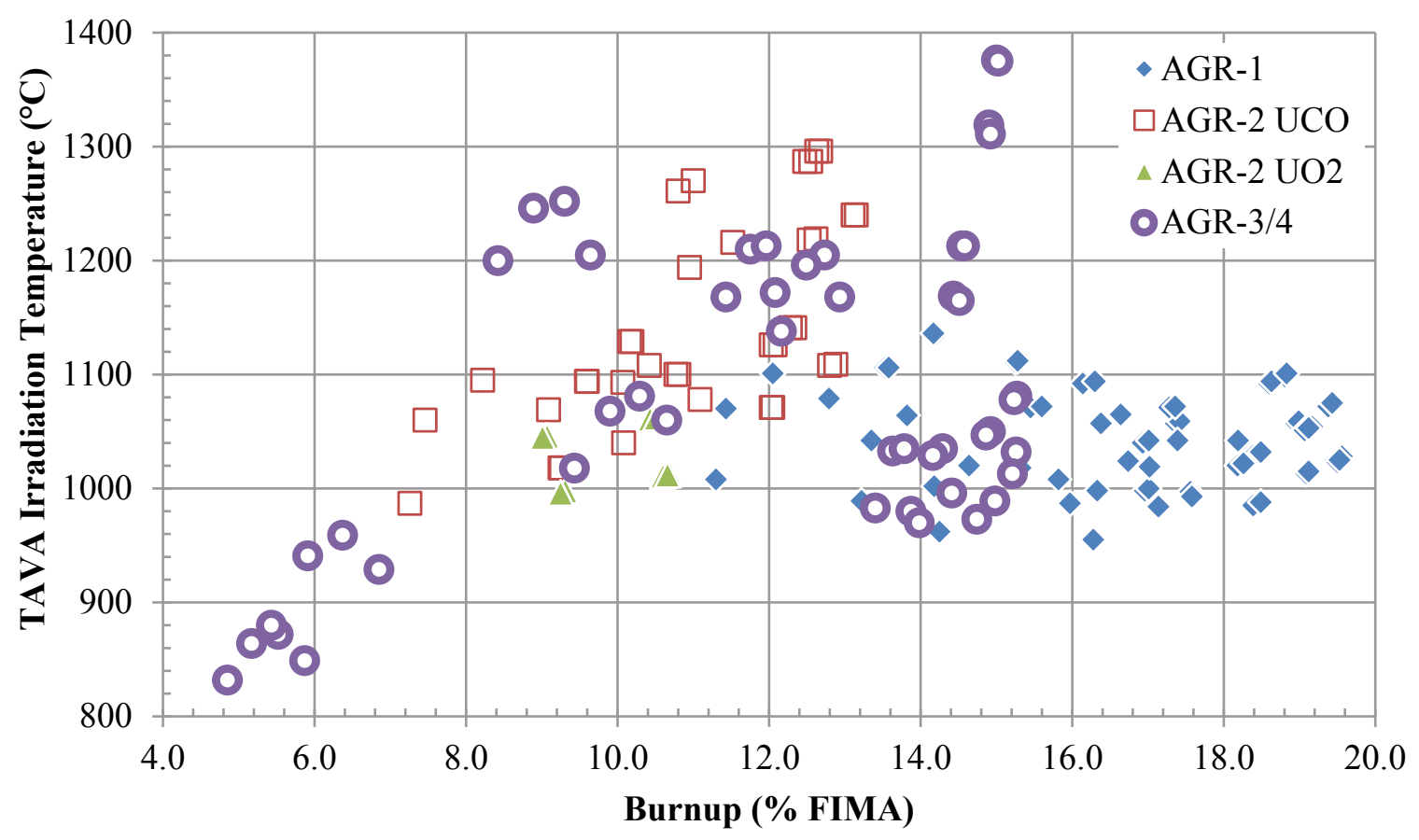

Figure 1. TAVA irradiation temperatures versus burnup for compacts from the AGR-1, AGR-2, and AGR-3/4 irradiations. AGR-1 burnups and temperatures from (Sterbentz 2013) and (Hawkes 2014a), respectively. AGR-2 burnups and temperatures from (Sterbentz 2014) and (Hawkes 2014b), respectively. AGR-3/4 burnups and temperatures from (Sterbentz 2015) and (Hawkes 2016), respectively.

\subsection{AGR-3/4 Fuel Description}

A feature of AGR-3/4 fuel that set it apart from AGR-1 and AGR-2 was the incorporation of 20 DTF particles in each compact, in addition to the approximately 1872 TRISO-coated "driver" fuel particles. DTF fuel kernels were coated only with a thin $(20-\mu \mathrm{m}$-thick) pyrocarbon layer. This layer was intentionally fabricated with a high anisotropy, such that it would be likely to fail during the irradiation (Collin 2015b; Hunn and Miller 2009; and Kercher et al. 2011), resulting in up to 20 exposed fuel kernels per compact. As shown at right in Figure 2, the DTF particles (highlighted in red) were aligned roughly along the compact radial centerline. DTF particles provided a known source of fission products to migrate radially outward in the compacts and into the surrounding concentric rings of graphite and/or matrix material.

The white particles in Figure 2 are the driver particles. Driver particle fuel kernels were fully TRISO-coated with buffer layer, inner pyrolytic carbon layer (IPyC), silicon carbide layer (SiC), and outer pyrolytic carbon layer (OPyC) characteristics similar to the "baseline" variant from the AGR-1 experiment (Collin 2015c; Hunn and Lowden 2007). Both the AGR-3/4 driver and DTF fuel particles contain UCO fuel kernels (approximately $350 \mu \mathrm{m}$ in diameter) manufactured at BWX Technologies Nuclear Operations Group (Lynchburg, VA). The U-235 enrichment was $19.7 \mathrm{wt} \%$. The DTF pyrocarbon coating and the driver fuel TRISO coatings were applied to the kernels by Oak Ridge National Laboratory (ORNL). Driver particle and DTF particle properties are summarized in (Collin 2015b). Complete kernel and particle characterization and fabrication data are compiled in 
(Kercher and Hunn 2006; Hunn and Lowden 2007; Hunn and Miller 2009; Kercher et al., 2011). Driver fuel TRISO coatings had the following average layer thicknesses:

Buffer: $109.7 \mu \mathrm{m}$

IPyC: $40.4 \mu \mathrm{m}$

SiC: $33.5 \mu \mathrm{m}$

OPyC: $41.3 \mu \mathrm{m}$.

AGR-3/4 driver and DTF particles were over-coated and formed into cylindrical fuel compacts at ORNL. The compact graphitic matrix material is composed of multiple types of graphite and a carbonized phenolic resin. Compacts were nominally $12.3 \mathrm{~mm}$ in diameter and $12.5 \mathrm{~mm}$ long (in contrast to the AGR-1 and AGR-2 compacts, which were approximately $12.3 \mathrm{~mm}$ in diameter and $25 \mathrm{~mm}$ long). A summary of AGR-3/4 fuel properties are provided in the AGR-3/4 Final As-Run Report (Collin 2015b). Detailed characterization data of the as-fabricated compacts has been compiled in (Hunn, Trammel, and Montgomery 2011).
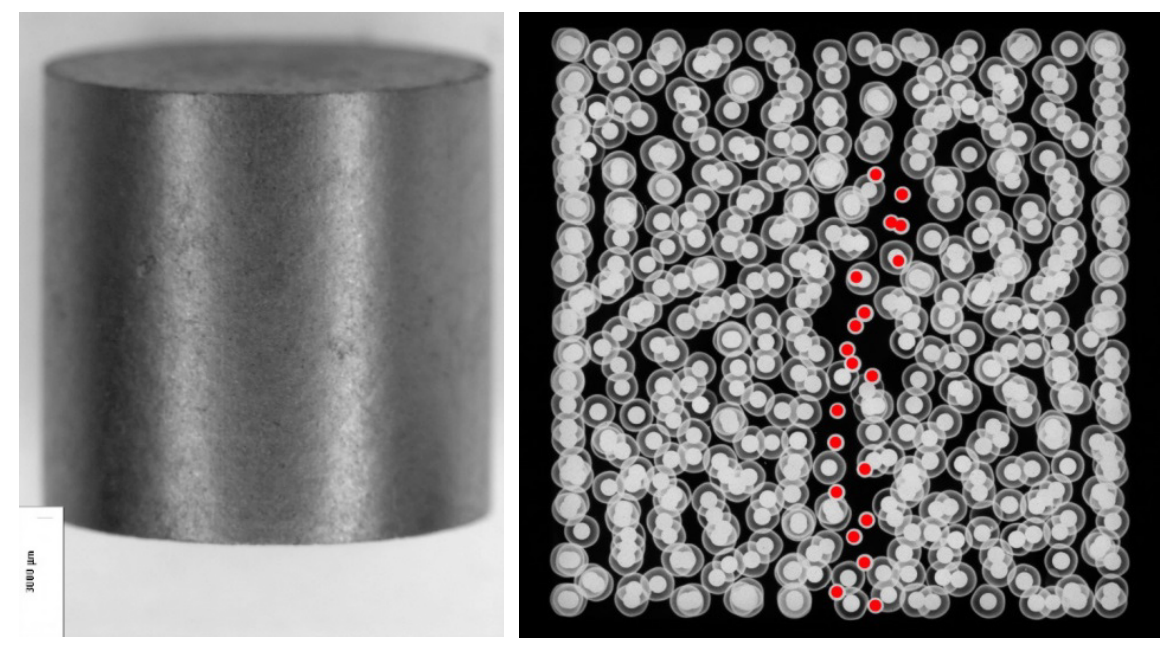

Figure 2. Image of an AGR-3/4 fuel compact (left) and x-ray side view image (right) (Hunn, Trammell, and Montgomery 2011). DTF particles are highlighted with red dots in the x-ray image.

\subsection{AGR-3/4 Test Train and Irradiation}

The AGR-3/4 irradiation test train consisted of 12 capsules, numbered 1 through 12 from the bottom to the top of the ATR core. Each capsule contained 4 fuel compacts. Figure 3 shows a cross section of an AGR-3/4 irradiation capsule. The compacts were stacked vertically in the center of concentric rings of graphitic matrix material and/or structural graphite (IG-110 and PCEA). The matrix rings were fabricated at ORNL using an A3-27 formulation. 


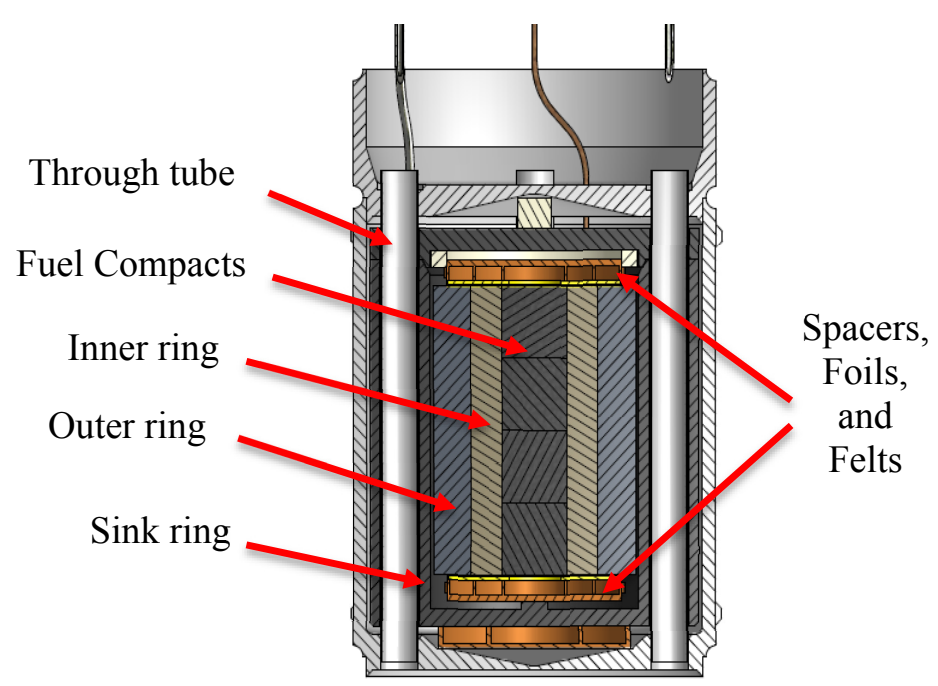

Figure 3. Axial cutaway diagram of a standard AGR-3/4 irradiation capsule.

Table 1 lists the materials, types of capsules, and PIE measurement diameters for each of the rings. There were two types of capsules: "standard" and "fuel body" (FB). The standard capsule type is depicted in Figure 3 where the outer ring is open on its top and bottom. Fuel bodies, on the other hand, had floors and a lid that screwed on to the top of the outer ring. Each capsule also included several small spacers of various materials (graphite, zirconia, or zircaloy-4) and graphite foils to separate components and act as thermal barriers to control temperature in the compacts. Compact lengths were measured as part of PIE, but ring lengths were not measured. All inner rings had as-fabricated lengths of $50.8 \mathrm{~mm}$ (2.0 in). In standard capsules, outer ring lengths were $50.8 \mathrm{~mm}$ (2.0 in). In fuel bodies, the outer rings had a sealed bottom and a lid for a total overall length of about $61.0 \mathrm{~mm}(2.4 \mathrm{in})$. Sink ring lengths were generally about $63.5 \mathrm{~mm}$ (2.5 in); however, some sink rings were about $71.1 \mathrm{~mm}$ ( $2.8 \mathrm{in})$ long. All sink rings had lids and sealed bottoms.

Figure 4 summarizes the TAVA irradiation temperature for each major component (fuel compacts, inner, outer, and sink rings) within each capsule. Sink rings were intentionally cold to act as a sink to stop further radial transport of fission products during the experiment. In Figure 4, the compact temperature that is plotted was averaged over the 4 compacts in a given capsule. The burnup and TAVA temperature for each individual compact is given in Figure 5.

Table 1. AGR-3/4 capsule types, ring materials, and ring dimensions from PIE. Dimensions from (Stempien et al. 2016). Complete dimensions and uncertainties are in (Stempien et al. 2016).

\begin{tabular}{|c|c|c|c|c|c|c|c|c|c|c|}
\hline \multirow{2}{*}{$\begin{array}{c}\text { Capsule } \\
\text { No. } \\
\end{array}$} & \multirow{2}{*}{$\begin{array}{c}\text { Capsule } \\
\text { Type } \\
\end{array}$} & \multicolumn{3}{|c|}{ Ring Material } & \multicolumn{2}{|c|}{$\begin{array}{c}\text { Inner Ring } \\
\text { Diameters (mm) }\end{array}$} & \multicolumn{2}{|c|}{$\begin{array}{c}\text { Outer Ring } \\
\text { Diameters } \\
(\mathrm{mm})\end{array}$} & \multicolumn{2}{|c|}{$\begin{array}{c}\text { Sink Ring } \\
\text { Diameters } \\
(\mathrm{mm})\end{array}$} \\
\hline & & Inner & Outer & Sink & ID & OD & ID & OD & ID & OD \\
\hline 1 & Std & Matrix & PCEA & PCEA & 12.55 & 23.61 & 24.53 & 33.50 & 41.21 & 61.59 \\
\hline 2 & FB & Matrix & PCEA & PCEA & $\mathrm{N} / \mathrm{A}$ & N/A & $\mathrm{N} / \mathrm{A}$ & 36.72 & 39.33 & 62.05 \\
\hline 3 & Std & PCEA & PCEA & PCEA & 12.62 & 24.03 & 24.86 & 33.08 & 41.42 & 63.56 \\
\hline 4 & FB & Matrix & PCEA & PCEA & 12.71 & 23.87 & 24.70 & 39.24 & 39.48 & 63.32 \\
\hline 5 & Std & Matrix & PCEA & PCEA & 12.67 & 23.89 & 24.68 & 39.39 & 39.54 & 63.61 \\
\hline 6 & FB & Matrix & PCEA & PCEA & N/A & N/A & N/A & 39.33 & 39.48 & 63.30 \\
\hline 7 & Std & Matrix & PCEA & PCEA & 12.75 & 23.67 & 24.93 & 37.35 & 39.53 & 63.63 \\
\hline 8 & Std & IG-110 & IG-110 & PCEA & 12.60 & 24.07 & 24.77 & 38.55 & 39.57 & 63.64 \\
\hline
\end{tabular}


Table 1. (continued).

\begin{tabular}{|c|c|c|c|c|c|c|c|c|c|c|}
\hline \multirow{2}{*}{$\begin{array}{c}\text { Capsule } \\
\text { No. }\end{array}$} & \multirow{2}{*}{$\begin{array}{c}\text { Capsule } \\
\text { Type }\end{array}$} & \multicolumn{3}{|c|}{ Ring Material } & \multicolumn{2}{|c|}{$\begin{array}{c}\text { Inner Ring } \\
\text { Diameters (mm) }\end{array}$} & \multicolumn{2}{|c|}{$\begin{array}{c}\text { Outer Ring } \\
\text { Diameters } \\
(\mathbf{m m})\end{array}$} & \multicolumn{2}{|c|}{$\begin{array}{c}\text { Sink Ring } \\
\text { Diameters } \\
(\mathrm{mm})\end{array}$} \\
\hline & & Inner & Outer & Sink & ID & OD & ID & OD & ID & OD \\
\hline 9 & $\mathrm{FB}$ & Matrix & IG-110 & PCEA & N/A & N/A & N/A & 39.27 & 39.46 & 63.08 \\
\hline 10 & Std & PCEA & PCEA & PCEA & 12.58 & 24.04 & 24.83 & 37.48 & 39.40 & 63.43 \\
\hline 11 & FB & Matrix & PCEA & PCEA & $\mathrm{N} / \mathrm{A}$ & N/A & $\mathrm{N} / \mathrm{A}$ & 33.29 & $\mathrm{~N} / \mathrm{A}$ & $\mathrm{N} / \mathrm{A}$ \\
\hline 12 & Std & Matrix & PCEA & PCEA & 12.47 & 24.23 & 24.51 & 34.98 & 39.34 & 61.60 \\
\hline
\end{tabular}

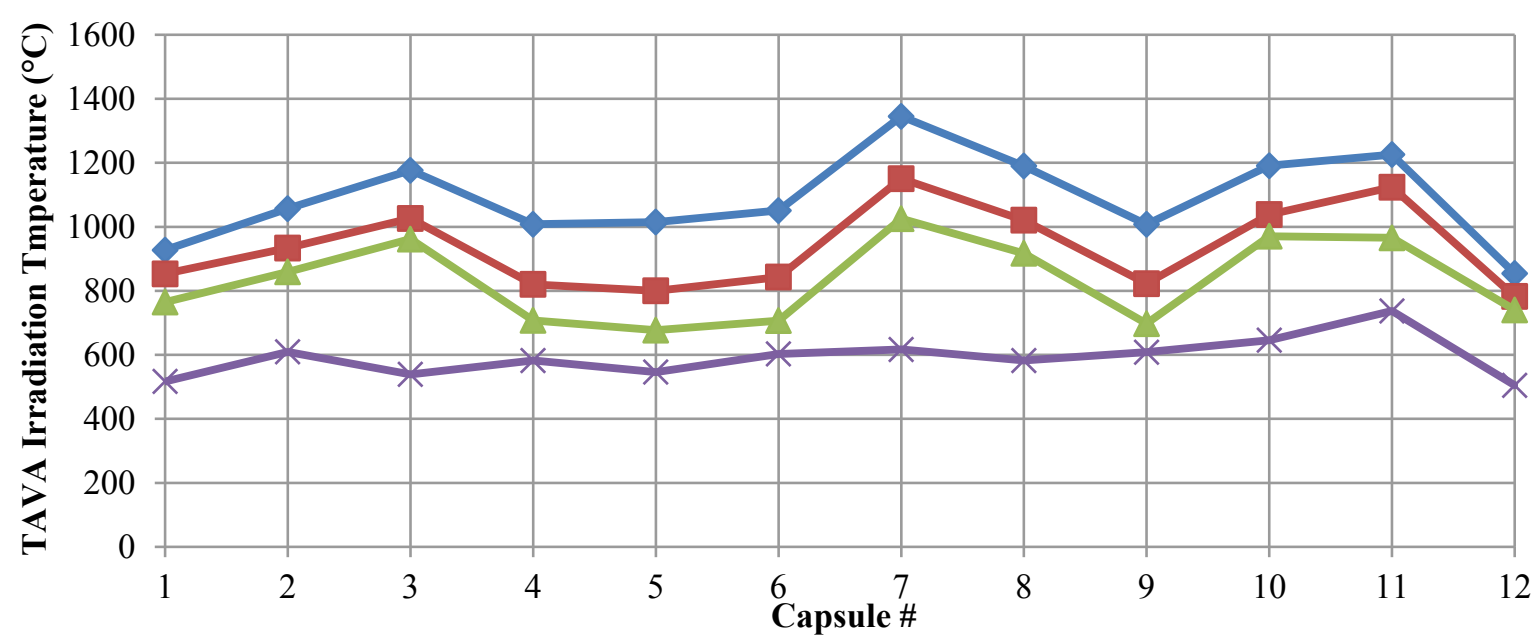

$\leadsto$ Compacts $\quad \leftarrow$ - Inner Ring $\quad$ Outer Ring $\quad$ Sink Ring

Figure 4. Capsule-averaged TAVA irradiation temperatures for major capsule components from (Hawkes 2016).

Figure 5 shows the TAVA irradiation temperature and burnup for all 4 compacts in all 12 AGR 3/4 irradiation capsules. In the $\mathrm{X}-\mathrm{Y}$ compact naming convention, $\mathrm{X}$ denotes the capsule number, and $\mathrm{Y}$ denotes the level of the compact within the capsule (with level 1 at the bottom and level 4 at the top of the capsule). For example, Compact 3-3 is the third compact from the bottom of Capsule 3, and Compact 12-1 is the bottom compact from Capsule 12 .

Each capsule had its own gas line, and a sweep gas carried fission gases to gamma detectors. Fission gas measurements taken during the AGR-3/4 irradiation, and release-to-birth ratio analysis enabled estimates of the number of in-pile DTF particle failures per irradiation capsule (Collin et al. 2018). These estimates are listed in Table 2. Based on experience from AGR-1, it is very unlikely that any driver particles failed during the irradiation; therefore, all supposed in-pile particle failures are assumed to be DTF failures. 
Since there are only 80 DTF particles per capsule, a combination of measurement uncertainty and calculational biases in the physics analyses may explain why the total "best estimate" value for the number of DTF failures differs from 80. If it were assumed that each compact within a capsule had the same number of DTF failures, then the number of DTF particle failures per compact is simply the estimated number of failures divided by 4 . At the moment, there is no evidence that each compact within a capsule has the exact same number of DTF failures. However, compact cross-section analysis via optical microscopy observed roughly half of all the DTF particles in 3 compacts, and all of the DTF particles observed had failed pyrocarbon layers, suggesting the possibility that all DTF particles failed inpile.

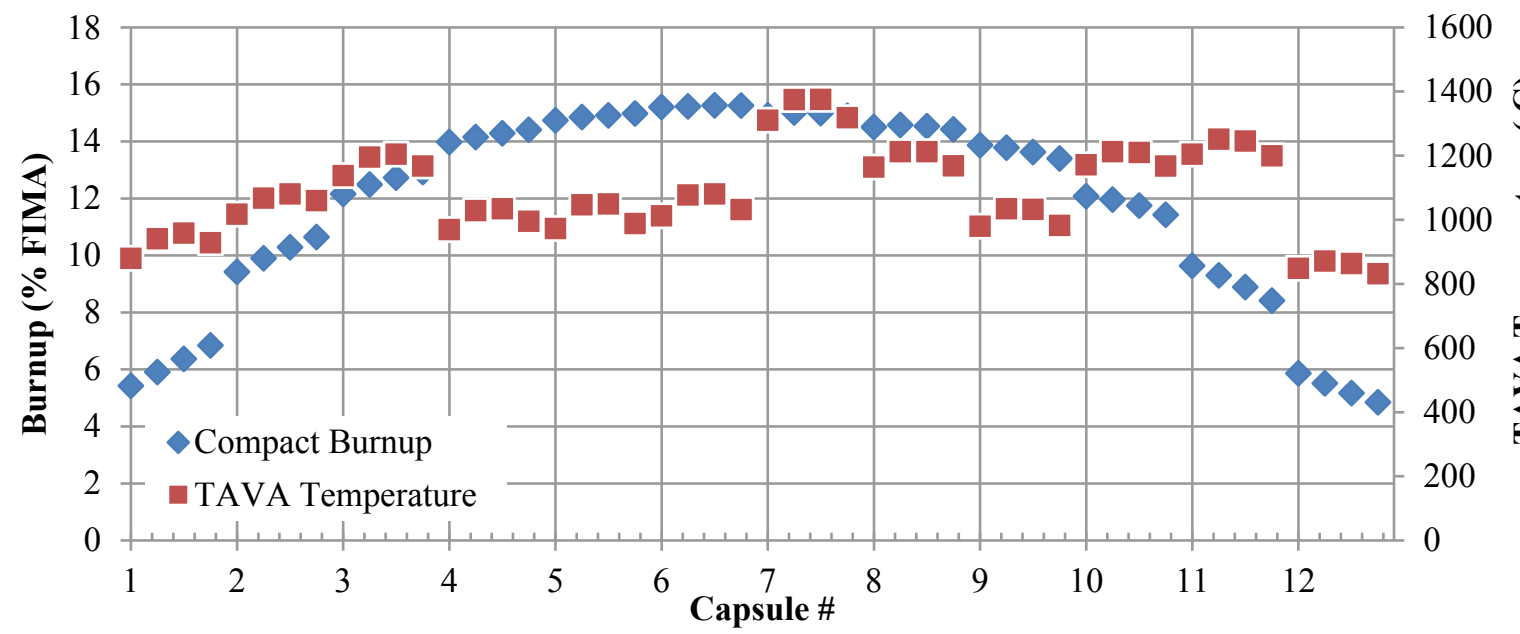

Figure 5. Calculated burnup and TAVA temperature for each of the 4 compacts in each of the 12 AGR 3/4 capsules. Temperatures and burnups from (Hawkes 2016) and (Sterbentz 2015), respectively.

Table 2. AGR-3/4 estimated DTF particle failure count in each irradiation capsule. There were 4 compacts in each capsule, and each compact had 20 DTF particles. Table values from (Collin et al. 2018).

\begin{tabular}{|c|c|c|c|}
\hline Capsule & Minimum Estimate & Best Estimate & Maximum Estimate \\
\hline 1 & 21 & 41 & 81 \\
\hline 2 & 51 & 91 & 168 \\
\hline 3 & 53 & 96 & 164 \\
\hline 4 & 57 & 76 & 100 \\
\hline 5 & 36 & 54 & 92 \\
\hline 6 & 42 & 47 & 53 \\
\hline 7 & 38 & 52 & 75 \\
\hline 8 & 54 & 78 & 129 \\
\hline 9 & 88 & 90 & 99 \\
\hline 10 & 36 & 47 & 75 \\
\hline 11 & 48 & 69 & 92 \\
\hline 12 & 38 & 39 & 49 \\
\hline
\end{tabular}




\section{PIE METHODS}

AGR-3/4 PIE activities are aimed at measuring the fission product inventories of each component of the irradiation test train, determining the spatial distribution of fission products in order to compare with predictive models (Humrickhouse et al. 2016), and determining transport parameters (e.g., fission product diffusion coefficients) in graphite and graphitic materials. All components shown in Figure 3 were analyzed for fission products. These analyses took place either at the Analytical Laboratory (AL) at the Materials and Fuels Complex or at the Hot Fuels Examination Facility (HFEF) also at the Materials and Fuels Complex. Appendix A lists the AL report numbers associated with these analyses.

\subsection{Non-destructive Analysis Methods}

\subsubsection{Metrology of Rings and Compacts}

At the completion of the irradiation in ATR, all irradiation capsules were disassembled (Demkowicz 2017). Components from all standard body capsules were separated, and dimensional measurements were taken of the rings and compacts (Stempien et al. 2016). Of the fuel bodies, only Capsule 4 was disassembled to separate the outer ring, inner ring, and compacts for measurements. The remaining fuel bodies have been retained intact, as they are to be subjected to post-irradiation heating tests to examine fission product release at elevated temperatures in varying environments.

\subsubsection{Precision Gamma Scanning of Rings}

Compacts and inner and outer rings were gamma scanned on the Precision Gamma Scanner (PGS) located at HFEF at INL to determine their total inventories of gamma-emitting fission products (Harp et al. 2016a). All standard capsule rings and compacts were scanned, and the Capsule 4 fuel body was disassembled so that its contents could be scanned. Inner rings, outer rings, and compacts from the other fuel bodies were not scanned. Ring total inventory scans were performed by scanning axially down one half of the ring and then down the other half in a second scan.

In a technique called gamma emission computed tomography (GECT), certain rings (having sufficiently high activity) were rotated and gamma scans were acquired at up to 16 different angles at a single axial level (typically top or middle) of the ring. These scans were then mathematically reconstructed to produce 2-dimensional maps of fission product intensities for selected rings (Harp et al. 2016a). Rings were selected for GECT based on the results of their total inventory scans. Rings with no measureable Ag-110m inventory (i.e., the inner and outer rings from Capsules 1 and 12) were not selected for GECT. The outer rings from Capsules 4 and 5 had very little silver (compared to the other rings) and generally little cesium; thus tomographic scans of the outer rings from these capsules were not acquired. Table 3 summarizes the PGS scans that were completed on rings from each capsule.

Table 3. Summary of AGR-3/4 ring PGS scans.

\begin{tabular}{|c|c|c|c|c|c|c|}
\hline Capsule No. & \multicolumn{3}{|c|}{ Inner Ring } & \multicolumn{3}{c|}{ Outer Ring } \\
\hline & $\begin{array}{c}\text { Axial } \\
\text { Inventory } \\
\text { Scan }\end{array}$ & $\begin{array}{c}\text { GECT } \\
\text { Scans }\end{array}$ & $\begin{array}{c}\text { Location of } \\
\text { GECT Scan }\end{array}$ & $\begin{array}{c}\text { Axial } \\
\text { Inventory } \\
\text { Scan }\end{array}$ & $\begin{array}{c}\text { GECT } \\
\text { Scans }\end{array}$ & $\begin{array}{c}\text { Location of } \\
\text { GECT Scan }\end{array}$ \\
\hline 1 & $\mathrm{Y}$ & $\mathrm{N}$ & $\mathrm{N} / \mathrm{A}$ & $\mathrm{Y}$ & $\mathrm{N}$ & $\mathrm{N} / \mathrm{A}$ \\
\hline $2^{\mathrm{a}}$ & $\mathrm{a}$ & $\mathrm{a}$ & $\mathrm{a}$ & $\mathrm{a}$ & $\mathrm{a}$ & $\mathrm{a}$ \\
\hline 3 & $\mathrm{Y}$ & $\mathrm{Y}$ & $\mathrm{M}, \mathrm{T}$ & $\mathrm{Y}$ & $\mathrm{Y}$ & $\mathrm{M}$ \\
\hline $4^{\mathrm{b}}$ & $\mathrm{Y}$ & $\mathrm{Y}$ & $\mathrm{M}$ & $\mathrm{Y}$ & $\mathrm{N}$ & $\mathrm{N} / \mathrm{A}$ \\
\hline 5 & $\mathrm{Y}$ & $\mathrm{Y}$ & $\mathrm{M}$ & $\mathrm{Y}$ & $\mathrm{N}$ & N/A \\
\hline $6^{\mathrm{a}}$ & $\mathrm{a}$ & $\mathrm{a}$ & $\mathrm{a}$ & $\mathrm{a}$ & $\mathrm{a}$ & $\mathrm{a}$ \\
\hline 7 & $\mathrm{Y}$ & $\mathrm{Y}$ & $\mathrm{M}$ & $\mathrm{Y}$ & $\mathrm{Y}$ & $\mathrm{M}$ \\
\hline 8 & $\mathrm{Y}$ & $\mathrm{Y}$ & $\mathrm{M}, \mathrm{T}$ & $\mathrm{Y}$ & $\mathrm{Y}$ & $\mathrm{M}$ \\
\hline
\end{tabular}


Table 3. (continued).

\begin{tabular}{|c|c|c|c|c|c|c|c|}
\hline \multicolumn{2}{|c|}{ Capsule No. } & \multicolumn{3}{|c|}{ Inner Ring } & \multicolumn{3}{|c|}{ Outer Ring } \\
\hline & & $\begin{array}{c}\text { Axial } \\
\text { Inventory } \\
\text { Scan }\end{array}$ & $\begin{array}{l}\text { GECT } \\
\text { Scans }\end{array}$ & $\begin{array}{l}\text { Location of } \\
\text { GECT Scan }\end{array}$ & $\begin{array}{c}\text { Axial } \\
\text { Inventory } \\
\text { Scan }\end{array}$ & $\begin{array}{l}\text { GECT } \\
\text { Scans }\end{array}$ & $\begin{array}{l}\text { Location of } \\
\text { GECT Scan }\end{array}$ \\
\hline & $9^{\mathrm{a}}$ & $\mathrm{a}$ & a & a & a & a & a \\
\hline & 10 & $\mathrm{Y}$ & $\mathrm{Y}$ & $\mathrm{M}, \mathrm{T}$ & $\mathrm{Y}$ & $\mathrm{Y}$ & $\mathrm{M}$ \\
\hline & $11^{\mathrm{a}}$ & $\mathrm{a}$ & $\mathrm{a}$ & a & ${ }^{\mathrm{a}}$ & $\mathrm{a}$ & $\mathrm{a}$ \\
\hline & 12 & $\mathrm{Y}$ & $\mathrm{N}$ & N/A & $\mathrm{Y}$ & $\mathrm{N}$ & N/A \\
\hline $\begin{array}{l}\mathrm{M} \\
\mathrm{N} \\
\mathrm{N} / \mathrm{A} \\
\mathrm{T} \\
\mathrm{Y} \\
\text { a. } \\
\text { b. }\end{array}$ & $\begin{array}{l}\text { middle } \\
\text { no } \\
\text { not applic: } \\
\text { top } \\
\text { yes } \\
\text { fuel body } \\
\text { fuel body }\end{array}$ & $\begin{array}{l}\text { disassembled } \\
\text { assembled for }\end{array}$ & inning & & & & \\
\hline
\end{tabular}

\subsubsection{Other Gamma Counting}

2.1.3.1 Foils, Felts, and Spacers. Foils and felts were made of Graftech Grafoil and grade WDF graphite, respectively. From each capsule, the inner foils were packaged and counted together, and the outer foils were packaged and counted together on the Hot Cell 4 gamma spectrometer at the AL. The measured activities from the inner and outer foils were added together to give the foil inventory. The Hot Cell 4 spectrometer consists of a high purity germanium detector that looks through a $0.762 \mathrm{~mm}(0.03 \mathrm{in})$ thick aluminum window and a $25.4 \mathrm{~mm}$ (1 in) diameter by $203.2 \mathrm{~mm}$ ( $8 \mathrm{in})$ long lead collimator mounted in the cell concrete wall as shown in Figure 6. The felts from each capsule were packaged along with the screws recovered from the sink ring lid from each capsule. Unless otherwise noted, the felts and screws were counted together at the HFEF Out-of-cell Gamma Station (HOGS). The Capsule 7 and 10 felts had too much activity to count on the HOGS. Those felts were separated from the screws and transferred to AL for gamma counting, and the measured activities of the screws and felts were added.

Spacers went through several rounds of gamma counting to arrive at a consistent geometry. Spacers were ultimately counted individually (rather than in pairs) by placing each spacer flat against the bottom of a plastic snap-cap container and fixing the spacer in place by filling the empty volume of the container with foam. One side of the spacers was flat and the other side had ridges. During irradiation, the ridge-side of the spacer faced the compacts. Thus, the ridge-side of the spacer was faced toward the gamma detector. A new standard was created to calibrate the geometry. Hot cell gamma background was subtracted from the measured activities. The measured activities from each spacer from the same capsule were added together. 


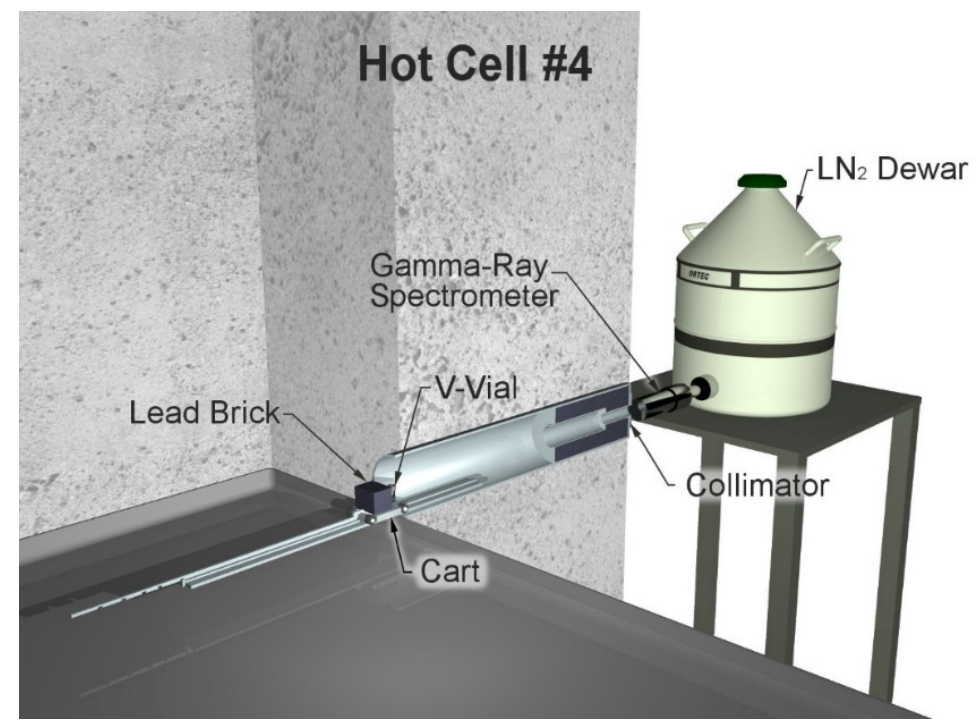

Figure 6. Gamma spectrometry system in Hot Cell 4 at the AL. (The can roller used for sink ring counting is not pictured).

2.1.3.2 Sink Rings. Sink rings were transferred from HFEF to Hot Cells at the AL. The size of the sink rings prohibited the use of the Pneumatic Transfer System, which can accept items with diameters up to $41.275 \mathrm{~mm}$ (1.625 in). For the first transfer, the Capsule 1 sink ring (Sink 1) was mechanically broken into smaller pieces that fit into the snap-cap containers used in the Pneumatic Transfer System rabbits. The potential for loss of material during this breakup process led to the manual transfer of intact sink rings using a small, shielded container known as the Dry Active Waste (DAW) cask.

To reduce the potential of contamination and ease handling, rings were placed into closed-cell foam-cushioned, half-pint ( $236 \mathrm{~mL}$ ) paint cans during experiment disassembly at HFEF (prior to shipment to AL). Once at AL, it was found that the rings contained too much activity and were effectively too large to be counted with the sample positioning cart in close proximity to the gamma detector in the AL Hot Cell 4. A fixture was constructed that allowed consistent measurement of the rings by the Hot Cell 4 spectrometer.

The spectrometer was configured to count non-uniformly distributed activity by continuously rotating a large sample can along its horizontal axis during the counting step. The field of view for the gamma collimator is approximately one-quarter of the can when looked at end-on. The cans normally counted in the fixture are $228.6 \mathrm{~mm}$ ( 9 in) in diameter by $279.4 \mathrm{~mm}(11 \mathrm{in})$ tall. To count the $63.5 \mathrm{~mm}(2.5 \mathrm{in})$ diameter sink rings, a $228.6 \mathrm{~mm}$ (9 in) diameter can was assembled with used closed-cell foam spacers to center the sink ring can with the can lid and sink ring lid removed and the open end oriented toward the detector. When placed on the can roller, one quarter of the ring was centered in the gamma collimator field of view. With continuous rolling throughout the duration of the count, the entirety of the ring was counted. The roller arrangement is shown in Figure 7. A calibration standard was constructed using a 3-D printed component with the same dimensions and features as a sink ring. This standard was filled with epoxy and a europium-152 mixture that provided a uniform distribution of source material in the center cavity of the standard.

The sink ring lids were counted separately since positioning the sink ring lid on the ring while counting was problematic, and most lids were partially damaged during disassembly. Most lids were contained in small polyethylene bags. To count, they were suspended in the line of the collimator field of view for the desired time. The first few lids (from Capsules 1, 3, and 7) were not rotated in front of the collimator. However, beginning with Sink Rink 5 and continuing for all other sinks, the lid was placed by itself in the foam-cushioned half-pint paint cans inside the $7.57 \mathrm{~L}$ ( 2 gallon) can and rotated on the can 
roller in front of the collimator for counting. The measured activities on the lid were added to those measured on the ring itself.

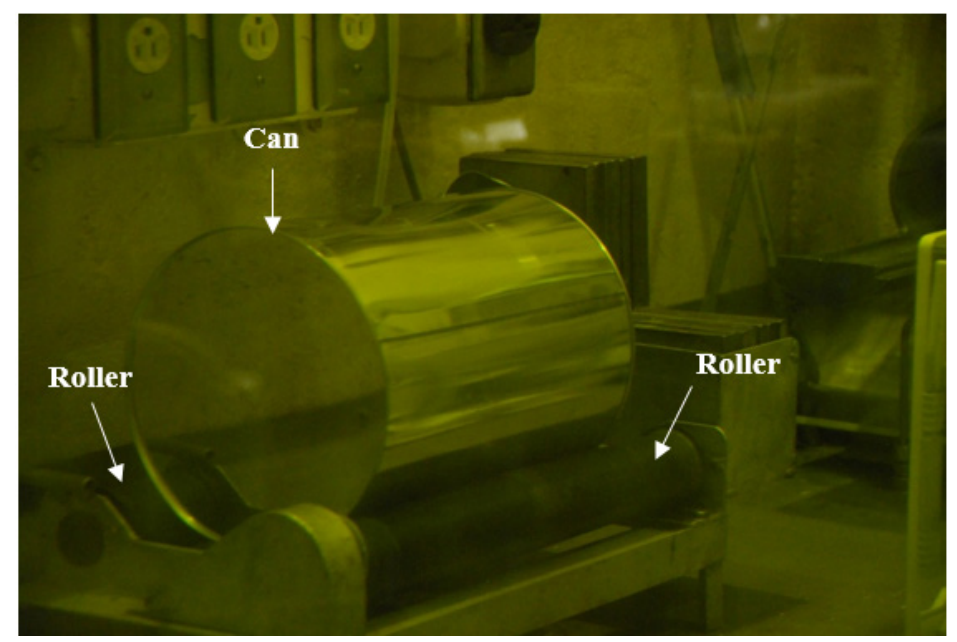

Figure 7. 7.57 L (2 gallon) can on roller in line with Hot Cell 4 spectrometer.

\subsection{Destructive Analysis Methods}

\subsubsection{Through Tubes}

Each capsule had three stainless steel through tubes that ran through holes in the sink rings to carry capsule instrumentation. The through tubes were attached to the capsule head and bottom. During test train disassembly, the through tubes were destructively separated from the head and bottom (Stempien et al. 2016). The through tubes were transferred to AL and leached once in $8 \mathrm{M}$ nitric acid for 20 minutes at boiling. After cooling, the tubes were rinsed with deionized water. The rinse was combined with the leachate, and the leachate counted for gamma-emitting fission products. Solutions were gamma counted at either of two high-purity germanium detectors outside of the hot cell. A separation and gas proportional counting was performed to measure beta-emitting Sr-90. Inductively-coupled plasma-mass spectrometry (ICP-MS) was also performed on the leachate. Leaching was necessary to extract the trace quantity of fission products from the highly activated steel to facilitate detection.

\subsubsection{Inner and Outer Rings}

Destructive ring sampling has been performed on the inner and outer rings from Capsules 3, 5, 7, and 8 . Each ring was filled with epoxy to stabilize the ring and mounted on a rotating chuck. An end-mill (with a $10 \mathrm{~mm}$ wide bit) removed material from the ring in 10 to 15 steps of $0.5 \mathrm{~mm}$ depth (depending on the thickness of the ring), and a cyclone separator collected the fines from each radial segment of the ring. The mill and cyclone separator are shown in Figure 8. Most of the rings to undergo sampling were sampled at one of their axial ends (either top or bottom) and in the axial center. All samples were sent to the Pacific Northwest National Laboratory for gamma counting and burn-leach analysis. See (Trang-le 2018 and Pool 2018) for details on the burn-leach, gamma counting, and Sr-90 analysis processes. These data have been used to construct radial concentration profiles of fission products at specific axial locations within the rings. The data are also useful for comparing to measurements made with the PGS and to results from simulations. Since the inner and outer rings were $5.08 \mathrm{~cm}$ tall (2 in) and were sampled in two $10-\mathrm{mm}$-wide swaths at the axial top and axial center, roughly $60 \%$ of the volume of the sampled rings remains. (These remnants can be used for other PIE such as heating tests.) Thus, the Sr-90 mass balance of the rings is only a partial balance. Estimates of the complete Sr-90 balance in the rings could be made by extrapolating existing sampling data to the rest of the ring. Once these extrapolations have 
been made, estimated Sr-90 balances for these rings will be included with the gamma-emitting fission product balances in these rings.

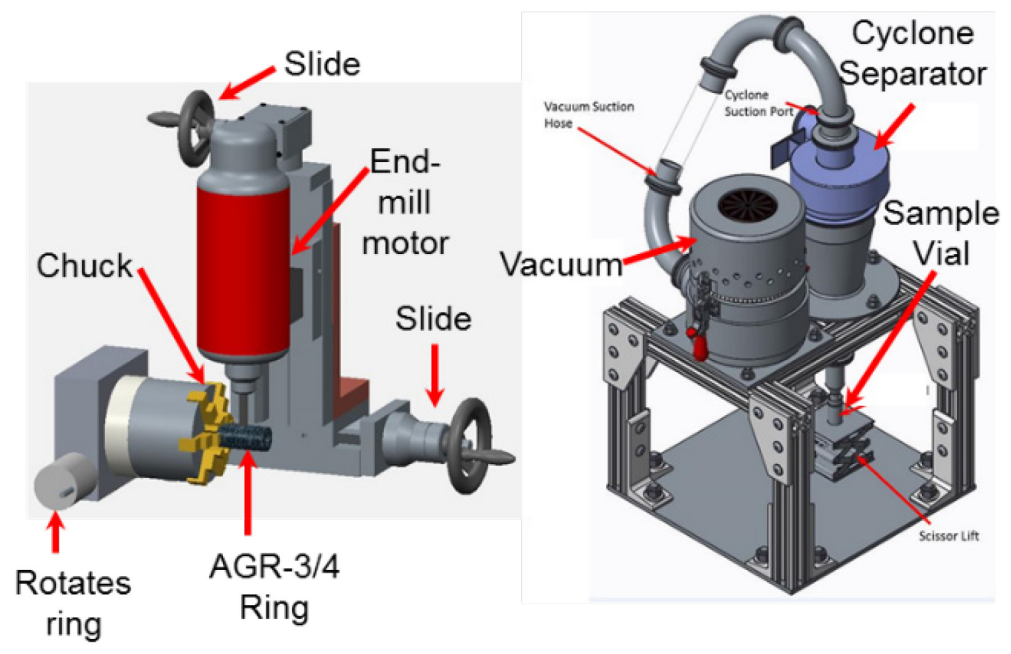

Figure 8. Equipment used for physical ring sampling. End mill (left) and cyclone separator (right).

\subsubsection{Sink Rings}

After gamma counting, sink rings were oxidized in air and leached. Sink rings were placed in fused silica beakers with vented lids and put into the Hot Cell 5 Vulcan 3-550 air furnace. This unit operates up to $1000^{\circ} \mathrm{C}$ and has venting to allow air flow through the heated volume. A small electric fan was used to promote air flow through a duct at the back of the furnace into the heated zone. A $6.35 \mathrm{~mm}(0.25 \mathrm{in})$ airline connected to the building compressed air supply was also added. For purposes of sink ring oxidation, the unit was generally operated between 750 and $800^{\circ} \mathrm{C}$. Sink oxidation times ranged from 155 to 400 hours to achieve completion. This variation is speculated to be due to the inconsistent and limited air flow from the furnace heated volume into the beaker holding the sink ring.

Except for the Capsule 8 and 10 sink rings, the sink ring body was oxidized separately from the lid. Bulk oxidation of the sink rings was done, then the lid was added to the same beaker for oxidation of the lid. The reasoning for this serial approach was that if the lid created a closed volume when placed on the sink body, there would be less access for oxygen, and the oxidation step would take longer.

A sample of broken IG-110 grade graphite was placed in the furnace to provide a material blank for comparison of the first few sink ring oxidations. For Sink Ring 5, an unirradiated sink ring body was fabricated of IG-110 and oxidized at the same time as the irradiated ring. Blank unirradiated sink ring bodies made of PCEA grade graphite were oxidized with Sink Rings 4 and $11^{\mathrm{b}}$. The nominal rate of oxidation was 1 gram of carbon per hour. No definitive distinction could be made between unirradiated and irradiated rates of oxidation. Little to no activity was measured on the material blanks from hot cell contamination or cross-contamination. Only one irradiated sink ring was oxidized at a time in the furnace.

With the exception of Sink Rings 4 and $5^{\mathrm{c}}$, most burns went to completion, leaving an ash residue that covered the bottom of the beakers. Before and after pictures of Sink Ring 7 are shown in Figure 9 as an

b Since the ring was damaged during disassembly and to prevent further damage from attempts at removal, Sink Ring 11 was oxidized with its fluence monitors (flux wires) still in place. The metal pieces were removed from the leach residue and gamma counted separately.

c Particular anomalies noted during this process included the presence of insoluble residue from Sink Ring 4 and 5 oxidation that resembled oatmeal flakes. Using scanning electron microscopy-energy-dispersive $\mathrm{x}$-ray spectroscopy, the significant constituents of the flakes were antimony and tin. It may be that contact with zircaloy spacers led to this deposition. 
example of "complete" oxidation. To provide a solution for ICP-MS, solution gamma counting, and Sr-90 analysis, the residual ash from the irradiated sink ring oxidation was leached by adding $8 \mathrm{M}$ nitric acid to the fused silica oxidation beaker. This concentration was used for all sink rings except Sink Ring 6, which was leached in $16 \mathrm{M}$ nitric acid and showed no significant difference in dissolution of residual solids compared to the leaches with $8 \mathrm{M}$ nitric acid. The beaker was placed on a hot plate and the acid and ash were heated to near boiling for approximately 1 hour per leach cycle. A matrix or equipment blank was made by adding the same concentration of high purity acid to a tall form beaker that was handled in the same hot cell as the ash leach beaker.

Different combinations of leaching and leachate analyses were used. Except for the Capsule 1 and 5 sink rings, the ash remaining after oxidation was leached twice. The Capsule 1 ash was leached once, and the solution analyzed in triplicate. The triplicate results were averaged, and the measurement errors were propagated to the average. Residual solids remained after the first oxidation of the Capsule 5 sink ring. These remnants were leached twice, a second burn was performed, and the remnants were leached another four times. Each solution was analyzed a single time with no duplicates. The results from the 6 leaches were summed to give the total activity from the leach of the Capsule 5 sink ring. Capsules 2, 4, 6, and 9-12 sink rings were leached twice, and each of the two leach solutions was analyzed a single time. The fission product activities and measurement errors from the two leaches were combined to give the total fission product inventory (and associated error) from the two leaches. The Capsule 3 and 7 sink rings were oxidized and leached twice. The two leach solutions were combined into a composite solution for each capsule. The resulting composite solutions were analyzed in triplicate. The triplicate results within Capsule 3 and 7 were averaged, and the measurement error from each of the triplicate measurements was propagated to the average. Finally, the Capsule 8 sink ring body and lid were leached twice separately, and the leachates were analyzed a single time (no duplicates were performed). The results from the two leaches of the body and lid were summed to give the totals for the Capsule 8 sink ring leach.
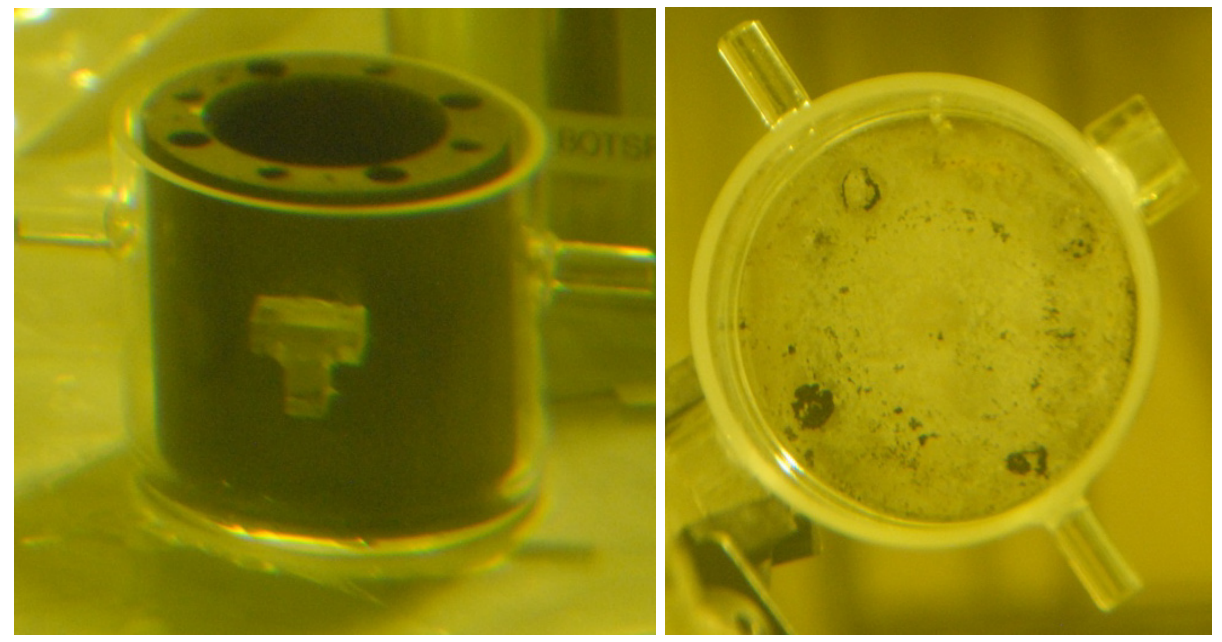

Figure 9. Sink Ring 7 prior to oxidation (left). Ash remaining after Sink Ring 7 oxidation (right).

\subsubsection{Foils, Felts, and Spacers}

Foils and felts were made of Graftech Grafoil and grade WDF graphite, respectively. After gamma counting (described in Section 2.1.3.1), all the foils from a given capsule were placed in the same fused silica container, oxidized in a muffle furnace at $750^{\circ} \mathrm{C}$ in Hot Cell 5 at the AL, and leached twice in $8 \mathrm{M}$ nitric acid at a gentle boil. Three aliquots from each of the two leachate solutions were analyzed. The leachate was gamma counted, a Sr-90 separation was performed, gas proportional counting for Sr-90 was carried out, and ICP-MS was done. The triplicate results from the first leach were averaged, and the error from each individual measurement was propagated to the average. The same was done for the second leach. To give the total activity leached from the foils, the leach 1 and leach 2 averages were added 
together, and the measurement errors were propagated. The felts still require burn-leach analysis to measure beta-emitting Sr-90.

The spacers were zircaloy-4 metal in Capsules 1 through 6, but in Capsules 7 through 12, the spacers were zirconia ceramic. After gamma counting the spacers (described in Section 2.1.3.1), spacers from the same capsule were combined, leached, and the leachate went through gamma counting, a Sr-90 separation, gas proportional counting for Sr-90, and ICP-MS. Each group of spacers was leached twice, and the two solutions (leach 1 and leach 2) were combined into a "composite" for analysis. The composite leach solutions from Capsules 3, 6, 7, and 8 were analyzed in triplicate. The triplicate results within each capsule were averaged, and the measurement error from each of the three measurements was propagated to the average. Duplicate analyses were not performed on the solutions from the other capsules.

\subsubsection{Capsule Shells}

Sink rings were intentionally cold (relative to other capsule components) to act as a sink to stop radial transport of fission products beyond the sinks during the experiment. Based on this capsule design, it was assumed that significant amounts of fission products would not reach the stainless steel capsule shells. Therefore, the shells were not leached.

\section{RESULTS}

Each of the 12 capsules had a different combination of irradiation temperature, materials, and type (fuel body versus standard). Therefore, results for each capsule are first presented individually. Where appropriate, comparisons between capsules are made in Section 4. Detected radioisotope activities were decay-corrected to April 13, 2014 at 5:00 AM MT. This date and time corresponds to the end of the AGR-3/4 irradiation plus 1 day. Decay corrections were made using the following equation:

$A=A_{o} e^{-\lambda t}$

where $A$ is the activity at time $t, A_{o}$ is the activity at $t=0$, and $\lambda$ is the decay constant. The decay constant is defined as $\lambda=\ln (2) / t_{1 / 2}$, where $t_{1 / 2}$ is the half-life. Half-lives for each isotope were taken from the ENDF/B-VII.1 library downloaded on July 9, 2013 (Chadwick et al. 2011). In instances where no activity was detected for a given isotope, minimum detectable activities (MDAs) were determined. These MDAs were also decay-corrected and should be considered an upper bound on the activity of a given component. To calculate the capsule fractions, decay-corrected activities for each isotope were divided by the total activity of that isotope predicted from physics calculations (Sterbentz 2015) to have been produced during irradiation. With 7568 particles in each capsule, a capsule fraction of $1.32 \mathrm{E}-4$ corresponds to the inventory of a single particle.

In the following sections (Sections 3.1 through 3.12), results are presented for each individual capsule. For each capsule, one table is given for the capsule hardware (foils, felts, spacers, and through tubes), and one table is given for the inner/outer/sink rings. In the table for the capsule hardware, the column labeled "Total (measured only)" is the sum of the measured (detected) activities from each component. This column represents a "lower bound" on the inventory of a given isotope. When a given isotope was not detected, an MDA was determined. The column "Total (measured + MDA)" gives the sum of all measured (detected) values and any values derived from MDAs. This column represents an "upper bound" on the possible inventory of a fission product. Cells are shaded for cases where an MDA, or a sum of MDAs, accounts for greater than $50 \%$ of the total from the sum of the measured values plus MDAs. With these two totals representing upper and lower bounds, the true total value of the inventory of an isotope lies somewhere in-between. For example, in Table 4, Ag-110m was not detected on any of the capsule components; therefore, the sum of the measured values (lower bound) is zero, but the capsule fraction derived from the sum of the Ag-110m MDAs is 1.76E-2 (upper bound). In this example of Capsule 1, there is considerable uncertainty in the true value of Ag-110m that may exist on the capsule hardware (0 to $1.76 \mathrm{E}-2)$. 
In the table summarizing the ring activities, the column labeled "Hardware (measured + MDA)" is the same as the column "Total (measured + MDA)" from the table of capsule hardware activities (e.g., Table 4). The two columns labeled "Grand Total" represent the upper and lower bounds of the fission product inventory measured outside of the fuel compacts in a given capsule. The "Grand Total (measured only)" column does not contain any MDAs. It is the sum of the right-most column from the table of capsule hardware plus all un-shaded cells from the inner, outer, and sink rings. If no activity was measured in any of the capsule components or rings, there is a zero in this column. The two right-most columns in the table for the rings (e.g., Table 5) are the propagated relative error of the sums of all the measured values (values for which there was detectable activity). Column "error (\% minus)" is the lower uncertainty bound, and column "error (\% plus)" is the upper uncertainty bound for the column "Grand Total (measured only)". Note that in some cases, the uncertainty is asymmetrical (i.e., the upper bound uncertainty is higher than the lower bound uncertainty). This is due to the reported uncertainty from the PGS counts of the inner and outer rings (Harp et al. 2016a). Where no activity was detected in any component, a measurement uncertainty cannot be determined, and the cell is left blank.

Sections 3.1 through 3.12 report on selected isotopes (Ag-110m, Ce-144, Cs-134, Cs-137, Eu-154, and Sr-90). The summary tables in Section 3.13 include all of these isotopes plus Eu-155 and Ru-106. Greater emphasis is placed on Eu-154 versus Eu-155. Eu-154 has higher-energy gamma rays that are often more readily detectible (and typically with lower error) than Eu-155 in AGR PIE. Although, that has not always been the case for all components of AGR-3/4 PIE. The measured Cs-137 and Cs-134 are generally in good agreement, but due to trace contamination of the longer-lived Cs-137 in the hot cell, Cs-137 readings are usually biased higher than Cs-134. Ruthenium does not readily transport beyond the TRISO particles, thus little Ru-106 was measured, and it is only tabulated in the summary tables in Section 3.13. Sb-125 was detected; however, it is not reported here because the spacers in Capsules 1 through 6 were made of zircaloy-4, and Sn is an alloying element in zircaloy-4. The Sn-124 isotope (5.8\% of all natural Sn), in particular, transmuted to Sb-125 and caused spuriously high Sb-125 readings in those capsules. 


\subsection{Capsule 1}

Capsule 1 was a standard-type capsule and was one of the coldest capsules in the irradiation. Table 4 shows the activities, capsule fractions, and particle equivalents for selected isotopes measured on the capsule hardware. Table 5 represents the entire mass balance for Capsule 1 (inner ring, outer ring, sink ring, foils, felts, spacers, and through tubes).

Table 4. Summary of major isotopes in Capsule 1 hardware. Shaded cells are based entirely on MDAs or cases where MDAs account for $>50 \%$ of a sum of MDAs and measured values.

\begin{tabular}{|c|c|c|c|c|c|c|}
\hline Capsule 1 & Foils & Felts $^{\mathbf{a}}$ & Spacers & $\begin{array}{c}\text { Through } \\
\text { Tubes }\end{array}$ & $\begin{array}{c}\text { Total } \\
\text { (measured }+ \\
\text { MDA) }\end{array}$ & $\begin{array}{c}\text { Total } \\
\text { (measured } \\
\text { only) }\end{array}$ \\
\hline \multicolumn{7}{|c|}{ Decay-Corrected Activity (Bq) } \\
\hline $\mathrm{Ag}-110 \mathrm{~m}$ & $2.15 \mathrm{E}+05$ & $1.89 \mathrm{E}+03$ & $2.77 \mathrm{E}+05$ & $9.68 \mathrm{E}+04$ & $5.90 \mathrm{E}+05$ & 0 \\
\hline Cs-134 & $8.25 \mathrm{E}+05$ & $1.60 \mathrm{E}+04$ & $2.41 \mathrm{E}+04$ & $1.79 \mathrm{E}+04$ & $8.83 \mathrm{E}+05$ & $8.59 \mathrm{E}+05$ \\
\hline Cs-137 & $4.79 \mathrm{E}+06$ & $2.84 \mathrm{E}+04$ & $2.20 \mathrm{E}+05$ & $6.85 \mathrm{E}+04$ & $5.11 \mathrm{E}+06$ & $5.11 \mathrm{E}+06$ \\
\hline $\mathrm{Ce}-144$ & $1.48 \mathrm{E}+06$ & $1.55 \mathrm{E}+04$ & $2.32 \mathrm{E}+06$ & $1.95 \mathrm{E}+05$ & $4.02 \mathrm{E}+06$ & 0 \\
\hline Eu-154 & $2.11 \mathrm{E}+04$ & $1.17 \mathrm{E}+02$ & $1.33 \mathrm{E}+04$ & $9.58 \mathrm{E}+03$ & $4.41 \mathrm{E}+04$ & $3.45 \mathrm{E}+04$ \\
\hline $\mathrm{Sr}-90$ & $9.87 \mathrm{E}+03$ & $\mathrm{~b}$ & $1.89 \mathrm{E}+03$ & $2.06 \mathrm{E}+04$ & $3.23 \mathrm{E}+04$ & $3.23 \mathrm{E}+04$ \\
\hline \multicolumn{7}{|c|}{ Capsule Fraction } \\
\hline Ag-110m & $6.37 \mathrm{E}-03$ & $5.60 \mathrm{E}-05$ & $8.21 \mathrm{E}-03$ & $2.87 \mathrm{E}-03$ & $1.75 \mathrm{E}-02$ & 0 \\
\hline Cs-134 & $1.46 \mathrm{E}-04$ & $2.85 \mathrm{E}-06$ & 4.27E-06 & $3.18 \mathrm{E}-06$ & $1.57 \mathrm{E}-04$ & $1.52 \mathrm{E}-04$ \\
\hline Cs-137 & $3.91 \mathrm{E}-04$ & $2.32 \mathrm{E}-06$ & $1.80 \mathrm{E}-05$ & $5.58 \mathrm{E}-06$ & 4.17E-04 & 4.17E-04 \\
\hline Ce-144 & $7.41 \mathrm{E}-06$ & $7.78 \mathrm{E}-08$ & $1.16 \mathrm{E}-05$ & $9.75 \mathrm{E}-07$ & $2.01 \mathrm{E}-05$ & 0 \\
\hline Eu-154 & $1.11 \mathrm{E}-04$ & $6.15 \mathrm{E}-07$ & $6.95 \mathrm{E}-05$ & $5.02 \mathrm{E}-05$ & $2.31 \mathrm{E}-04$ & $1.81 \mathrm{E}-04$ \\
\hline Sr-90 & $8.68 \mathrm{E}-07$ & $\mathrm{~b}$ & $1.66 \mathrm{E}-07$ & $1.81 \mathrm{E}-06$ & $2.84 \mathrm{E}-06$ & $2.84 \mathrm{E}-06$ \\
\hline \multicolumn{7}{|c|}{ Particle Equivalents } \\
\hline Ag-110m & $4.82 \mathrm{E}+01$ & 4.24E-01 & $6.21 \mathrm{E}+01$ & $2.17 \mathrm{E}+01$ & $1.32 \mathrm{E}+02$ & 0 \\
\hline Cs-134 & $1.11 \mathrm{E}+00$ & $2.15 \mathrm{E}-02$ & $3.23 \mathrm{E}-02$ & $2.40 \mathrm{E}-02$ & $1.19 \mathrm{E}+00$ & $1.15 \mathrm{E}+00$ \\
\hline Cs-137 & $2.96 \mathrm{E}+00$ & $1.75 \mathrm{E}-02$ & $1.36 \mathrm{E}-01$ & 4.23E-02 & $3.16 \mathrm{E}+00$ & $3.16 \mathrm{E}+00$ \\
\hline Ce-144 & $5.61 \mathrm{E}-02$ & $5.89 \mathrm{E}-04$ & $8.81 \mathrm{E}-02$ & $7.38 \mathrm{E}-03$ & $1.52 \mathrm{E}-01$ & 0 \\
\hline Eu-154 & 8.37E-01 & $4.66 \mathrm{E}-03$ & $5.26 \mathrm{E}-01$ & $3.80 \mathrm{E}-01$ & $1.75 \mathrm{E}+00$ & $1.37 \mathrm{E}+00$ \\
\hline Sr-90 & $6.57 \mathrm{E}-03$ & $\mathrm{~b}$ & $1.26 \mathrm{E}-03$ & $1.37 \mathrm{E}-02$ & $2.15 \mathrm{E}-02$ & $2.15 \mathrm{E}-02$ \\
\hline
\end{tabular}


Table 5. Inventories in capsule rings, total hardware inventories (sum from Table 4), and total inventory measured outside of the fuel (Grand Totals). Errors are given based on propagation of uncertainty across the sum of all measured values. Shaded cells are based entirely on MDAs or cases where MDAs account for $>50 \%$ of a sum of MDAs and measured values.

\begin{tabular}{|c|c|c|c|c|c|c|c|c|}
\hline Capsule 1 & $\begin{array}{l}\text { Inner } \\
\text { Ring }\end{array}$ & $\begin{array}{c}\text { Outer } \\
\text { Ring }\end{array}$ & $\begin{array}{l}\text { Sink } \\
\text { Ring }\end{array}$ & $\begin{array}{c}\text { Hardware } \\
\text { (measured } \\
+ \text { MDA) } \\
\end{array}$ & $\begin{array}{c}\text { Grand } \\
\text { Total } \\
\text { (measured } \\
+ \text { MDA) }\end{array}$ & $\begin{array}{c}\text { Grand } \\
\text { Total } \\
\text { (measured } \\
\text { only) }\end{array}$ & $\begin{array}{c}\text { Error } \\
(\% \text { minus }) \\
\end{array}$ & $\begin{array}{c}\text { Error } \\
\text { (\% plus) }\end{array}$ \\
\hline $\begin{array}{c}\text { Ring } \\
\text { Material }\end{array}$ & Matrix & PCEA & PCEA & N/A & N/A & N/A & N/A & N/A \\
\hline $\begin{array}{c}\text { TAVA } \\
\text { Temp }\left({ }^{\circ} \mathrm{C}\right) \\
\end{array}$ & 853 & 765 & 517 & N/A & N/A & N/A & N/A & N/A \\
\hline \multicolumn{9}{|c|}{ Decay-Corrected Activity (Bq) } \\
\hline $\mathrm{Ag}-110 \mathrm{~m}$ & $1.73 \mathrm{E}+06$ & $1.74 \mathrm{E}+06$ & $9.93 \mathrm{E}+04$ & $5.90 \mathrm{E}+05$ & $4.15 \mathrm{E}+06$ & $9.93 \mathrm{E}+04$ & $7.4 \%$ & $7.4 \%$ \\
\hline Cs-134 & $2.78 \mathrm{E}+06$ & $1.04 \mathrm{E}+05$ & $8.03 \mathrm{E}+04$ & $8.83 \mathrm{E}+05$ & $3.84 \mathrm{E}+06$ & $3.82 \mathrm{E}+06$ & $3.9 \%$ & $20.1 \%$ \\
\hline Cs-137 & $8.96 \mathrm{E}+06$ & $1.25 \mathrm{E}+06$ & $1.30 \mathrm{E}+05$ & $5.11 \mathrm{E}+06$ & $1.55 \mathrm{E}+07$ & $1.55 \mathrm{E}+07$ & $2.0 \%$ & $2.6 \%$ \\
\hline $\mathrm{Ce}-144$ & $\mathrm{~N} / \mathrm{D}$ & $\mathrm{N} / \mathrm{D}$ & $6.76 \mathrm{E}+04$ & $4.02 \mathrm{E}+06$ & $4.08 \mathrm{E}+06$ & 0 & - & - \\
\hline Eu-154 & $1.70 \mathrm{E}+05$ & $9.25 \mathrm{E}+05$ & $3.92 \mathrm{E}+03$ & $4.41 \mathrm{E}+04$ & $1.14 \mathrm{E}+06$ & $2.05 \mathrm{E}+05$ & $23.7 \%$ & $469.8 \%$ \\
\hline Sr-90 & a & a & $2.05 \mathrm{E}+04$ & $3.23 \mathrm{E}+04$ & $5.28 \mathrm{E}+04$ & $5.28 \mathrm{E}+04$ & $3.2 \%$ & $3.2 \%$ \\
\hline \multicolumn{9}{|c|}{ Capsule Fraction } \\
\hline $\mathrm{Ag}-110 \mathrm{~m}$ & $5.13 \mathrm{E}-02$ & $5.15 \mathrm{E}-02$ & $2.94 \mathrm{E}-03$ & $1.75 \mathrm{E}-02$ & $1.23 \mathrm{E}-01$ & $2.94 \mathrm{E}-03$ & $7.4 \%$ & $7.4 \%$ \\
\hline Cs-134 & $4.90 \mathrm{E}-04$ & $1.86 \mathrm{E}-05$ & $1.42 \mathrm{E}-05$ & $1.57 \mathrm{E}-04$ & $6.80 \mathrm{E}-04$ & $6.75 \mathrm{E}-04$ & $3.9 \%$ & $20.1 \%$ \\
\hline Cs-137 & $7.30 \mathrm{E}-04$ & $1.02 \mathrm{E}-04$ & $1.06 \mathrm{E}-05$ & 4.17E-04 & $1.26 \mathrm{E}-03$ & $1.26 \mathrm{E}-03$ & $2.0 \%$ & $2.6 \%$ \\
\hline $\mathrm{Ce}-144$ & $\mathrm{~N} / \mathrm{D}$ & $\mathrm{N} / \mathrm{D}$ & $3.38 \mathrm{E}-07$ & $2.01 \mathrm{E}-05$ & $2.04 \mathrm{E}-05$ & 0 & - & - \\
\hline Eu-154 & $8.90 \mathrm{E}-04$ & $4.84 \mathrm{E}-03$ & $2.05 \mathrm{E}-05$ & $2.31 \mathrm{E}-04$ & $5.98 \mathrm{E}-03$ & $1.07 \mathrm{E}-03$ & $23.7 \%$ & $469.8 \%$ \\
\hline Sr-90 & a & a & $1.80 \mathrm{E}-06$ & $2.84 \mathrm{E}-06$ & 4.64E-06 & 4.64E-06 & $3.2 \%$ & $3.2 \%$ \\
\hline \multicolumn{9}{|c|}{ Particle Equivalents } \\
\hline $\mathrm{Ag}-110 \mathrm{~m}$ & $3.88 \mathrm{E}+02$ & $3.90 \mathrm{E}+02$ & $2.23 \mathrm{E}+01$ & $1.32 \mathrm{E}+02$ & $9.33 \mathrm{E}+02$ & $2.23 \mathrm{E}+01$ & $7.4 \%$ & $7.4 \%$ \\
\hline Cs-134 & $3.71 \mathrm{E}+00$ & $1.41 \mathrm{E}-01$ & $1.08 \mathrm{E}-01$ & $1.19 \mathrm{E}+00$ & $5.14 \mathrm{E}+00$ & $5.11 \mathrm{E}+00$ & $3.9 \%$ & $20.1 \%$ \\
\hline Cs-137 & $5.52 \mathrm{E}+00$ & 7.72E-01 & 8.03E-02 & $3.16 \mathrm{E}+00$ & $9.53 \mathrm{E}+00$ & $9.53 \mathrm{E}+00$ & $2.0 \%$ & $2.6 \%$ \\
\hline $\mathrm{Ce}-144$ & N/D & N/D & $2.56 \mathrm{E}-03$ & $1.52 \mathrm{E}-01$ & $1.55 \mathrm{E}-01$ & 0 & - & - \\
\hline Eu-154 & $6.74 \mathrm{E}+00$ & $3.66 \mathrm{E}+01$ & $1.55 \mathrm{E}-01$ & $1.75 \mathrm{E}+00$ & $4.53 \mathrm{E}+01$ & $8.10 \mathrm{E}+00$ & $23.7 \%$ & $469.8 \%$ \\
\hline Sr-90 & a & a & $1.36 \mathrm{E}-02$ & $2.15 \mathrm{E}-02$ & $3.51 \mathrm{E}-02$ & $3.51 \mathrm{E}-02$ & $3.2 \%$ & $3.2 \%$ \\
\hline \multicolumn{9}{|c|}{$\begin{array}{l}\text { N/A not applicable. } \\
\text { N/D not detected on PGS, no MDAs determined. } \\
\text { a. requires destructive analysis to measure. }\end{array}$} \\
\hline
\end{tabular}




\subsection{Capsule 2}

Capsule 2 was a fuel body capsule that was not disassembled; therefore, neither the compacts nor the inner and outer rings could be scanned via PGS. The mass balance outside of the fuel compacts is incomplete without the inner and outer rings. Table 6 shows the activities, capsule fractions, and particle equivalents for selected isotopes measured on the capsule hardware. Table 7 represents the available (incomplete) mass balance for the Capsule 2 fuel body (sink ring, foils, felts, spacers, and through tubes). Except for the Capsule 4 fuel body, all fuel bodies have been retained intact, as they are to be subjected to post-irradiation heating tests (in helium, air, or moisture atmospheres) to examine fission product release at elevated temperatures in varying environments.

Table 6. Summary of major isotopes on Capsule 2 hardware. Shaded cells are based entirely on MDAs or cases where MDAs account for $>50 \%$ of a sum of MDAs and measured values.

\begin{tabular}{|c|c|c|c|c|c|c|}
\hline Capsule 2 & Foils & Felts $^{\mathrm{a}}$ & Spacers & $\begin{array}{c}\text { Through } \\
\text { Tubes }\end{array}$ & $\begin{array}{c}\text { Total } \\
\text { (measured } \\
+ \text { MDA) }\end{array}$ & $\begin{array}{c}\text { Total } \\
\text { (measured } \\
\text { only) }\end{array}$ \\
\hline \multicolumn{7}{|c|}{ Decay-Corrected Activity (Bq) } \\
\hline Ag-110m & $1.10 \mathrm{E}+05$ & $1.74 \mathrm{E}+05$ & $1.24 \mathrm{E}+05$ & $1.18 \mathrm{E}+05$ & $5.26 \mathrm{E}+05$ & 0 \\
\hline Cs-134 & $2.20 \mathrm{E}+06$ & $5.83 \mathrm{E}+05$ & $8.27 \mathrm{E}+04$ & $4.23 \mathrm{E}+05$ & $3.29 \mathrm{E}+06$ & $3.29 \mathrm{E}+06$ \\
\hline Cs-137 & $4.55 \mathrm{E}+06$ & $5.90 \mathrm{E}+05$ & $5.17 \mathrm{E}+04$ & $6.88 \mathrm{E}+05$ & $5.88 \mathrm{E}+06$ & $5.88 \mathrm{E}+06$ \\
\hline $\mathrm{Ce}-144$ & $5.32 \mathrm{E}+05$ & $4.81 \mathrm{E}+05$ & $1.20 \mathrm{E}+06$ & $2.38 \mathrm{E}+05$ & $2.45 \mathrm{E}+06$ & 0 \\
\hline Eu-154 & $7.69 \mathrm{E}+03$ & $4.81 \mathrm{E}+02$ & $9.53 \mathrm{E}+03$ & $2.34 \mathrm{E}+04$ & $4.11 \mathrm{E}+04$ & 0 \\
\hline Sr-90 & $1.56 \mathrm{E}+04$ & $\mathrm{~b}$ & $3.31 \mathrm{E}+03$ & $4.94 \mathrm{E}+04$ & $6.83 \mathrm{E}+04$ & $6.83 \mathrm{E}+04$ \\
\hline \multicolumn{7}{|c|}{ Capsule Fraction } \\
\hline Ag-110m & 7.73E-04 & $1.22 \mathrm{E}-03$ & $8.76 \mathrm{E}-04$ & 8.34E-04 & $3.71 \mathrm{E}-03$ & 0 \\
\hline Cs-134 & $1.31 \mathrm{E}-04$ & $3.47 \mathrm{E}-05$ & 4.93E-06 & $2.52 \mathrm{E}-05$ & $1.96 \mathrm{E}-04$ & $1.96 \mathrm{E}-04$ \\
\hline Cs-137 & $2.26 \mathrm{E}-04$ & $2.92 \mathrm{E}-05$ & $2.56 \mathrm{E}-06$ & $3.41 \mathrm{E}-05$ & 2.91E-04 & $2.91 \mathrm{E}-04$ \\
\hline Ce-144 & $1.69 \mathrm{E}-06$ & $1.52 \mathrm{E}-06$ & $3.80 \mathrm{E}-06$ & $7.55 \mathrm{E}-07$ & 7.77E-06 & 0 \\
\hline Eu-154 & $1.37 \mathrm{E}-05$ & $8.58 \mathrm{E}-07$ & $1.70 \mathrm{E}-05$ & 4.17E-05 & 7.33E-05 & 0 \\
\hline Sr-90 & $8.62 \mathrm{E}-07$ & $\mathrm{~b}$ & $1.84 \mathrm{E}-07$ & $2.74 \mathrm{E}-06$ & $3.78 \mathrm{E}-06$ & $3.78 \mathrm{E}-06$ \\
\hline \multicolumn{7}{|c|}{ Particle Equivalents } \\
\hline Ag-110m & $5.85 \mathrm{E}+00$ & $9.27 \mathrm{E}+00$ & $6.63 \mathrm{E}+00$ & $6.31 \mathrm{E}+00$ & $2.81 \mathrm{E}+01$ & 0 \\
\hline Cs-134 & $9.91 \mathrm{E}-01$ & $2.63 \mathrm{E}-01$ & $3.73 \mathrm{E}-02$ & $1.91 \mathrm{E}-01$ & $1.48 \mathrm{E}+00$ & $1.48 \mathrm{E}+00$ \\
\hline Cs-137 & $1.71 \mathrm{E}+00$ & $2.21 \mathrm{E}-01$ & $1.94 \mathrm{E}-02$ & $2.58 \mathrm{E}-01$ & $2.21 \mathrm{E}+00$ & $2.21 \mathrm{E}+00$ \\
\hline $\mathrm{Ce}-144$ & $1.28 \mathrm{E}-02$ & $1.15 \mathrm{E}-02$ & $2.88 \mathrm{E}-02$ & $5.71 \mathrm{E}-03$ & $5.88 \mathrm{E}-02$ & 0 \\
\hline Eu-154 & $1.04 \mathrm{E}-01$ & $6.49 \mathrm{E}-03$ & 1.29E-01 & $3.16 \mathrm{E}-01$ & $5.55 \mathrm{E}-01$ & 0 \\
\hline Sr-90 & $6.52 \mathrm{E}-03$ & $\mathrm{~b}$ & $1.39 \mathrm{E}-03$ & $2.07 \mathrm{E}-02$ & $2.86 \mathrm{E}-02$ & $2.86 \mathrm{E}-02$ \\
\hline
\end{tabular}


Table 7. Inventories in sink ring, total hardware (sum from Table 6), and available inventory measured outside of the fuel. Inner and outer rings were not measured for this intact fuel body. Errors are given based on propagation of uncertainty across all the sum of all measured values. Shaded cells are based entirely on MDAs or cases where MDAs account for $>50 \%$ of a sum of MDAs and measured values.

\begin{tabular}{|c|c|c|c|c|c|c|c|c|}
\hline Capsule 2 & $\begin{array}{c}\text { Inner } \\
\text { Ring }\end{array}$ & $\begin{array}{c}\text { Outer } \\
\text { Ring }\end{array}$ & $\begin{array}{l}\text { Sink } \\
\text { Ring } \\
\end{array}$ & $\begin{array}{l}\text { Hardware } \\
\text { (measured } \\
+ \text { MDA) }\end{array}$ & $\begin{array}{l}\text { Grand } \\
\text { Total } \\
\text { (measured } \\
+ \text { MDA) }\end{array}$ & $\begin{array}{c}\text { Grand } \\
\text { Total } \\
\text { (measured } \\
\text { only) }\end{array}$ & $\begin{array}{c}\text { Error } \\
\text { (\% minus) }\end{array}$ & $\begin{array}{c}\text { Error } \\
\text { (\% plus) }\end{array}$ \\
\hline $\begin{array}{c}\text { Ring } \\
\text { Material }\end{array}$ & Matrix & PCEA & PCEA & $\mathrm{N} / \mathrm{A}$ & N/A & N/A & N/A & N/A \\
\hline $\begin{array}{c}\text { TAVA } \\
\text { Temp }\left({ }^{\circ} \mathrm{C}\right)\end{array}$ & 934 & 859 & 609 & N/A & N/A & N/A & $\mathrm{N} / \mathrm{A}$ & N/A \\
\hline \multicolumn{9}{|c|}{ Decay-Corrected Activity (Bq) } \\
\hline $\mathrm{Ag}-110 \mathrm{~m}$ & $\mathrm{~N} / \mathrm{A}$ & N/A & $3.93 \mathrm{E}+05$ & $5.26 \mathrm{E}+05$ & $9.19 \mathrm{E}+05$ & $0.00 \mathrm{E}+00$ & - & - \\
\hline Cs-134 & $\mathrm{N} / \mathrm{A}$ & $\mathrm{N} / \mathrm{A}$ & $5.99 \mathrm{E}+06$ & $3.29 \mathrm{E}+06$ & $9.27 \mathrm{E}+06$ & $9.27 \mathrm{E}+06$ & $4.1 \%$ & $4.1 \%$ \\
\hline Cs-137 & $\mathrm{N} / \mathrm{A}$ & $\mathrm{N} / \mathrm{A}$ & $1.96 \mathrm{E}+07$ & $5.88 \mathrm{E}+06$ & $2.55 \mathrm{E}+07$ & $2.55 \mathrm{E}+07$ & $4.1 \%$ & $4.1 \%$ \\
\hline $\mathrm{Ce}-144$ & $\mathrm{~N} / \mathrm{A}$ & $\mathrm{N} / \mathrm{A}$ & $3.67 \mathrm{E}+06$ & $2.45 \mathrm{E}+06$ & $6.13 \mathrm{E}+06$ & $0.00 \mathrm{E}+00$ & - & - \\
\hline Eu-154 & $\mathrm{N} / \mathrm{A}$ & $\mathrm{N} / \mathrm{A}$ & $3.72 \mathrm{E}+04$ & $4.11 \mathrm{E}+04$ & $7.83 \mathrm{E}+04$ & $0.00 \mathrm{E}+00$ & - & - \\
\hline Sr-90 & a & a & $6.48 \mathrm{E}+04$ & $6.83 \mathrm{E}+04$ & $1.33 \mathrm{E}+05$ & $1.33 \mathrm{E}+05$ & $1.7 \%$ & $1.7 \%$ \\
\hline \multicolumn{9}{|c|}{ Capsule Fraction } \\
\hline $\mathrm{Ag}-110 \mathrm{~m}$ & N/A & N/A & $2.77 \mathrm{E}-03$ & $3.71 \mathrm{E}-03$ & $6.47 \mathrm{E}-03$ & $0.00 \mathrm{E}+00$ & $0.0 \%$ & $0.0 \%$ \\
\hline Cs-134 & N/A & N/A & $3.57 \mathrm{E}-04$ & $1.96 \mathrm{E}-04$ & $5.52 \mathrm{E}-04$ & $5.52 \mathrm{E}-04$ & $4.1 \%$ & $4.1 \%$ \\
\hline Cs-137 & $\mathrm{N} / \mathrm{A}$ & N/A & $9.70 \mathrm{E}-04$ & $2.91 \mathrm{E}-04$ & $1.26 \mathrm{E}-03$ & $1.26 \mathrm{E}-03$ & $4.1 \%$ & $4.1 \%$ \\
\hline $\mathrm{Ce}-144$ & $\mathrm{~N} / \mathrm{A}$ & $\mathrm{N} / \mathrm{A}$ & $1.16 \mathrm{E}-05$ & 7.77E-06 & $1.94 \mathrm{E}-05$ & $0.00 \mathrm{E}+00$ & - & - \\
\hline Eu-154 & $\mathrm{N} / \mathrm{A}$ & N/A & $6.63 \mathrm{E}-05$ & 7.33E-05 & $1.40 \mathrm{E}-04$ & $0.00 \mathrm{E}+00$ & 一 & 一 \\
\hline Sr-90 & a & a & $3.59 \mathrm{E}-06$ & $3.78 \mathrm{E}-06$ & 7.37E-06 & 7.37E-06 & $1.7 \%$ & $1.7 \%$ \\
\hline \multicolumn{9}{|c|}{ Particle Equivalents } \\
\hline $\mathrm{Ag}-110 \mathrm{~m}$ & $\mathrm{~N} / \mathrm{A}$ & $\mathrm{N} / \mathrm{A}$ & $2.09 \mathrm{E}+01$ & $2.81 \mathrm{E}+01$ & $4.90 \mathrm{E}+01$ & $0.00 \mathrm{E}+00$ & 一 & 一 \\
\hline Cs-134 & N/A & $\mathrm{N} / \mathrm{A}$ & $2.70 \mathrm{E}+00$ & $1.48 \mathrm{E}+00$ & $4.18 \mathrm{E}+00$ & $4.18 \mathrm{E}+00$ & $4.1 \%$ & $4.1 \%$ \\
\hline Cs-137 & N/A & N/A & $7.34 \mathrm{E}+00$ & $2.21 \mathrm{E}+00$ & $9.55 \mathrm{E}+00$ & $9.55 \mathrm{E}+00$ & $4.1 \%$ & $4.1 \%$ \\
\hline $\mathrm{Ce}-144$ & N/A & N/A & $8.81 \mathrm{E}-02$ & $5.88 \mathrm{E}-02$ & $1.47 \mathrm{E}-01$ & $0.00 \mathrm{E}+00$ & - & - \\
\hline Eu-154 & N/A & N/A & $5.02 \mathrm{E}-01$ & $5.55 \mathrm{E}-01$ & $1.06 \mathrm{E}+00$ & $0.00 \mathrm{E}+00$ & - & - \\
\hline Sr-90 & a & a & $2.72 \mathrm{E}-02$ & $2.86 \mathrm{E}-02$ & $5.58 \mathrm{E}-02$ & $5.58 \mathrm{E}-02$ & $1.7 \%$ & $1.7 \%$ \\
\hline \multicolumn{9}{|c|}{$\begin{array}{l}\text { N/A not applicable. Or, in the case of the inner and outer rings: not available because the Capsule } 2 \text { fuel body was retained } \\
\text { intact. } \\
\text { N/D not detected on PGS, no MDAs determined. } \\
\text { a. }\end{array}$} \\
\hline
\end{tabular}




\subsection{Capsule 3}

Capsule 3 was a standard-type capsule, and Table 8 shows the activities, capsule fractions, and particle equivalents for selected isotopes measured on the capsule hardware. Table 9 represents the entire mass balance for Capsule 3 (inner ring, outer ring, sink ring, foils, felts, spacers, and through tubes).

Table 8. Summary of inventories of select isotopes on Capsule 3 hardware. Shaded cells are based entirely on MDAs or cases where MDAs account for $>50 \%$ of a sum of MDAs and measured values.

\begin{tabular}{|c|c|c|c|c|c|c|}
\hline Capsule 3 & Foils & Felts $^{\mathrm{a}}$ & Spacers & $\begin{array}{c}\text { Through } \\
\text { Tubes }\end{array}$ & $\begin{array}{c}\text { Total } \\
\text { (measured } \\
+ \text { MDA) } \\
\end{array}$ & $\begin{array}{c}\text { Total } \\
\text { (measured } \\
\text { only) }\end{array}$ \\
\hline \multicolumn{7}{|c|}{ Decay-Corrected Activity (Bq) } \\
\hline Ag-110m & $2.14 \mathrm{E}+05$ & $2.56 \mathrm{E}+06$ & $5.23 \mathrm{E}+06$ & $1.94 \mathrm{E}+05$ & $8.20 \mathrm{E}+06$ & $7.79 \mathrm{E}+06$ \\
\hline Cs-134 & $2.47 \mathrm{E}+06$ & $4.09 \mathrm{E}+06$ & $2.84 \mathrm{E}+05$ & $4.82 \mathrm{E}+06$ & $1.17 \mathrm{E}+07$ & $1.17 \mathrm{E}+07$ \\
\hline Cs-137 & $6.83 \mathrm{E}+06$ & $3.68 \mathrm{E}+06$ & $3.85 \mathrm{E}+05$ & $6.15 \mathrm{E}+06$ & $1.71 \mathrm{E}+07$ & $1.71 \mathrm{E}+07$ \\
\hline Ce-144 & $2.81 \mathrm{E}+06$ & $7.03 \mathrm{E}+05$ & $3.86 \mathrm{E}+06$ & $3.91 \mathrm{E}+05$ & $7.76 \mathrm{E}+06$ & $2.81 \mathrm{E}+06$ \\
\hline Eu-154 & $2.38 \mathrm{E}+05$ & $8.88 \mathrm{E}+02$ & $2.04 \mathrm{E}+04$ & $2.87 \mathrm{E}+04$ & $2.88 \mathrm{E}+05$ & $2.38 \mathrm{E}+05$ \\
\hline Sr-90 & $6.54 \mathrm{E}+06$ & $\mathrm{~b}$ & $4.11 \mathrm{E}+04$ & $1.88 \mathrm{E}+04$ & $6.60 \mathrm{E}+06$ & $6.60 \mathrm{E}+06$ \\
\hline \multicolumn{7}{|c|}{ Capsule Fraction } \\
\hline $\mathrm{Ag}-110 \mathrm{~m}$ & 7.79E-04 & $9.31 \mathrm{E}-03$ & $1.90 \mathrm{E}-02$ & 7.06E-04 & $2.98 \mathrm{E}-02$ & $2.83 \mathrm{E}-02$ \\
\hline Cs-134 & $9.05 \mathrm{E}-05$ & $1.50 \mathrm{E}-04$ & $1.04 \mathrm{E}-05$ & $1.77 \mathrm{E}-04$ & 4.27E-04 & 4.27E-04 \\
\hline Cs-137 & $2.71 \mathrm{E}-04$ & $1.46 \mathrm{E}-04$ & $1.53 \mathrm{E}-05$ & $2.44 \mathrm{E}-04$ & $6.75 \mathrm{E}-04$ & $6.75 \mathrm{E}-04$ \\
\hline $\mathrm{Ce}-144$ & 7.32E-06 & $1.83 \mathrm{E}-06$ & $1.00 \mathrm{E}-05$ & $1.02 \mathrm{E}-06$ & $2.02 \mathrm{E}-05$ & 7.32E-06 \\
\hline Eu-154 & $2.67 \mathrm{E}-04$ & $9.95 \mathrm{E}-07$ & 2.29E-05 & $3.22 \mathrm{E}-05$ & 3.23E-04 & $2.67 \mathrm{E}-04$ \\
\hline Sr-90 & $2.97 \mathrm{E}-04$ & $\mathrm{~b}$ & $1.86 \mathrm{E}-06$ & $8.52 \mathrm{E}-07$ & $3.00 \mathrm{E}-04$ & $3.00 \mathrm{E}-04$ \\
\hline \multicolumn{7}{|c|}{ Particle Equivalents } \\
\hline $\mathrm{Ag}-110 \mathrm{~m}$ & $5.90 \mathrm{E}+00$ & $7.04 \mathrm{E}+01$ & $1.44 \mathrm{E}+02$ & $5.34 \mathrm{E}+00$ & $2.26 \mathrm{E}+02$ & $2.14 \mathrm{E}+02$ \\
\hline Cs-134 & $6.85 \mathrm{E}-01$ & $1.13 \mathrm{E}+00$ & $7.88 \mathrm{E}-02$ & $1.34 \mathrm{E}+00$ & $3.23 \mathrm{E}+00$ & $3.23 \mathrm{E}+00$ \\
\hline Cs-137 & $2.05 \mathrm{E}+00$ & $1.10 \mathrm{E}+00$ & $1.15 \mathrm{E}-01$ & $1.84 \mathrm{E}+00$ & $5.11 \mathrm{E}+00$ & $5.11 \mathrm{E}+00$ \\
\hline $\mathrm{Ce}-144$ & $5.54 \mathrm{E}-02$ & $1.39 \mathrm{E}-02$ & $7.60 \mathrm{E}-02$ & $7.70 \mathrm{E}-03$ & $1.53 \mathrm{E}-01$ & $5.54 \mathrm{E}-02$ \\
\hline Eu-154 & $2.02 \mathrm{E}+00$ & $7.53 \mathrm{E}-03$ & $1.73 \mathrm{E}-01$ & $2.44 \mathrm{E}-01$ & $2.44 \mathrm{E}+00$ & $2.02 \mathrm{E}+00$ \\
\hline Sr-90 & $2.25 \mathrm{E}+00$ & $\mathrm{~b}$ & $1.41 \mathrm{E}-02$ & $6.45 \mathrm{E}-03$ & $2.27 \mathrm{E}+00$ & $2.27 \mathrm{E}+00$ \\
\hline
\end{tabular}


Table 9. Inventories in capsule rings, total hardware (sum from Table 8), and total inventory measured outside of the fuel. Errors are given based on propagation of uncertainty across all the sum of all measured values. Shaded cells are based entirely on MDAs or cases where MDAs account for $>50 \%$ of a sum of MDAs and measured values.

\begin{tabular}{|c|c|c|c|c|c|c|c|c|}
\hline Capsule 3 & $\begin{array}{c}\text { Inner } \\
\text { Ring }\end{array}$ & $\begin{array}{c}\text { Outer } \\
\text { Ring }\end{array}$ & $\begin{array}{l}\text { Sink } \\
\text { Ring }\end{array}$ & $\begin{array}{c}\text { Hardware } \\
\text { (measured } \\
+ \text { MDA) }\end{array}$ & $\begin{array}{c}\text { Grand } \\
\text { Total } \\
\text { (measured } \\
+ \text { MDA) } \\
\end{array}$ & $\begin{array}{c}\begin{array}{c}\text { Grand } \\
\text { Total } \\
\text { (measured } \\
\text { only) }\end{array} \\
\end{array}$ & $\begin{array}{l}\text { Error } \\
(\% \text { minus }) \\
\end{array}$ & $\begin{array}{c}\text { Error } \\
(\% \text { plus }) \\
\end{array}$ \\
\hline $\begin{array}{l}\text { Ring } \\
\text { Material }\end{array}$ & PCEA & PCEA & PCEA & N/A & N/A & $\mathrm{N} / \mathrm{A}$ & N/A & N/A \\
\hline $\begin{array}{l}\text { TAVA } \\
\text { Temp }\left({ }^{\circ} \mathrm{C}\right)\end{array}$ & 1026 & 962 & 539 & N/A & N/A & N/A & $\mathrm{N} / \mathrm{A}$ & N/A \\
\hline \multicolumn{9}{|c|}{ Decay-Corrected Activity (Bq) } \\
\hline $\mathrm{Ag}-110 \mathrm{~m}$ & $1.46 \mathrm{E}+03$ & $5.22 \mathrm{E}+03$ & $1.33 \mathrm{E}+08$ & $8.20 \mathrm{E}+06$ & $1.41 \mathrm{E}+08$ & $1.41 \mathrm{E}+08$ & $4.1 \%$ & $4.1 \%$ \\
\hline Cs-134 & $2.18 \mathrm{E}+01$ & $1.84 \mathrm{E}+01$ & $8.81 \mathrm{E}+07$ & $1.17 \mathrm{E}+07$ & $9.97 \mathrm{E}+07$ & $9.97 \mathrm{E}+07$ & $3.7 \%$ & $3.7 \%$ \\
\hline Cs-137 & $2.85 \mathrm{E}+01$ & $2.19 \mathrm{E}+01$ & $8.55 \mathrm{E}+07$ & $1.71 \mathrm{E}+07$ & $1.03 \mathrm{E}+08$ & $1.03 \mathrm{E}+08$ & $3.3 \%$ & $3.3 \%$ \\
\hline $\mathrm{Ce}-144$ & $\mathrm{~N} / \mathrm{D}$ & $\mathrm{N} / \mathrm{D}$ & $3.54 \mathrm{E}+06$ & $7.76 \mathrm{E}+06$ & $1.13 \mathrm{E}+07$ & $2.81 \mathrm{E}+06$ & $19.8 \%$ & $19.8 \%$ \\
\hline Eu-154 & $1.63 \mathrm{E}+02$ & $4.00 \mathrm{E}+01$ & $1.18 \mathrm{E}+05$ & $2.88 \mathrm{E}+05$ & $4.06 \mathrm{E}+05$ & $2.38 \mathrm{E}+05$ & $4.5 \%$ & $9.2 \%$ \\
\hline Sr-90 & a & a & $1.86 \mathrm{E}+05$ & $6.60 \mathrm{E}+06$ & $6.79 \mathrm{E}+06$ & $6.79 \mathrm{E}+06$ & $1.1 \%$ & $1.1 \%$ \\
\hline \multicolumn{9}{|c|}{ Capsule Fraction } \\
\hline $\mathrm{Ag}-110 \mathrm{~m}$ & $3.94 \mathrm{E}-02$ & $1.41 \mathrm{E}-01$ & 4.84E-01 & $2.98 \mathrm{E}-02$ & $6.95 \mathrm{E}-01$ & $6.93 \mathrm{E}-01$ & $4.1 \%$ & $4.1 \%$ \\
\hline Cs-134 & $5.90 \mathrm{E}-04$ & 4.97E-04 & $3.23 \mathrm{E}-03$ & $4.27 \mathrm{E}-04$ & 4.74E-03 & $4.74 \mathrm{E}-03$ & $3.7 \%$ & $3.7 \%$ \\
\hline Cs-137 & 7.71E-04 & $5.92 \mathrm{E}-04$ & 3.39E-03 & $6.75 \mathrm{E}-04$ & $5.42 \mathrm{E}-03$ & $5.42 \mathrm{E}-03$ & $3.3 \%$ & $3.3 \%$ \\
\hline $\mathrm{Ce}-144$ & $\mathrm{~N} / \mathrm{D}$ & $\mathrm{N} / \mathrm{D}$ & $9.23 \mathrm{E}-06$ & $2.02 \mathrm{E}-05$ & $2.94 \mathrm{E}-05$ & $7.32 \mathrm{E}-06$ & $19.8 \%$ & $19.8 \%$ \\
\hline Eu-154 & $4.40 \mathrm{E}-03$ & $1.08 \mathrm{E}-03$ & $1.32 \mathrm{E}-04$ & $3.23 \mathrm{E}-04$ & $5.93 \mathrm{E}-03$ & 4.67E-03 & $4.5 \%$ & $9.2 \%$ \\
\hline Sr-90 & $\mathrm{a}$ & $\mathrm{a}$ & $8.45 \mathrm{E}-06$ & $3.00 \mathrm{E}-04$ & $3.08 \mathrm{E}-04$ & $3.08 \mathrm{E}-04$ & $1.1 \%$ & $1.1 \%$ \\
\hline \multicolumn{9}{|c|}{ Particle Equivalents } \\
\hline $\mathrm{Ag}-110 \mathrm{~m}$ & $2.98 \mathrm{E}+02$ & $1.07 \mathrm{E}+03$ & $3.67 \mathrm{E}+03$ & $2.26 \mathrm{E}+02$ & $5.26 \mathrm{E}+03$ & $5.25 \mathrm{E}+03$ & $4.1 \%$ & $4.1 \%$ \\
\hline Cs-134 & $4.47 \mathrm{E}+00$ & $3.76 \mathrm{E}+00$ & $2.44 \mathrm{E}+01$ & $3.23 \mathrm{E}+00$ & $3.59 \mathrm{E}+01$ & $3.59 \mathrm{E}+01$ & $3.7 \%$ & $3.7 \%$ \\
\hline Cs-137 & $5.83 \mathrm{E}+00$ & $4.48 \mathrm{E}+00$ & $2.56 \mathrm{E}+01$ & $5.11 \mathrm{E}+00$ & $4.11 \mathrm{E}+01$ & $4.11 \mathrm{E}+01$ & $3.3 \%$ & $3.3 \%$ \\
\hline Ce-144 & $\mathrm{N} / \mathrm{D}$ & N/D & $6.99 \mathrm{E}-02$ & $1.53 \mathrm{E}-01$ & $2.23 \mathrm{E}-01$ & $5.54 \mathrm{E}-02$ & $19.8 \%$ & $19.8 \%$ \\
\hline Eu-154 & $3.33 \mathrm{E}+01$ & $8.17 \mathrm{E}+00$ & $9.97 \mathrm{E}-01$ & $2.44 \mathrm{E}+00$ & $4.49 \mathrm{E}+01$ & $3.53 \mathrm{E}+01$ & $4.5 \%$ & $9.2 \%$ \\
\hline Sr-90 & $\mathrm{a}$ & $\mathrm{a}$ & $6.40 \mathrm{E}-02$ & $2.27 \mathrm{E}+00$ & $2.33 \mathrm{E}+00$ & $2.33 \mathrm{E}+00$ & $1.1 \%$ & $1.1 \%$ \\
\hline \multicolumn{9}{|c|}{$\begin{array}{l}\text { N/A not applicable. } \\
\text { N/D not detected on PGS, no MDAs determined. } \\
\text { a. requires destructive analysis to measure. }\end{array}$} \\
\hline
\end{tabular}




\subsection{Capsule 4}

Capsule 4 was a fuel body capsule that was disassembled to access the compacts and inner and outer rings. Table 10 shows the activities, capsule fractions, and particle equivalents for selected isotopes measured on the capsule hardware. Note that the foils and felts were not recovered from Capsule 4. It is possible that the foils and felts contained significant activity, comparable to that of the spacers and/or rings. Table 11 represents the total mass balance for Capsule 4 (inner ring, outer ring, sink ring, foils, felts, spacers, and through tubes). Oxidation of the sink ring left behind flakes of material with a total residual mass of $24.64 \mathrm{~g}$. A total of $0.573 \mathrm{~g}$ of this residual was spread across four different mounts for elemental identification by SEM-EDS. Primarily antimony and tin were detected.

Table 10. Summary of inventories of select isotopes on Capsule 4 hardware. Shaded cells are based entirely on MDAs or cases where MDAs account for $>50 \%$ of a sum of MDAs and measured values.

\begin{tabular}{|c|c|c|c|c|c|c|}
\hline Capsule 4 & Foils & Felts & Spacers & $\begin{array}{c}\text { Through } \\
\text { Tubes }\end{array}$ & $\begin{array}{c}\text { Total } \\
\text { (measured } \\
+ \text { MDA) } \\
\end{array}$ & $\begin{array}{c}\text { Total } \\
\text { (measured } \\
\text { only) }\end{array}$ \\
\hline \multicolumn{7}{|c|}{ Decay-Corrected Activity (Bq) } \\
\hline Ag-110m & $\mathrm{N} / \mathrm{A}$ & $\mathrm{N} / \mathrm{A}$ & $3.47 \mathrm{E}+05$ & $3.00 \mathrm{E}+05$ & $6.47 \mathrm{E}+05$ & $3.00 \mathrm{E}+05$ \\
\hline Cs-134 & $\mathrm{N} / \mathrm{A}$ & $\mathrm{N} / \mathrm{A}$ & $2.85 \mathrm{E}+04$ & $1.37 \mathrm{E}+05$ & $1.65 \mathrm{E}+05$ & $1.37 \mathrm{E}+05$ \\
\hline Cs-137 & $\mathrm{N} / \mathrm{A}$ & $\mathrm{N} / \mathrm{A}$ & $1.62 \mathrm{E}+04$ & $1.65 \mathrm{E}+05$ & $1.81 \mathrm{E}+05$ & $1.65 \mathrm{E}+05$ \\
\hline Ce-144 & $\mathrm{N} / \mathrm{A}$ & $\mathrm{N} / \mathrm{A}$ & $3.94 \mathrm{E}+06$ & $2.38 \mathrm{E}+05$ & $4.18 \mathrm{E}+06$ & 0 \\
\hline Eu-154 & $\mathrm{N} / \mathrm{A}$ & $\mathrm{N} / \mathrm{A}$ & $1.53 \mathrm{E}+04$ & $1.17 \mathrm{E}+04$ & $2.70 \mathrm{E}+04$ & 0 \\
\hline Sr-90 & $\mathrm{N} / \mathrm{A}$ & $\mathrm{N} / \mathrm{A}$ & $2.54 \mathrm{E}+03$ & $1.96 \mathrm{E}+04$ & $2.21 \mathrm{E}+04$ & $2.21 \mathrm{E}+04$ \\
\hline \multicolumn{7}{|c|}{ Capsule Fraction } \\
\hline $\mathrm{Ag}-110 \mathrm{~m}$ & $\mathrm{~N} / \mathrm{A}$ & $\mathrm{N} / \mathrm{A}$ & $8.77 \mathrm{E}-04$ & $7.57 \mathrm{E}-04$ & $1.63 \mathrm{E}-03$ & 7.57E-04 \\
\hline Cs-134 & $\mathrm{N} / \mathrm{A}$ & $\mathrm{N} / \mathrm{A}$ & $7.94 \mathrm{E}-07$ & $3.82 \mathrm{E}-06$ & 4.61E-06 & $3.82 \mathrm{E}-06$ \\
\hline Cs-137 & $\mathrm{N} / \mathrm{A}$ & $\mathrm{N} / \mathrm{A}$ & $5.69 \mathrm{E}-07$ & $5.79 \mathrm{E}-06$ & $6.36 \mathrm{E}-06$ & $5.79 \mathrm{E}-06$ \\
\hline $\mathrm{Ce}-144$ & N/A & N/A & $9.25 \mathrm{E}-06$ & $5.60 \mathrm{E}-07$ & $9.81 \mathrm{E}-06$ & 0 \\
\hline Eu-154 & $\mathrm{N} / \mathrm{A}$ & $\mathrm{N} / \mathrm{A}$ & $1.37 \mathrm{E}-05$ & $1.04 \mathrm{E}-05$ & $2.41 \mathrm{E}-05$ & 0 \\
\hline Sr-90 & $\mathrm{N} / \mathrm{A}$ & $\mathrm{N} / \mathrm{A}$ & $1.03 \mathrm{E}-07$ & 7.98E-07 & $9.02 \mathrm{E}-07$ & $9.02 \mathrm{E}-07$ \\
\hline \multicolumn{7}{|c|}{ Particle Equivalents } \\
\hline Ag-110m & $\mathrm{N} / \mathrm{A}$ & $\mathrm{N} / \mathrm{A}$ & $6.64 \mathrm{E}+00$ & $5.73 \mathrm{E}+00$ & $1.24 \mathrm{E}+01$ & $5.73 \mathrm{E}+00$ \\
\hline Cs-134 & $\mathrm{N} / \mathrm{A}$ & $\mathrm{N} / \mathrm{A}$ & $6.01 \mathrm{E}-03$ & 2.89E-02 & 3.49E-02 & $2.89 \mathrm{E}-02$ \\
\hline Cs-137 & $\mathrm{N} / \mathrm{A}$ & N/A & 4.31E-03 & 4.38E-02 & 4.81E-02 & $4.38 \mathrm{E}-02$ \\
\hline $\mathrm{Ce}-144$ & $\mathrm{~N} / \mathrm{A}$ & $\mathrm{N} / \mathrm{A}$ & $7.00 \mathrm{E}-02$ & 4.24E-03 & 7.42E-02 & 0 \\
\hline Eu-154 & $\mathrm{N} / \mathrm{A}$ & N/A & $1.03 \mathrm{E}-01$ & $7.88 \mathrm{E}-02$ & $1.82 \mathrm{E}-01$ & 0 \\
\hline Sr-90 & $\mathrm{N} / \mathrm{A}$ & $\mathrm{N} / \mathrm{A}$ & $7.82 \mathrm{E}-04$ & $6.04 \mathrm{E}-03$ & $6.82 \mathrm{E}-03$ & $6.82 \mathrm{E}-03$ \\
\hline
\end{tabular}


Table 11. Inventories in capsule rings, total hardware (sum from Table 10), and total inventory measured outside of the fuel. Errors are given based on propagation of uncertainty across all the sum of all measured values. Shaded cells are based entirely on MDAs or cases where MDAs account for $>50 \%$ of a sum of MDAs and measured values.

\begin{tabular}{|c|c|c|c|c|c|c|c|c|}
\hline Capsule 4 & $\begin{array}{c}\text { Inner } \\
\text { Ring }\end{array}$ & $\begin{array}{c}\text { Outer } \\
\text { Ring }\end{array}$ & $\begin{array}{l}\text { Sink } \\
\text { Ring }\end{array}$ & $\begin{array}{c}\text { Hardware } \\
\text { (measured } \\
+ \text { MDA) }\end{array}$ & $\begin{array}{c}\text { Grand } \\
\text { Total } \\
\text { (measured } \\
+ \text { MDA } \\
\end{array}$ & $\begin{array}{c}\text { Grand } \\
\text { Total } \\
\text { (measured } \\
\text { only) }\end{array}$ & $\begin{array}{c}\text { Error } \\
(\% \text { minus }) \\
\end{array}$ & $\begin{array}{c}\text { Error } \\
\text { (\% plus) }\end{array}$ \\
\hline $\begin{array}{c}\text { Ring } \\
\text { Material }\end{array}$ & Matrix & PCEA & PCEA & N/A & $\mathrm{N} / \mathrm{A}$ & N/A & N/A & N/A \\
\hline $\begin{array}{c}\text { TAVA } \\
\text { Temp }\left({ }^{\circ} \mathrm{C}\right)\end{array}$ & 820 & 708 & 582 & N/A & N/A & N/A & N/A & $\mathrm{N} / \mathrm{A}$ \\
\hline \multicolumn{9}{|c|}{ Decay-Corrected Activity (Bq) } \\
\hline $\mathrm{Ag}-110 \mathrm{~m}$ & $2.70 \mathrm{E}+07$ & $7.88 \mathrm{E}+05$ & $1.23 \mathrm{E}+06$ & $6.47 \mathrm{E}+05$ & $2.96 \mathrm{E}+07$ & $2.93 \mathrm{E}+07$ & $4.0 \%$ & $18.6 \%$ \\
\hline Cs-134 & $3.09 \mathrm{E}+08$ & $2.83 \mathrm{E}+07$ & $4.29 \mathrm{E}+06$ & $1.65 \mathrm{E}+05$ & $3.42 \mathrm{E}+08$ & $3.42 \mathrm{E}+08$ & $0.3 \%$ & $0.3 \%$ \\
\hline Cs-137 & $2.39 \mathrm{E}+08$ & $2.11 \mathrm{E}+07$ & $1.59 \mathrm{E}+07$ & $1.81 \mathrm{E}+05$ & $2.76 \mathrm{E}+08$ & $2.76 \mathrm{E}+08$ & $0.4 \%$ & $0.4 \%$ \\
\hline $\mathrm{Ce}-144$ & $\mathrm{~N} / \mathrm{D}$ & $\mathrm{N} / \mathrm{D}$ & $8.94 \mathrm{E}+06$ & $4.18 \mathrm{E}+06$ & $1.31 \mathrm{E}+07$ & $0.00 \mathrm{E}+00$ & - & - \\
\hline Eu-154 & $1.04 \mathrm{E}+06$ & $1.01 \mathrm{E}+06$ & $6.15 \mathrm{E}+04$ & $2.70 \mathrm{E}+04$ & $2.14 \mathrm{E}+06$ & $0.00 \mathrm{E}+00$ & - & - \\
\hline Sr-90 & a & a & $2.29 \mathrm{E}+05$ & $2.21 \mathrm{E}+04$ & $2.51 \mathrm{E}+05$ & $2.51 \mathrm{E}+05$ & $1.7 \%$ & $1.7 \%$ \\
\hline \multicolumn{9}{|c|}{ Capsule Fraction } \\
\hline $\mathrm{Ag}-110 \mathrm{~m}$ & $6.81 \mathrm{E}-02$ & $1.99 \mathrm{E}-03$ & $3.10 \mathrm{E}-03$ & $1.63 \mathrm{E}-03$ & $7.49 \mathrm{E}-02$ & $7.40 \mathrm{E}-02$ & $4.0 \%$ & $18.6 \%$ \\
\hline Cs-134 & 8.61E-03 & 7.89E-04 & $1.20 \mathrm{E}-04$ & 4.61E-06 & $9.52 \mathrm{E}-03$ & $9.52 \mathrm{E}-03$ & $0.3 \%$ & $0.3 \%$ \\
\hline Cs-137 & $8.38 \mathrm{E}-03$ & 7.38E-04 & $5.57 \mathrm{E}-04$ & $6.36 \mathrm{E}-06$ & $9.68 \mathrm{E}-03$ & $9.68 \mathrm{E}-03$ & $0.4 \%$ & $0.4 \%$ \\
\hline $\mathrm{Ce}-144$ & $\mathrm{~N} / \mathrm{D}$ & $\mathrm{N} / \mathrm{D}$ & $2.10 \mathrm{E}-05$ & $9.81 \mathrm{E}-06$ & $3.08 \mathrm{E}-05$ & $0.00 \mathrm{E}+00$ & - & - \\
\hline Eu-154 & $9.25 \mathrm{E}-04$ & 8.97E-04 & $5.48 \mathrm{E}-05$ & $2.41 \mathrm{E}-05$ & $1.90 \mathrm{E}-03$ & $0.00 \mathrm{E}+00$ & 一 & - \\
\hline Sr-90 & a & $\mathrm{a}$ & $9.34 \mathrm{E}-06$ & $9.02 \mathrm{E}-07$ & $1.02 \mathrm{E}-05$ & $1.02 \mathrm{E}-05$ & $1.7 \%$ & $1.7 \%$ \\
\hline \multicolumn{9}{|c|}{ Particle Equivalents } \\
\hline $\mathrm{Ag}-110 \mathrm{~m}$ & $5.16 \mathrm{E}+02$ & $1.51 \mathrm{E}+01$ & $2.35 \mathrm{E}+01$ & $1.24 \mathrm{E}+01$ & $5.67 \mathrm{E}+02$ & $5.60 \mathrm{E}+02$ & $4.0 \%$ & $18.6 \%$ \\
\hline Cs-134 & $6.52 \mathrm{E}+01$ & $5.97 \mathrm{E}+00$ & $9.05 \mathrm{E}-01$ & $3.49 \mathrm{E}-02$ & $7.21 \mathrm{E}+01$ & $7.21 \mathrm{E}+01$ & $0.3 \%$ & $0.3 \%$ \\
\hline Cs-137 & $6.34 \mathrm{E}+01$ & $5.59 \mathrm{E}+00$ & $4.21 \mathrm{E}+00$ & $4.81 \mathrm{E}-02$ & $7.32 \mathrm{E}+01$ & $7.32 \mathrm{E}+01$ & $0.4 \%$ & $0.4 \%$ \\
\hline $\mathrm{Ce}-144$ & $\mathrm{~N} / \mathrm{D}$ & N/D & $1.59 \mathrm{E}-01$ & 7.42E-02 & $2.33 \mathrm{E}-01$ & $0.00 \mathrm{E}+00$ & - & - \\
\hline Eu-154 & $7.00 \mathrm{E}+00$ & $6.79 \mathrm{E}+00$ & 4.14E-01 & $1.82 \mathrm{E}-01$ & $1.44 \mathrm{E}+01$ & $0.00 \mathrm{E}+00$ & - & - \\
\hline Sr-90 & $\mathrm{a}$ & $\mathrm{a}$ & 7.07E-02 & $6.82 \mathrm{E}-03$ & $7.75 \mathrm{E}-02$ & 7.75E-02 & $1.7 \%$ & $1.7 \%$ \\
\hline \multicolumn{9}{|c|}{$\begin{array}{l}\text { N/A not applicable } \\
\text { N/D not detected on PGS, no MDAs determined } \\
\text { a. requires destructive analysis to measure }\end{array}$} \\
\hline
\end{tabular}




\subsection{Capsule 5}

Capsule 5 was a standard-type capsule. Table 12 shows the activities, capsule fractions, and particle equivalents for selected isotopes measured on the capsule hardware. Note that the spacers were not recovered for Capsule 5, and the spacers might have significant activity. Table 13 represents the entire mass balance for Capsule 5 (inner ring, outer ring, sink ring, foils, felts, spacers, and through tubes). Initial oxidation of the sink ring left behind $26.206 \mathrm{~g}$ of flakes of material that had a white color. After 2 leaches, significant gamma activity remained. A second burn was performed, followed by 4 additional leaches. After the $6^{\text {th }}$ and final leach, a total of $0.497 \mathrm{~g}$ of this residual was spread across three different mounts for elemental identification by SEM-EDS. Primarily antimony and tin were detected.

Table 12. Summary of inventories of select isotopes on Capsule 5 hardware. Shaded cells are based entirely on MDAs or cases where MDAs account for $>50 \%$ of a sum of MDAs and measured values.

\begin{tabular}{|c|c|c|c|c|c|c|}
\hline Capsule 5 & Foils & Felts $^{\mathbf{a}}$ & Spacers & $\begin{array}{c}\text { Through } \\
\text { Tubes }\end{array}$ & $\begin{array}{c}\text { Total } \\
\text { (measured } \\
+ \text { MDA) }\end{array}$ & $\begin{array}{c}\text { Total } \\
\text { (measured } \\
\text { only) }\end{array}$ \\
\hline \multicolumn{7}{|c|}{ Decay-Corrected Activity (Bq) } \\
\hline $\mathrm{Ag}-110 \mathrm{~m}$ & $1.10 \mathrm{E}+05$ & $6.66 \mathrm{E}+05$ & $\mathrm{~N} / \mathrm{A}$ & $3.55 \mathrm{E}+05$ & $1.13 \mathrm{E}+06$ & $3.55 \mathrm{E}+05$ \\
\hline Cs-134 & $4.93 \mathrm{E}+06$ & $1.85 \mathrm{E}+06$ & $\mathrm{~N} / \mathrm{A}$ & $4.54 \mathrm{E}+05$ & $7.24 \mathrm{E}+06$ & $7.24 \mathrm{E}+06$ \\
\hline Cs-137 & $5.27 \mathrm{E}+06$ & $1.18 \mathrm{E}+06$ & N/A & $4.19 \mathrm{E}+05$ & $6.87 \mathrm{E}+06$ & $6.87 \mathrm{E}+06$ \\
\hline $\mathrm{Ce}-144$ & $5.09 \mathrm{E}+06$ & $2.66 \mathrm{E}+05$ & $\mathrm{~N} / \mathrm{A}$ & $3.47 \mathrm{E}+05$ & $5.70 \mathrm{E}+06$ & $5.09 \mathrm{E}+06$ \\
\hline Eu-154 & $7.69 \mathrm{E}+03$ & $5.55 \mathrm{E}+02$ & N/A & $2.55 \mathrm{E}+04$ & $3.38 \mathrm{E}+04$ & $0.00 \mathrm{E}+00$ \\
\hline Sr-90 & $1.36 \mathrm{E}+04$ & $\mathrm{~b}$ & $\mathrm{~N} / \mathrm{A}$ & $2.90 \mathrm{E}+04$ & $4.26 \mathrm{E}+04$ & $4.26 \mathrm{E}+04$ \\
\hline \multicolumn{7}{|c|}{ Capsule Fraction } \\
\hline Ag-110m & $2.38 \mathrm{E}-04$ & $1.44 \mathrm{E}-03$ & $\mathrm{~N} / \mathrm{A}$ & 7.70E-04 & $2.45 \mathrm{E}-03$ & $7.70 \mathrm{E}-04$ \\
\hline Cs-134 & $1.23 \mathrm{E}-04$ & 4.64E-05 & N/A & $1.14 \mathrm{E}-05$ & $1.81 \mathrm{E}-04$ & $1.81 \mathrm{E}-04$ \\
\hline Cs-137 & $1.76 \mathrm{E}-04$ & $3.95 \mathrm{E}-05$ & $\mathrm{~N} / \mathrm{A}$ & $1.40 \mathrm{E}-05$ & $2.30 \mathrm{E}-04$ & $2.30 \mathrm{E}-04$ \\
\hline $\mathrm{Ce}-144$ & $1.15 \mathrm{E}-05$ & $6.01 \mathrm{E}-07$ & $\mathrm{~N} / \mathrm{A}$ & 7.82E-07 & $1.29 \mathrm{E}-05$ & $1.15 \mathrm{E}-05$ \\
\hline Eu-154 & $6.20 \mathrm{E}-06$ & $4.48 \mathrm{E}-07$ & N/A & $2.06 \mathrm{E}-05$ & $2.72 \mathrm{E}-05$ & $0.00 \mathrm{E}+00$ \\
\hline Sr-90 & $5.33 \mathrm{E}-07$ & $\mathrm{~b}$ & $\mathrm{~N} / \mathrm{A}$ & $1.14 \mathrm{E}-06$ & $1.67 \mathrm{E}-06$ & $1.67 \mathrm{E}-06$ \\
\hline \multicolumn{7}{|c|}{ Particle Equivalents } \\
\hline $\mathrm{Ag}-110 \mathrm{~m}$ & $1.80 \mathrm{E}+00$ & $1.09 \mathrm{E}+01$ & N/A & $5.82 \mathrm{E}+00$ & $1.85 \mathrm{E}+01$ & $5.82 \mathrm{E}+00$ \\
\hline Cs-134 & 9.34E-01 & $3.51 \mathrm{E}-01$ & $\mathrm{~N} / \mathrm{A}$ & 8.59E-02 & $1.37 \mathrm{E}+00$ & $1.37 \mathrm{E}+00$ \\
\hline Cs-137 & $1.34 \mathrm{E}+00$ & $2.99 \mathrm{E}-01$ & $\mathrm{~N} / \mathrm{A}$ & $1.06 \mathrm{E}-01$ & $1.74 \mathrm{E}+00$ & $1.74 \mathrm{E}+00$ \\
\hline $\mathrm{Ce}-144$ & 8.69E-02 & $4.55 \mathrm{E}-03$ & N/A & $5.92 \mathrm{E}-03$ & $9.74 \mathrm{E}-02$ & 8.69E-02 \\
\hline Eu-154 & 4.69E-02 & $3.39 \mathrm{E}-03$ & $\mathrm{~N} / \mathrm{A}$ & $1.56 \mathrm{E}-01$ & $2.06 \mathrm{E}-01$ & $0.00 \mathrm{E}+00$ \\
\hline Sr-90 & $4.04 \mathrm{E}-03$ & $\mathrm{a}$ & $\mathrm{N} / \mathrm{A}$ & 8.61E-03 & $1.27 \mathrm{E}-02$ & $1.27 \mathrm{E}-02$ \\
\hline
\end{tabular}


Table 13. Inventories in capsule rings, total hardware (Total of measured + MDA from Table 12), and total inventory measured outside of the fuel ("Grand Total measured + MDA" and "Grand Total measured only"). Errors are given based on propagation of uncertainty across the sum of all measured values. Shaded cells are based entirely on MDAs or cases where MDAs account for $>50 \%$ of a sum of MDAs and measured values.

\begin{tabular}{|c|c|c|c|c|c|c|c|c|}
\hline Capsule 5 & $\begin{array}{c}\text { Inner } \\
\text { Ring }\end{array}$ & $\begin{array}{c}\text { Outer } \\
\text { Ring }\end{array}$ & $\begin{array}{l}\text { Sink } \\
\text { Ring }\end{array}$ & $\begin{array}{c}\text { Hardware } \\
\text { (measured } \\
+ \text { MDA) }\end{array}$ & $\begin{array}{c}\text { Grand } \\
\text { Total } \\
\text { (measured } \\
+ \text { MDA) }\end{array}$ & $\begin{array}{c}\begin{array}{c}\text { Grand } \\
\text { Total } \\
\text { (measured } \\
\text { only) }\end{array} \\
\end{array}$ & $\begin{array}{c}\text { Error } \\
(\% \text { minus }) \\
\end{array}$ & $\begin{array}{c}\text { Error } \\
\text { (\% plus) }\end{array}$ \\
\hline $\begin{array}{c}\text { Ring } \\
\text { Material }\end{array}$ & Matrix & PCEA & PCEA & N/A & N/A & N/A & N/A & N/A \\
\hline $\begin{array}{c}\text { TAVA } \\
\text { Temp }\left({ }^{\circ} \mathrm{C}\right)\end{array}$ & 800 & 677 & 546 & N/A & N/A & N/A & N/A & N/A \\
\hline \multicolumn{9}{|c|}{ Decay-Corrected Activity (Bq) } \\
\hline $\mathrm{Ag}-110 \mathrm{~m}$ & $3.48 \mathrm{E}+05$ & $1.92 \mathrm{E}+05$ & $1.15 \mathrm{E}+06$ & $1.13 \mathrm{E}+06$ & $2.83 \mathrm{E}+06$ & $2.05 \mathrm{E}+06$ & $9.8 \%$ & $238.8 \%$ \\
\hline Cs-134 & $3.07 \mathrm{E}+08$ & $2.87 \mathrm{E}+06$ & $1.71 \mathrm{E}+07$ & $7.24 \mathrm{E}+06$ & $3.35 \mathrm{E}+08$ & $3.35 \mathrm{E}+08$ & $0.4 \%$ & $0.4 \%$ \\
\hline Cs-137 & $2.16 \mathrm{E}+08$ & $3.38 \mathrm{E}+06$ & $1.29 \mathrm{E}+07$ & $6.87 \mathrm{E}+06$ & $2.39 \mathrm{E}+08$ & $2.39 \mathrm{E}+08$ & $0.4 \%$ & $0.5 \%$ \\
\hline $\mathrm{Ce}-144$ & $\mathrm{~N} / \mathrm{D}$ & $\mathrm{N} / \mathrm{D}$ & $5.22 \mathrm{E}+06$ & $5.70 \mathrm{E}+06$ & $1.09 \mathrm{E}+07$ & $5.09 \mathrm{E}+06$ & $17.8 \%$ & $17.8 \%$ \\
\hline Eu-154 & $1.03 \mathrm{E}+06$ & $9.51 \mathrm{E}+05$ & $6.76 \mathrm{E}+04$ & $3.38 \mathrm{E}+04$ & $2.08 \mathrm{E}+06$ & 0 & - & - \\
\hline Sr-90 & a & $\mathrm{a}$ & $7.56 \mathrm{E}+04$ & $4.26 \mathrm{E}+04$ & $1.18 \mathrm{E}+05$ & $1.18 \mathrm{E}+05$ & $1.6 \%$ & $1.6 \%$ \\
\hline \multicolumn{9}{|c|}{ Capsule Fraction } \\
\hline $\mathrm{Ag}-110 \mathrm{~m}$ & $7.51 \mathrm{E}-04$ & 4.18E-04 & $2.50 \mathrm{E}-03$ & $2.45 \mathrm{E}-03$ & $6.12 \mathrm{E}-03$ & 4.44E-03 & $9.8 \%$ & $238.8 \%$ \\
\hline Cs-134 & $7.70 \mathrm{E}-03$ & $7.20 \mathrm{E}-05$ & $4.28 \mathrm{E}-04$ & $1.81 \mathrm{E}-04$ & $8.38 \mathrm{E}-03$ & $8.38 \mathrm{E}-03$ & $0.4 \%$ & $0.4 \%$ \\
\hline Cs-137 & 7.22E-03 & $1.13 \mathrm{E}-04$ & 4.33E-04 & $2.30 \mathrm{E}-04$ & $8.00 \mathrm{E}-03$ & $8.00 \mathrm{E}-03$ & $0.4 \%$ & $0.5 \%$ \\
\hline $\mathrm{Ce}-144$ & $\mathrm{~N} / \mathrm{D}$ & $\mathrm{N} / \mathrm{D}$ & $1.18 \mathrm{E}-05$ & $1.29 \mathrm{E}-05$ & $2.46 \mathrm{E}-05$ & $1.15 \mathrm{E}-05$ & $17.8 \%$ & $17.8 \%$ \\
\hline Eu-154 & $8.32 \mathrm{E}-04$ & 7.67E-04 & $5.45 \mathrm{E}-05$ & $2.72 \mathrm{E}-05$ & $1.68 \mathrm{E}-03$ & 0 & - & - \\
\hline Sr-90 & a & a & $2.97 \mathrm{E}-06$ & $1.67 \mathrm{E}-06$ & 4.64E-06 & 4.64E-06 & $1.6 \%$ & $1.6 \%$ \\
\hline \multicolumn{9}{|c|}{ Particle Equivalents } \\
\hline Ag-110m & $5.68 \mathrm{E}+00$ & $3.16 \mathrm{E}+00$ & $1.89 \mathrm{E}+01$ & $1.85 \mathrm{E}+01$ & $4.63 \mathrm{E}+01$ & $3.36 \mathrm{E}+01$ & $9.8 \%$ & $238.8 \%$ \\
\hline Cs-134 & $5.83 \mathrm{E}+01$ & $5.45 \mathrm{E}-01$ & $3.24 \mathrm{E}+00$ & $1.37 \mathrm{E}+00$ & $6.34 \mathrm{E}+01$ & $6.34 \mathrm{E}+01$ & $0.4 \%$ & $0.4 \%$ \\
\hline Cs-137 & $5.46 \mathrm{E}+01$ & $8.55 \mathrm{E}-01$ & $3.27 \mathrm{E}+00$ & $1.74 \mathrm{E}+00$ & $6.05 \mathrm{E}+01$ & $6.05 \mathrm{E}+01$ & $0.4 \%$ & $0.5 \%$ \\
\hline $\mathrm{Ce}-144$ & $\mathrm{~N} / \mathrm{D}$ & $\mathrm{N} / \mathrm{D}$ & 8.91E-02 & $9.74 \mathrm{E}-02$ & $1.86 \mathrm{E}-01$ & 8.69E-02 & $17.8 \%$ & $17.8 \%$ \\
\hline Eu-154 & $6.30 \mathrm{E}+00$ & $5.80 \mathrm{E}+00$ & 4.12E-01 & $2.06 \mathrm{E}-01$ & $1.27 \mathrm{E}+01$ & 0 & - & - \\
\hline Sr-90 & a & $\mathrm{a}$ & $2.24 \mathrm{E}-02$ & $1.27 \mathrm{E}-02$ & $3.51 \mathrm{E}-02$ & $3.51 \mathrm{E}-02$ & $1.6 \%$ & $1.6 \%$ \\
\hline \multicolumn{9}{|c|}{$\begin{array}{l}\text { N/A not applicable } \\
\text { N/D not detected on PGS, no MDAs determined } \\
\text { a. requires destructive analysis to measure }\end{array}$} \\
\hline
\end{tabular}




\subsection{Capsule 6}

Capsule 6 was a fuel body capsule, and this fuel body was not disassembled; therefore, neither the compacts nor the inner and outer rings could be scanned via PGS. Table 14 shows the activities, capsule fractions, and particle equivalents for selected isotopes measured on the capsule hardware. Table 15 represents the available (incomplete) mass balance for Capsule 6 (sink ring, foils, felts, spacers, and through tubes).

Table 14. Summary of inventories of select isotopes on Capsule 6 hardware. Shaded cells are based entirely on MDAs or cases where MDAs account for $>50 \%$ of a sum of MDAs and measured values.

\begin{tabular}{|c|c|c|c|c|c|c|}
\hline Capsule 6 & Foils & Felts $^{\mathbf{a}}$ & Spacers & $\begin{array}{c}\text { Through } \\
\text { Tubes } \\
\end{array}$ & $\begin{array}{c}\text { Total } \\
\text { (measured } \\
+ \text { MDA) } \\
\end{array}$ & $\begin{array}{c}\text { Total } \\
\text { (measured } \\
\text { only) } \\
\end{array}$ \\
\hline \multicolumn{7}{|c|}{ Decay-Corrected Activity (Bq) } \\
\hline Ag-110m & $1.16 \mathrm{E}+05$ & $2.92 \mathrm{E}+04$ & $8.64 \mathrm{E}+05$ & $8.46 \mathrm{E}+05$ & $1.86 \mathrm{E}+06$ & $8.75 \mathrm{E}+05$ \\
\hline Cs-134 & $4.05 \mathrm{E}+06$ & $8.32 \mathrm{E}+05$ & $5.69 \mathrm{E}+04$ & $9.73 \mathrm{E}+05$ & $5.92 \mathrm{E}+06$ & $5.86 \mathrm{E}+06$ \\
\hline Cs-137 & $4.65 \mathrm{E}+06$ & $5.39 \mathrm{E}+05$ & $4.30 \mathrm{E}+04$ & $7.36 \mathrm{E}+05$ & $5.96 \mathrm{E}+06$ & $5.96 \mathrm{E}+06$ \\
\hline $\mathrm{Ce}-144$ & $7.11 \mathrm{E}+05$ & $2.44 \mathrm{E}+05$ & $5.23 \mathrm{E}+06$ & $3.90 \mathrm{E}+05$ & $6.58 \mathrm{E}+06$ & $2.44 \mathrm{E}+05$ \\
\hline Eu-154 & $7.67 \mathrm{E}+03$ & $3.97 \mathrm{E}+02$ & $2.56 \mathrm{E}+04$ & $2.13 \mathrm{E}+04$ & $5.49 \mathrm{E}+04$ & $3.97 \mathrm{E}+02$ \\
\hline Sr-90 & $1.36 \mathrm{E}+04$ & $\mathrm{~b}$ & $2.13 \mathrm{E}+03$ & $9.87 \mathrm{E}+03$ & $2.56 \mathrm{E}+04$ & $2.56 \mathrm{E}+04$ \\
\hline \multicolumn{7}{|c|}{ Capsule Fraction } \\
\hline Ag-110m & $2.34 \mathrm{E}-04$ & $5.89 \mathrm{E}-05$ & $1.74 \mathrm{E}-03$ & $1.70 \mathrm{E}-03$ & $3.74 \mathrm{E}-03$ & $1.76 \mathrm{E}-03$ \\
\hline Cs-134 & $9.61 \mathrm{E}-05$ & $1.97 \mathrm{E}-05$ & $1.35 \mathrm{E}-06$ & $2.31 \mathrm{E}-05$ & $1.40 \mathrm{E}-04$ & $1.39 \mathrm{E}-04$ \\
\hline Cs-137 & $1.52 \mathrm{E}-04$ & $1.76 \mathrm{E}-05$ & $1.40 \mathrm{E}-06$ & $2.40 \mathrm{E}-05$ & $1.95 \mathrm{E}-04$ & $1.95 \mathrm{E}-04$ \\
\hline $\mathrm{Ce}-144$ & $1.57 \mathrm{E}-06$ & 5.39E-07 & $1.16 \mathrm{E}-05$ & $8.62 \mathrm{E}-07$ & $1.45 \mathrm{E}-05$ & 5.39E-07 \\
\hline Eu-154 & $5.95 \mathrm{E}-06$ & $3.08 \mathrm{E}-07$ & $1.98 \mathrm{E}-05$ & $1.65 \mathrm{E}-05$ & 4.26E-05 & $3.08 \mathrm{E}-07$ \\
\hline Sr-90 & $5.22 \mathrm{E}-07$ & $\mathrm{~b}$ & $8.17 \mathrm{E}-08$ & $3.78 \mathrm{E}-07$ & $9.82 \mathrm{E}-07$ & $9.82 \mathrm{E}-07$ \\
\hline \multicolumn{7}{|c|}{ Particle Equivalents } \\
\hline Ag-110m & $1.77 \mathrm{E}+00$ & $4.46 \mathrm{E}-01$ & $1.32 \mathrm{E}+01$ & $1.29 \mathrm{E}+01$ & $2.83 \mathrm{E}+01$ & $1.33 \mathrm{E}+01$ \\
\hline Cs-134 & $7.28 \mathrm{E}-01$ & $1.49 \mathrm{E}-01$ & $1.02 \mathrm{E}-02$ & $1.75 \mathrm{E}-01$ & $1.06 \mathrm{E}+00$ & $1.05 \mathrm{E}+00$ \\
\hline Cs-137 & $1.15 \mathrm{E}+00$ & $1.33 \mathrm{E}-01$ & $1.06 \mathrm{E}-02$ & $1.82 \mathrm{E}-01$ & $1.47 \mathrm{E}+00$ & $1.47 \mathrm{E}+00$ \\
\hline $\mathrm{Ce}-144$ & $1.19 \mathrm{E}-02$ & $4.08 \mathrm{E}-03$ & $8.74 \mathrm{E}-02$ & $6.52 \mathrm{E}-03$ & $1.10 \mathrm{E}-01$ & $4.08 \mathrm{E}-03$ \\
\hline $\mathrm{Eu}-154$ & 4.50E-02 & $2.33 \mathrm{E}-03$ & $1.50 \mathrm{E}-01$ & $1.25 \mathrm{E}-01$ & $3.22 \mathrm{E}-01$ & $2.33 \mathrm{E}-03$ \\
\hline Sr-90 & $3.95 \mathrm{E}-03$ & b & $6.18 \mathrm{E}-04$ & $2.86 \mathrm{E}-03$ & $7.43 \mathrm{E}-03$ & $7.43 \mathrm{E}-03$ \\
\hline
\end{tabular}


Table 15. Inventories in sink ring, total hardware (Total of measured + MDA from Table 14), and available inventory measured outside of the fuel ("Grand Total measured + MDA" and "Grand Total measured only"). Inner and outer rings not measured because Capsule 6 is an intact fuel body. Errors are given based on propagation of uncertainty across the sum of all measured values. Shaded cells are based entirely on MDAs or cases where MDAs account for $>50 \%$ of a sum of MDAs and measured values.

\begin{tabular}{|c|c|c|c|c|c|c|c|c|}
\hline Capsule 6 & $\begin{array}{c}\text { Inner } \\
\text { Ring }\end{array}$ & $\begin{array}{c}\text { Outer } \\
\text { Ring }\end{array}$ & $\begin{array}{l}\text { Sink } \\
\text { Ring }\end{array}$ & $\begin{array}{c}\text { Hardware } \\
\text { (measured } \\
+ \text { MDA) }\end{array}$ & $\begin{array}{c}\text { Grand } \\
\text { Total } \\
\text { (measured } \\
+ \text { MDA) }\end{array}$ & $\begin{array}{c}\begin{array}{c}\text { Grand } \\
\text { Total } \\
\text { (measured } \\
\text { only) }\end{array} \\
\end{array}$ & $\begin{array}{c}\text { Error } \\
\text { (\% minus) } \\
\end{array}$ & $\begin{array}{c}\text { Error } \\
\text { (\% plus) }\end{array}$ \\
\hline $\begin{array}{c}\text { Ring } \\
\text { Material }\end{array}$ & Matrix & PCEA & PCEA & N/A & $\mathrm{N} / \mathrm{A}$ & N/A & N/A & N/A \\
\hline $\begin{array}{c}\text { TAVA } \\
\text { Temp }\left({ }^{\circ} \mathrm{C}\right)\end{array}$ & 843 & 707 & 603 & $\mathrm{~N} / \mathrm{A}$ & $\mathrm{N} / \mathrm{A}$ & N/A & $\mathrm{N} / \mathrm{A}$ & N/A \\
\hline \multicolumn{9}{|c|}{ Decay-Corrected Activity (Bq) } \\
\hline $\mathrm{Ag}-110 \mathrm{~m}$ & $\mathrm{~N} / \mathrm{A}$ & $\mathrm{N} / \mathrm{A}$ & $4.20 \mathrm{E}+05$ & $1.86 \mathrm{E}+06$ & $2.28 \mathrm{E}+06$ & $8.46 \mathrm{E}+05$ & $4.0 \%$ & $4.0 \%$ \\
\hline Cs-134 & $\mathrm{N} / \mathrm{A}$ & $\mathrm{N} / \mathrm{A}$ & $1.24 \mathrm{E}+07$ & $5.92 \mathrm{E}+06$ & $1.83 \mathrm{E}+07$ & $1.83 \mathrm{E}+07$ & $3.7 \%$ & $3.7 \%$ \\
\hline Cs-137 & $\mathrm{N} / \mathrm{A}$ & $\mathrm{N} / \mathrm{A}$ & $1.32 \mathrm{E}+07$ & $5.96 \mathrm{E}+06$ & $1.92 \mathrm{E}+07$ & $1.92 \mathrm{E}+07$ & $3.7 \%$ & $3.7 \%$ \\
\hline $\mathrm{Ce}-144$ & $\mathrm{~N} / \mathrm{A}$ & $\mathrm{N} / \mathrm{A}$ & $5.11 \mathrm{E}+06$ & $6.58 \mathrm{E}+06$ & $1.17 \mathrm{E}+07$ & $0.00 \mathrm{E}+00$ & - & - \\
\hline Eu-154 & $\mathrm{N} / \mathrm{A}$ & $\mathrm{N} / \mathrm{A}$ & $5.54 \mathrm{E}+04$ & $5.49 \mathrm{E}+04$ & $1.10 \mathrm{E}+05$ & $3.97 \mathrm{E}+02$ & $27.6 \%$ & $27.6 \%$ \\
\hline Sr-90 & a & a & $6.28 \mathrm{E}+04$ & $2.56 \mathrm{E}+04$ & $8.84 \mathrm{E}+04$ & $8.84 \mathrm{E}+04$ & $3.0 \%$ & $3.0 \%$ \\
\hline \multicolumn{9}{|c|}{ Capsule Fraction } \\
\hline $\mathrm{Ag}-110 \mathrm{~m}$ & N/A & N/A & $8.47 \mathrm{E}-04$ & $3.74 \mathrm{E}-03$ & $4.58 \mathrm{E}-03$ & $1.70 \mathrm{E}-03$ & $4.0 \%$ & $4.0 \%$ \\
\hline Cs-134 & N/A & N/A & $2.94 \mathrm{E}-04$ & $1.40 \mathrm{E}-04$ & $4.34 \mathrm{E}-04$ & 4.33E-04 & $3.7 \%$ & $3.7 \%$ \\
\hline Cs-137 & $\mathrm{N} / \mathrm{A}$ & N/A & 4.32E-04 & $1.95 \mathrm{E}-04$ & $6.27 \mathrm{E}-04$ & $6.27 \mathrm{E}-04$ & $3.7 \%$ & $3.7 \%$ \\
\hline $\mathrm{Ce}-144$ & $\mathrm{~N} / \mathrm{A}$ & $\mathrm{N} / \mathrm{A}$ & $1.13 \mathrm{E}-05$ & $1.45 \mathrm{E}-05$ & $2.58 \mathrm{E}-05$ & $0.00 \mathrm{E}+00$ & - & - \\
\hline Eu-154 & $\mathrm{N} / \mathrm{A}$ & $\mathrm{N} / \mathrm{A}$ & $4.30 \mathrm{E}-05$ & $4.26 \mathrm{E}-05$ & $8.55 \mathrm{E}-05$ & $3.08 \mathrm{E}-07$ & $27.6 \%$ & $27.6 \%$ \\
\hline Sr-90 & a & a & $2.41 \mathrm{E}-06$ & $9.82 \mathrm{E}-07$ & $3.39 \mathrm{E}-06$ & $3.39 \mathrm{E}-06$ & $3.0 \%$ & $3.0 \%$ \\
\hline \multicolumn{9}{|c|}{ Particle Equivalents } \\
\hline $\mathrm{Ag}-110 \mathrm{~m}$ & $\mathrm{~N} / \mathrm{A}$ & $\mathrm{N} / \mathrm{A}$ & $6.41 \mathrm{E}+00$ & $2.83 \mathrm{E}+01$ & $3.47 \mathrm{E}+01$ & $1.29 \mathrm{E}+01$ & $4.0 \%$ & $4.0 \%$ \\
\hline Cs-134 & $\mathrm{N} / \mathrm{A}$ & $\mathrm{N} / \mathrm{A}$ & $2.23 \mathrm{E}+00$ & $1.06 \mathrm{E}+00$ & $3.29 \mathrm{E}+00$ & $3.28 \mathrm{E}+00$ & $3.7 \%$ & $3.7 \%$ \\
\hline Cs-137 & N/A & N/A & $3.27 \mathrm{E}+00$ & $1.47 \mathrm{E}+00$ & $4.74 \mathrm{E}+00$ & $4.74 \mathrm{E}+00$ & $3.7 \%$ & $3.7 \%$ \\
\hline $\mathrm{Ce}-144$ & N/A & N/A & 8.54E-02 & $1.10 \mathrm{E}-01$ & $1.95 \mathrm{E}-01$ & $0.00 \mathrm{E}+00$ & - & - \\
\hline $\mathrm{Eu}-154$ & N/A & N/A & $3.25 \mathrm{E}-01$ & $3.22 \mathrm{E}-01$ & $6.47 \mathrm{E}-01$ & $2.33 \mathrm{E}-03$ & $27.6 \%$ & $27.6 \%$ \\
\hline Sr-90 & $\mathrm{a}$ & $\mathrm{a}$ & $1.82 \mathrm{E}-02$ & $7.43 \mathrm{E}-03$ & $2.57 \mathrm{E}-02$ & $2.57 \mathrm{E}-02$ & $3.0 \%$ & $3.0 \%$ \\
\hline
\end{tabular}




\subsection{Capsule 7}

Capsule 7 was a standard-type capsule and was the hottest capsule in the irradiation. Table 16 shows the activities, capsule fractions, and particle equivalents for selected isotopes measured on the capsule hardware. Note that only one spacer was recovered from Capsule 7, and due to the radioactivity on the felts, they had to be sent to AL for gamma counting. The screws and a few small pieces of graphite debris (all originally packaged with the felts) were separated from the felts and counted on the HOGS. The "Felts" column in Table 16 is the sum of the counts of the felts, screws, and graphite debris. Table 17 represents the entire mass balance for Capsule 7 (inner ring, outer ring, sink ring, foils, felts, spacers, and through tubes).

Table 16. Summary of inventories of select isotopes on Capsule 7 hardware. Shaded cells are based entirely on MDAs or cases where MDAs account for $>50 \%$ of a sum of MDAs and measured values.

\begin{tabular}{|c|c|c|c|c|c|c|}
\hline Capsule 7 & Foils & Felts $^{\mathbf{a}}$ & Spacers & $\begin{array}{c}\text { Through } \\
\text { Tubes } \\
\end{array}$ & $\begin{array}{c}\text { Total } \\
\text { (measured } \\
+ \text { MDA) } \\
\end{array}$ & $\begin{array}{c}\text { Total } \\
\text { (measured } \\
\text { only) }\end{array}$ \\
\hline \multicolumn{7}{|c|}{ Decay-Corrected Activity (Bq) } \\
\hline Ag-110m & $2.26 \mathrm{E}+05$ & $2.09 \mathrm{E}+06$ & $4.09 \mathrm{E}+04$ & $1.05 \mathrm{E}+06$ & $3.41 \mathrm{E}+06$ & $3.15 \mathrm{E}+06$ \\
\hline Cs-134 & $8.94 \mathrm{E}+05$ & $2.83 \mathrm{E}+07$ & $1.10 \mathrm{E}+06$ & $2.30 \mathrm{E}+06$ & $3.25 \mathrm{E}+07$ & $3.25 \mathrm{E}+07$ \\
\hline Cs-137 & $5.12 \mathrm{E}+06$ & $2.06 \mathrm{E}+07$ & $8.27 \mathrm{E}+05$ & $2.32 \mathrm{E}+06$ & $2.88 \mathrm{E}+07$ & $2.88 \mathrm{E}+07$ \\
\hline $\mathrm{Ce}-144$ & $1.33 \mathrm{E}+06$ & $1.00 \mathrm{E}+06$ & $1.25 \mathrm{E}+05$ & $3.90 \mathrm{E}+05$ & $2.91 \mathrm{E}+06$ & 0 \\
\hline Eu-154 & $3.97 \mathrm{E}+05$ & $3.99 \mathrm{E}+04$ & $2.11 \mathrm{E}+05$ & $2.87 \mathrm{E}+04$ & $6.77 \mathrm{E}+05$ & $6.48 \mathrm{E}+05$ \\
\hline Sr-90 & $1.11 \mathrm{E}+07$ & $\mathrm{~b}$ & $4.18 \mathrm{E}+04$ & $3.83 \mathrm{E}+04$ & $1.12 \mathrm{E}+07$ & $8.41 \mathrm{E}+05$ \\
\hline \multicolumn{7}{|c|}{ Capsule Fraction } \\
\hline Ag-110m & 4.79E-04 & $4.45 \mathrm{E}-03$ & $8.68 \mathrm{E}-05$ & $2.24 \mathrm{E}-03$ & 7.25E-03 & $6.68 \mathrm{E}-03$ \\
\hline Cs-134 & 2.22E-05 & 7.04E-04 & $2.73 \mathrm{E}-05$ & $5.72 \mathrm{E}-05$ & $8.10 \mathrm{E}-04$ & $8.10 \mathrm{E}-04$ \\
\hline Cs-137 & $1.70 \mathrm{E}-04$ & $6.84 \mathrm{E}-04$ & $2.75 \mathrm{E}-05$ & 7.72E-05 & $9.59 \mathrm{E}-04$ & $9.59 \mathrm{E}-04$ \\
\hline $\mathrm{Ce}-144$ & $2.98 \mathrm{E}-06$ & $2.38 \mathrm{E}-06$ & $2.79 \mathrm{E}-07$ & $8.75 \mathrm{E}-07$ & $6.52 \mathrm{E}-06$ & 0 \\
\hline Eu-154 & $3.22 \mathrm{E}-04$ & $3.23 \mathrm{E}-05$ & $1.71 \mathrm{E}-04$ & $2.33 \mathrm{E}-05$ & $5.48 \mathrm{E}-04$ & $5.25 \mathrm{E}-04$ \\
\hline Sr-90 & 4.32E-04 & $\mathrm{b}$ & $1.63 \mathrm{E}-06$ & $1.49 \mathrm{E}-06$ & 4.35E-04 & 4.35E-04 \\
\hline \multicolumn{7}{|c|}{ Particle Equivalents } \\
\hline Ag-110m & $3.63 \mathrm{E}+00$ & $3.37 \mathrm{E}+01$ & $6.57 \mathrm{E}-01$ & $1.69 \mathrm{E}+01$ & $5.49 \mathrm{E}+01$ & $5.06 \mathrm{E}+01$ \\
\hline Cs-134 & $1.68 \mathrm{E}-01$ & $5.32 \mathrm{E}+00$ & $2.07 \mathrm{E}-01$ & 4.33E-01 & $6.13 \mathrm{E}+00$ & $6.13 \mathrm{E}+00$ \\
\hline Cs-137 & $1.29 \mathrm{E}+00$ & $5.18 \mathrm{E}+00$ & $2.08 \mathrm{E}-01$ & $5.84 \mathrm{E}-01$ & $7.26 \mathrm{E}+00$ & $7.26 \mathrm{E}+00$ \\
\hline $\mathrm{Ce}-144$ & $2.26 \mathrm{E}-02$ & $1.80 \mathrm{E}-02$ & $2.11 \mathrm{E}-03$ & $6.62 \mathrm{E}-03$ & $4.93 \mathrm{E}-02$ & 0 \\
\hline $\mathrm{Eu}-154$ & $2.43 \mathrm{E}+00$ & $2.45 \mathrm{E}-01$ & $1.29 \mathrm{E}+00$ & $1.76 \mathrm{E}-01$ & $4.15 \mathrm{E}+00$ & $3.97 \mathrm{E}+00$ \\
\hline Sr-90 & $3.27 \mathrm{E}+00$ & $\mathrm{~b}$ & $1.23 \mathrm{E}-02$ & $1.13 \mathrm{E}-02$ & $3.29 \mathrm{E}+00$ & $3.29 \mathrm{E}+00$ \\
\hline
\end{tabular}


Table 17. Inventories in capsule rings, total hardware (Total of measured + MDA from Table 16), and total inventory measured outside of the fuel ("Grand Total measured + MDA" and "Grand Total measured only"). Errors are given based on propagation of uncertainty across the sum of all measured values. Shaded cells are based entirely on MDAs or cases where MDAs account for $>50 \%$ of a sum of MDAs and measured values.

\begin{tabular}{|c|c|c|c|c|c|c|c|c|}
\hline Capsule 7 & $\begin{array}{c}\text { Inner } \\
\text { Ring }\end{array}$ & $\begin{array}{c}\text { Outer } \\
\text { Ring }\end{array}$ & $\begin{array}{l}\text { Sink } \\
\text { Ring }\end{array}$ & $\begin{array}{c}\text { Hardware } \\
\text { (measured } \\
+ \text { MDA) } \\
\end{array}$ & $\begin{array}{c}\text { Grand } \\
\text { Total } \\
\text { (measured } \\
+ \text { MDA) }\end{array}$ & $\begin{array}{c}\text { Grand } \\
\text { Total } \\
\text { (measured } \\
\text { only) }\end{array}$ & $\begin{array}{c}\text { Error } \\
(\% \text { minus }) \\
\end{array}$ & $\begin{array}{c}\text { Error } \\
\text { (\% plus) }\end{array}$ \\
\hline $\begin{array}{c}\text { Ring } \\
\text { Material }\end{array}$ & Matrix & PCEA & PCEA & N/A & N/A & N/A & $\mathrm{N} / \mathrm{A}$ & N/A \\
\hline $\begin{array}{c}\text { TAVA } \\
\text { Temp }\left({ }^{\circ} \mathrm{C}\right)\end{array}$ & 1151 & 1025 & 617 & N/A & N/A & N/A & $\mathrm{N} / \mathrm{A}$ & N/A \\
\hline \multicolumn{9}{|c|}{ Decay-Corrected Activity (Bq) } \\
\hline $\mathrm{Ag}-110 \mathrm{~m}$ & $1.33 \mathrm{E}+05$ & $9.66 \mathrm{E}+06$ & $4.63 \mathrm{E}+08$ & $3.41 \mathrm{E}+06$ & $4.76 \mathrm{E}+08$ & $4.76 \mathrm{E}+08$ & $4.8 \%$ & $4.8 \%$ \\
\hline Cs-134 & $2.49 \mathrm{E}+07$ & $3.90 \mathrm{E}+07$ & $1.44 \mathrm{E}+08$ & $3.25 \mathrm{E}+07$ & $2.40 \mathrm{E}+08$ & $2.40 \mathrm{E}+08$ & $3.1 \%$ & $3.1 \%$ \\
\hline Cs-137 & $2.18 \mathrm{E}+07$ & $3.22 \mathrm{E}+07$ & $1.14 \mathrm{E}+08$ & $2.88 \mathrm{E}+07$ & $1.97 \mathrm{E}+08$ & $1.97 \mathrm{E}+08$ & $3.0 \%$ & $3.0 \%$ \\
\hline $\mathrm{Ce}-144$ & $\mathrm{~N} / \mathrm{D}$ & $\mathrm{N} / \mathrm{D}$ & $3.57 \mathrm{E}+06$ & $2.91 \mathrm{E}+06$ & $6.48 \mathrm{E}+06$ & $0.00 \mathrm{E}+00$ & - & - \\
\hline Eu-154 & $3.74 \mathrm{E}+07$ & $9.44 \mathrm{E}+05$ & $7.40 \mathrm{E}+04$ & $6.77 \mathrm{E}+05$ & $3.91 \mathrm{E}+07$ & $3.81 \mathrm{E}+07$ & $1.1 \%$ & $1.4 \%$ \\
\hline Sr-90 & a & a & $1.36 \mathrm{E}+05$ & $1.12 \mathrm{E}+07$ & $1.13 \mathrm{E}+07$ & $1.13 \mathrm{E}+07$ & $1.1 \%$ & $1.1 \%$ \\
\hline \multicolumn{9}{|c|}{ Capsule Fraction } \\
\hline $\mathrm{Ag}-110 \mathrm{~m}$ & $2.83 \mathrm{E}-04$ & $2.05 \mathrm{E}-02$ & $9.83 \mathrm{E}-01$ & $7.25 \mathrm{E}-03$ & $1.01 \mathrm{E}+00$ & $1.01 \mathrm{E}+00$ & $4.8 \%$ & $4.8 \%$ \\
\hline Cs-134 & $6.19 \mathrm{E}-04$ & $9.71 \mathrm{E}-04$ & $3.58 \mathrm{E}-03$ & $8.10 \mathrm{E}-04$ & $5.98 \mathrm{E}-03$ & $5.98 \mathrm{E}-03$ & $3.1 \%$ & $3.1 \%$ \\
\hline Cs-137 & $7.26 \mathrm{E}-04$ & $1.07 \mathrm{E}-03$ & $3.80 \mathrm{E}-03$ & $9.59 \mathrm{E}-04$ & $6.56 \mathrm{E}-03$ & $6.56 \mathrm{E}-03$ & $3.0 \%$ & $3.0 \%$ \\
\hline $\mathrm{Ce}-144$ & $\mathrm{~N} / \mathrm{D}$ & $\mathrm{N} / \mathrm{D}$ & $8.00 \mathrm{E}-06$ & $6.52 \mathrm{E}-06$ & $1.45 \mathrm{E}-05$ & $0.00 \mathrm{E}+00$ & - & 一 \\
\hline Eu-154 & $3.03 \mathrm{E}-02$ & 7.63E-04 & $5.99 \mathrm{E}-05$ & $5.48 \mathrm{E}-04$ & $3.17 \mathrm{E}-02$ & $3.08 \mathrm{E}-02$ & $1.1 \%$ & $1.4 \%$ \\
\hline Sr-90 & a & a & 5.31E-06 & 4.35E-04 & $4.40 \mathrm{E}-04$ & 4.40E-04 & $1.1 \%$ & $1.1 \%$ \\
\hline \multicolumn{9}{|c|}{ Particle Equivalents } \\
\hline $\mathrm{Ag}-110 \mathrm{~m}$ & $2.14 \mathrm{E}+00$ & $1.55 \mathrm{E}+02$ & $7.44 \mathrm{E}+03$ & $5.49 \mathrm{E}+01$ & $7.65 \mathrm{E}+03$ & $7.65 \mathrm{E}+03$ & $4.8 \%$ & $4.8 \%$ \\
\hline Cs-134 & $4.68 \mathrm{E}+00$ & $7.35 \mathrm{E}+00$ & $2.71 \mathrm{E}+01$ & $6.13 \mathrm{E}+00$ & $4.52 \mathrm{E}+01$ & $4.52 \mathrm{E}+01$ & $3.1 \%$ & $3.1 \%$ \\
\hline Cs-137 & $5.49 \mathrm{E}+00$ & $8.10 \mathrm{E}+00$ & $2.88 \mathrm{E}+01$ & $7.26 \mathrm{E}+00$ & $4.96 \mathrm{E}+01$ & $4.96 \mathrm{E}+01$ & $3.0 \%$ & $3.0 \%$ \\
\hline $\mathrm{Ce}-144$ & N/D & $\mathrm{N} / \mathrm{D}$ & $6.06 \mathrm{E}-02$ & 4.93E-02 & $1.10 \mathrm{E}-01$ & $0.00 \mathrm{E}+00$ & - & - \\
\hline Eu-154 & $2.29 \mathrm{E}+02$ & $5.77 \mathrm{E}+00$ & $4.54 \mathrm{E}-01$ & $4.15 \mathrm{E}+00$ & $2.40 \mathrm{E}+02$ & $2.33 \mathrm{E}+02$ & $1.1 \%$ & $1.4 \%$ \\
\hline Sr-90 & $\mathrm{a}$ & a & $4.02 \mathrm{E}-02$ & $3.29 \mathrm{E}+00$ & $3.33 \mathrm{E}+00$ & $3.33 \mathrm{E}+00$ & $1.1 \%$ & $1.1 \%$ \\
\hline \multicolumn{9}{|c|}{$\begin{array}{ll}\text { N/A } & \text { not applicable. } \\
\text { N/D } & \text { not detected on PGS, no MDAs determined. } \\
\text { a. } & \text { requires destructive analysis to measure. }\end{array}$} \\
\hline
\end{tabular}




\subsection{Capsule 8}

Capsule 8 was a standard-type capsule, and Table 18 shows the activities, capsule fractions, and particle equivalents for selected isotopes measured on the capsule hardware. Table 19 represents the entire mass balance for Capsule 8 (inner ring, outer ring, sink ring, foils, felts, spacers, and through tubes).

Table 18. Summary of inventories of select isotopes on Capsule 8 hardware. Shaded cells are based entirely on MDAs or cases where MDAs account for $>50 \%$ of a sum of MDAs and measured values.

\begin{tabular}{|c|c|c|c|c|c|c|}
\hline Capsule 8 & Foils & Felts $^{\mathbf{a}}$ & Spacers & $\begin{array}{c}\text { Through } \\
\text { Tubes }\end{array}$ & $\begin{array}{c}\text { Total } \\
\text { (measured } \\
+ \text { MDA) } \\
\end{array}$ & $\begin{array}{c}\text { Total } \\
\text { (measured } \\
\text { only) }\end{array}$ \\
\hline \multicolumn{7}{|c|}{ Decay-Corrected Activity (Bq) } \\
\hline Ag-110m & $2.14 \mathrm{E}+05$ & $1.62 \mathrm{E}+06$ & $1.04 \mathrm{E}+05$ & $1.46 \mathrm{E}+06$ & $3.40 \mathrm{E}+06$ & $3.08 \mathrm{E}+06$ \\
\hline Cs-134 & $2.45 \mathrm{E}+06$ & $7.60 \mathrm{E}+06$ & $5.26 \mathrm{E}+05$ & $2.85 \mathrm{E}+06$ & $1.34 \mathrm{E}+07$ & $1.34 \mathrm{E}+07$ \\
\hline Cs-137 & $6.60 \mathrm{E}+06$ & $6.29 \mathrm{E}+06$ & $3.02 \mathrm{E}+05$ & $2.91 \mathrm{E}+06$ & $1.61 \mathrm{E}+07$ & $1.61 \mathrm{E}+07$ \\
\hline $\mathrm{Ce}-144$ & $1.33 \mathrm{E}+06$ & $5.18 \mathrm{E}+05$ & $9.72 \mathrm{E}+05$ & $3.47 \mathrm{E}+05$ & $3.17 \mathrm{E}+06$ & $9.72 \mathrm{E}+05$ \\
\hline Eu-154 & $6.85 \mathrm{E}+04$ & $8.50 \mathrm{E}+03$ & $7.61 \mathrm{E}+05$ & $2.55 \mathrm{E}+04$ & $8.63 \mathrm{E}+05$ & $7.69 \mathrm{E}+05$ \\
\hline Sr-90 & $2.04 \mathrm{E}+06$ & $\mathrm{~b}$ & $7.72 \mathrm{E}+03$ & $1.69 \mathrm{E}+04$ & $2.07 \mathrm{E}+06$ & $2.07 \mathrm{E}+06$ \\
\hline \multicolumn{7}{|c|}{ Capsule Fraction } \\
\hline Ag-110m & $5.03 \mathrm{E}-04$ & $3.81 \mathrm{E}-03$ & $2.44 \mathrm{E}-04$ & $3.43 \mathrm{E}-03$ & 7.99E-03 & $7.24 \mathrm{E}-03$ \\
\hline Cs-134 & $6.60 \mathrm{E}-05$ & $2.05 \mathrm{E}-04$ & $1.42 \mathrm{E}-05$ & $7.68 \mathrm{E}-05$ & $3.62 \mathrm{E}-04$ & $3.62 \mathrm{E}-04$ \\
\hline Cs-137 & $2.26 \mathrm{E}-04$ & $2.16 \mathrm{E}-04$ & $1.04 \mathrm{E}-05$ & 9.99E-05 & $5.52 \mathrm{E}-04$ & $5.52 \mathrm{E}-04$ \\
\hline Ce-144 & $3.07 \mathrm{E}-06$ & $1.19 \mathrm{E}-06$ & 2.24E-06 & 7.99E-07 & 7.30E-06 & 2.24E-06 \\
\hline Eu-154 & $5.87 \mathrm{E}-05$ & 7.29E-06 & $6.53 \mathrm{E}-04$ & 2.19E-05 & $7.40 \mathrm{E}-04$ & $6.60 \mathrm{E}-04$ \\
\hline Sr-90 & $8.15 \mathrm{E}-05$ & $\mathrm{~b}$ & $3.08 \mathrm{E}-07$ & $6.76 \mathrm{E}-07$ & $8.25 \mathrm{E}-05$ & $8.25 \mathrm{E}-05$ \\
\hline \multicolumn{7}{|c|}{ Particle Equivalents } \\
\hline Ag-110m & $3.81 \mathrm{E}+00$ & $2.88 \mathrm{E}+01$ & $1.84 \mathrm{E}+00$ & $2.59 \mathrm{E}+01$ & $6.04 \mathrm{E}+01$ & $5.48 \mathrm{E}+01$ \\
\hline Cs-134 & $5.00 \mathrm{E}-01$ & $1.55 \mathrm{E}+00$ & $1.07 \mathrm{E}-01$ & $5.81 \mathrm{E}-01$ & $2.74 \mathrm{E}+00$ & $2.74 \mathrm{E}+00$ \\
\hline Cs-137 & $1.71 \mathrm{E}+00$ & $1.63 \mathrm{E}+00$ & 7.84E-02 & $7.56 \mathrm{E}-01$ & $4.18 \mathrm{E}+00$ & $4.18 \mathrm{E}+00$ \\
\hline $\mathrm{Ce}-144$ & $2.32 \mathrm{E}-02$ & $9.02 \mathrm{E}-03$ & $1.69 \mathrm{E}-02$ & $6.05 \mathrm{E}-03$ & $5.52 \mathrm{E}-02$ & $1.69 \mathrm{E}-02$ \\
\hline $\mathrm{Eu}-154$ & 4.44E-01 & $5.52 \mathrm{E}-02$ & $4.94 \mathrm{E}+00$ & $1.66 \mathrm{E}-01$ & $5.60 \mathrm{E}+00$ & $4.99 \mathrm{E}+00$ \\
\hline Sr-90 & $6.17 \mathrm{E}-01$ & $\mathrm{~b}$ & $2.33 \mathrm{E}-03$ & $5.12 \mathrm{E}-03$ & $6.25 \mathrm{E}-01$ & $6.25 \mathrm{E}-01$ \\
\hline
\end{tabular}


Table 19. Inventories in capsule rings, total hardware (Total of measured + MDA from Table 18), and total inventory measured outside of the fuel ("Grand Total measured + MDA" and "Grand Total measured only"). Errors are given based on propagation of uncertainty across the sum of all measured values. Shaded cells are based entirely on MDAs or cases where MDAs account for $>50 \%$ of a sum of MDAs and measured values.

\begin{tabular}{|c|c|c|c|c|c|c|c|c|}
\hline Capsule 8 & $\begin{array}{c}\text { Inner } \\
\text { Ring }\end{array}$ & $\begin{array}{c}\text { Outer } \\
\text { Ring }\end{array}$ & $\begin{array}{l}\text { Sink } \\
\text { Ring } \\
\end{array}$ & $\begin{array}{c}\text { Hardware } \\
\text { (measured } \\
+ \text { MDA) } \\
\end{array}$ & $\begin{array}{c}\text { Grand } \\
\text { Total } \\
\text { (measured } \\
+ \text { MDA) }\end{array}$ & $\begin{array}{c}\text { Grand } \\
\text { Total } \\
\text { (measured } \\
\text { only) }\end{array}$ & $\begin{array}{c}\text { Error } \\
\text { (\% minus) }\end{array}$ & $\begin{array}{c}\text { Error } \\
\text { (\% plus) }\end{array}$ \\
\hline $\begin{array}{c}\text { Ring } \\
\text { Material }\end{array}$ & IG-110 & IG-110 & PCEA & N/A & N/A & $\mathrm{N} / \mathrm{A}$ & N/A & N/A \\
\hline $\begin{array}{c}\text { TAVA } \\
\text { Temp }\left({ }^{\circ} \mathrm{C}\right)\end{array}$ & 1021 & 917 & 582 & N/A & N/A & N/A & N/A & N/A \\
\hline \multicolumn{9}{|c|}{ Decay-Corrected Activity (Bq) } \\
\hline $\mathrm{Ag}-110 \mathrm{~m}$ & $3.27 \mathrm{E}+07$ & $3.00 \mathrm{E}+08$ & $3.99 \mathrm{E}+07$ & $3.40 \mathrm{E}+06$ & $3.76 \mathrm{E}+08$ & $3.76 \mathrm{E}+08$ & $0.8 \%$ & $1.0 \%$ \\
\hline Cs-134 & $2.66 \mathrm{E}+07$ & $1.25 \mathrm{E}+08$ & $9.22 \mathrm{E}+07$ & $1.34 \mathrm{E}+07$ & $2.57 \mathrm{E}+08$ & $2.57 \mathrm{E}+08$ & $2.2 \%$ & $2.2 \%$ \\
\hline Cs-137 & $2.70 \mathrm{E}+07$ & $1.08 \mathrm{E}+08$ & $8.02 \mathrm{E}+07$ & $1.61 \mathrm{E}+07$ & $2.32 \mathrm{E}+08$ & $2.32 \mathrm{E}+08$ & $2.0 \%$ & $2.0 \%$ \\
\hline $\mathrm{Ce}-144$ & $\mathrm{~N} / \mathrm{D}$ & $\mathrm{N} / \mathrm{D}$ & $4.42 \mathrm{E}+06$ & $3.17 \mathrm{E}+06$ & $7.58 \mathrm{E}+06$ & $9.72 \mathrm{E}+05$ & $15.6 \%$ & $15.6 \%$ \\
\hline Eu-154 & $9.36 \mathrm{E}+05$ & $1.11 \mathrm{E}+06$ & $4.07 \mathrm{E}+04$ & $8.63 \mathrm{E}+05$ & $2.95 \mathrm{E}+06$ & $1.71 \mathrm{E}+06$ & $7.1 \%$ & $66.7 \%$ \\
\hline Sr-90 & a & a & $2.79 \mathrm{E}+05$ & $2.07 \mathrm{E}+06$ & $2.34 \mathrm{E}+06$ & $2.34 \mathrm{E}+06$ & $1.0 \%$ & $1.0 \%$ \\
\hline \multicolumn{9}{|c|}{ Capsule Fraction } \\
\hline $\mathrm{Ag}-110 \mathrm{~m}$ & $7.68 \mathrm{E}-02$ & 7.04E-01 & $9.37 \mathrm{E}-02$ & $7.99 \mathrm{E}-03$ & $8.82 \mathrm{E}-01$ & $8.82 \mathrm{E}-01$ & $0.8 \%$ & $1.0 \%$ \\
\hline Cs-134 & $7.14 \mathrm{E}-04$ & $3.36 \mathrm{E}-03$ & $2.48 \mathrm{E}-03$ & $3.62 \mathrm{E}-04$ & $6.92 \mathrm{E}-03$ & $6.92 \mathrm{E}-03$ & $2.2 \%$ & $2.2 \%$ \\
\hline Cs-137 & $9.25 \mathrm{E}-04$ & $3.72 \mathrm{E}-03$ & $2.75 \mathrm{E}-03$ & $5.52 \mathrm{E}-04$ & $7.95 \mathrm{E}-03$ & 7.95E-03 & $2.0 \%$ & $2.0 \%$ \\
\hline $\mathrm{Ce}-144$ & $\mathrm{~N} / \mathrm{D}$ & $\mathrm{N} / \mathrm{D}$ & $1.02 \mathrm{E}-05$ & $7.30 \mathrm{E}-06$ & $1.75 \mathrm{E}-05$ & $2.24 \mathrm{E}-06$ & $15.6 \%$ & $15.6 \%$ \\
\hline Eu-154 & $8.02 \mathrm{E}-04$ & $9.55 \mathrm{E}-04$ & $3.49 \mathrm{E}-05$ & $7.40 \mathrm{E}-04$ & $2.53 \mathrm{E}-03$ & $1.46 \mathrm{E}-03$ & $7.1 \%$ & $66.7 \%$ \\
\hline Sr-90 & a & a & $1.11 \mathrm{E}-05$ & $8.25 \mathrm{E}-05$ & $9.37 \mathrm{E}-05$ & 9.37E-05 & $1.0 \%$ & $1.0 \%$ \\
\hline \multicolumn{9}{|c|}{ Particle Equivalents } \\
\hline $\mathrm{Ag}-110 \mathrm{~m}$ & $5.81 \mathrm{E}+02$ & $5.33 \mathrm{E}+03$ & $7.09 \mathrm{E}+02$ & $6.04 \mathrm{E}+01$ & $6.68 \mathrm{E}+03$ & $6.67 \mathrm{E}+03$ & $0.8 \%$ & $1.0 \%$ \\
\hline Cs-134 & $5.40 \mathrm{E}+00$ & $2.54 \mathrm{E}+01$ & $1.88 \mathrm{E}+01$ & $2.74 \mathrm{E}+00$ & $5.23 \mathrm{E}+01$ & $5.23 \mathrm{E}+01$ & $2.2 \%$ & $2.2 \%$ \\
\hline Cs-137 & $7.00 \mathrm{E}+00$ & $2.82 \mathrm{E}+01$ & $2.08 \mathrm{E}+01$ & $4.18 \mathrm{E}+00$ & $6.02 \mathrm{E}+01$ & $6.02 \mathrm{E}+01$ & $2.0 \%$ & $2.0 \%$ \\
\hline $\mathrm{Ce}-144$ & $\mathrm{~N} / \mathrm{D}$ & N/D & 7.69E-02 & $5.52 \mathrm{E}-02$ & $1.32 \mathrm{E}-01$ & 1.69E-02 & $15.6 \%$ & $15.6 \%$ \\
\hline Eu-154 & $6.07 \mathrm{E}+00$ & $7.23 \mathrm{E}+00$ & 2.64E-01 & $5.60 \mathrm{E}+00$ & $1.92 \mathrm{E}+01$ & $1.11 \mathrm{E}+01$ & $7.1 \%$ & $66.7 \%$ \\
\hline Sr-90 & $\mathrm{a}$ & a & $8.43 \mathrm{E}-02$ & $6.25 \mathrm{E}-01$ & $7.09 \mathrm{E}-01$ & 7.09E-01 & $1.0 \%$ & $1.0 \%$ \\
\hline \multicolumn{9}{|c|}{$\begin{array}{ll}\text { N/A } & \text { not applicable. } \\
\text { N/D } & \text { not detected on PGS, no MDAs determined. } \\
\text { a. } & \text { requires destructive analysis to measure. }\end{array}$} \\
\hline
\end{tabular}




\subsection{Capsule 9}

Capsule 9 was a fuel body capsule, and this fuel body was not disassembled; therefore, neither the compacts nor the inner and outer rings could be scanned via PGS. Without the inner and outer rings, the inventory outside of the fuel compacts is incomplete. Table 20 shows the activities, capsule fractions, and particle equivalents for selected isotopes measured on the capsule hardware. Table 21 represents the available (incomplete) mass balance for Capsule 9 (sink ring, foils, felts, spacers, and through tubes).

Table 20. Summary of inventories of select isotopes on Capsule 9 hardware. Shaded cells are based entirely on MDAs or cases where MDAs account for $>50 \%$ of a sum of MDAs and measured values.

\begin{tabular}{|c|c|c|c|c|c|c|}
\hline Capsule 9 & Foils & Felts $^{\text {a }}$ & Spacers & $\begin{array}{c}\text { Through } \\
\text { Tubes }\end{array}$ & $\begin{array}{c}\text { Total } \\
\text { (measured } \\
+ \text { MDA) } \\
\end{array}$ & $\begin{array}{c}\text { Total } \\
\text { (measured } \\
\text { only) }\end{array}$ \\
\hline \multicolumn{7}{|c|}{ Decay-Corrected Activity (Bq) } \\
\hline Ag-110m & $1.30 \mathrm{E}+05$ & $9.62 \mathrm{E}+04$ & $8.34 \mathrm{E}+04$ & $1.45 \mathrm{E}+06$ & $1.76 \mathrm{E}+06$ & $1.45 \mathrm{E}+06$ \\
\hline Cs-134 & $4.38 \mathrm{E}+06$ & $2.51 \mathrm{E}+05$ & $1.94 \mathrm{E}+05$ & $3.00 \mathrm{E}+05$ & $5.13 \mathrm{E}+06$ & $5.13 \mathrm{E}+06$ \\
\hline Cs-137 & $5.27 \mathrm{E}+06$ & $1.89 \mathrm{E}+05$ & $1.20 \mathrm{E}+05$ & $3.78 \mathrm{E}+05$ & $5.96 \mathrm{E}+06$ & $5.96 \mathrm{E}+06$ \\
\hline $\mathrm{Ce}-144$ & $7.32 \mathrm{E}+05$ & $2.18 \mathrm{E}+04$ & $2.54 \mathrm{E}+05$ & $3.91 \mathrm{E}+05$ & $1.40 \mathrm{E}+06$ & 0 \\
\hline Eu-154 & $7.69 \mathrm{E}+03$ & $2.45 \mathrm{E}+02$ & $3.03 \mathrm{E}+05$ & $2.13 \mathrm{E}+04$ & $3.33 \mathrm{E}+05$ & $3.04 \mathrm{E}+05$ \\
\hline Sr-90 & $8.99 \mathrm{E}+03$ & $\mathrm{~b}$ & $4.06 \mathrm{E}+03$ & $1.51 \mathrm{E}+04$ & $2.82 \mathrm{E}+04$ & $2.82 \mathrm{E}+04$ \\
\hline \multicolumn{7}{|c|}{ Capsule Fraction } \\
\hline Ag-110m & $3.71 \mathrm{E}-04$ & $2.75 \mathrm{E}-04$ & $2.38 \mathrm{E}-04$ & $4.15 \mathrm{E}-03$ & $5.03 \mathrm{E}-03$ & 4.15E-03 \\
\hline Cs-134 & $1.34 \mathrm{E}-04$ & $7.70 \mathrm{E}-06$ & 5.94E-06 & $9.20 \mathrm{E}-06$ & $1.57 \mathrm{E}-04$ & $1.57 \mathrm{E}-04$ \\
\hline Cs-137 & $1.92 \mathrm{E}-04$ & $6.90 \mathrm{E}-06$ & $4.36 \mathrm{E}-06$ & $1.38 \mathrm{E}-05$ & $2.17 \mathrm{E}-04$ & $2.17 \mathrm{E}-04$ \\
\hline $\mathrm{Ce}-144$ & $1.78 \mathrm{E}-06$ & $5.30 \mathrm{E}-08$ & $6.16 \mathrm{E}-07$ & $9.49 \mathrm{E}-07$ & 3.39E-06 & 0 \\
\hline Eu-154 & $7.43 \mathrm{E}-06$ & $2.37 \mathrm{E}-07$ & $2.93 \mathrm{E}-04$ & $2.06 \mathrm{E}-05$ & $3.21 \mathrm{E}-04$ & $2.93 \mathrm{E}-04$ \\
\hline Sr-90 & $3.78 \mathrm{E}-07$ & $\mathrm{~b}$ & $1.71 \mathrm{E}-07$ & $6.37 \mathrm{E}-07$ & $1.19 \mathrm{E}-06$ & $1.19 \mathrm{E}-06$ \\
\hline \multicolumn{7}{|c|}{ Particle Equivalents } \\
\hline $\mathrm{Ag}-110 \mathrm{~m}$ & $2.81 \mathrm{E}+00$ & $2.08 \mathrm{E}+00$ & $1.80 \mathrm{E}+00$ & $3.14 \mathrm{E}+01$ & $3.81 \mathrm{E}+01$ & $3.14 \mathrm{E}+01$ \\
\hline Cs-134 & $1.02 \mathrm{E}+00$ & $5.82 \mathrm{E}-02$ & $4.50 \mathrm{E}-02$ & $6.96 \mathrm{E}-02$ & $1.19 \mathrm{E}+00$ & $1.19 \mathrm{E}+00$ \\
\hline Cs-137 & $1.45 \mathrm{E}+00$ & $5.22 \mathrm{E}-02$ & $3.30 \mathrm{E}-02$ & $1.04 \mathrm{E}-01$ & $1.64 \mathrm{E}+00$ & $1.64 \mathrm{E}+00$ \\
\hline $\mathrm{Ce}-144$ & $1.34 \mathrm{E}-02$ & $4.01 \mathrm{E}-04$ & $4.66 \mathrm{E}-03$ & $7.18 \mathrm{E}-03$ & $2.57 \mathrm{E}-02$ & 0 \\
\hline Eu-154 & $5.63 \mathrm{E}-02$ & $1.79 \mathrm{E}-03$ & $2.22 \mathrm{E}+00$ & $1.56 \mathrm{E}-01$ & $2.43 \mathrm{E}+00$ & $2.22 \mathrm{E}+00$ \\
\hline Sr-90 & $2.86 \mathrm{E}-03$ & $\mathrm{~b}$ & $1.29 \mathrm{E}-03$ & $4.82 \mathrm{E}-03$ & $8.98 \mathrm{E}-03$ & $8.98 \mathrm{E}-03$ \\
\hline
\end{tabular}


Table 21. Inventories in capsule rings, total hardware (Total of measured + MDA from Table 20), and available inventory measured outside of the fuel ("Grand Total measured + MDA" and "Grand Total measured only"). Capsule 9 is an intact fuel body. Inner and outer rings were not measured. Errors are given based on propagation of uncertainty across the sum of all measured values. Shaded cells are based entirely on MDAs or cases where MDAs account for $>50 \%$ of a sum of MDAs and measured values.

\begin{tabular}{|c|c|c|c|c|c|c|c|c|}
\hline Capsule 9 & $\begin{array}{c}\text { Inner } \\
\text { Ring }\end{array}$ & $\begin{array}{c}\text { Outer } \\
\text { Ring } \\
\end{array}$ & $\begin{array}{l}\text { Sink } \\
\text { Ring }\end{array}$ & $\begin{array}{c}\text { Hardware } \\
\text { (measured } \\
+ \text { MDA) }\end{array}$ & $\begin{array}{c}\begin{array}{c}\text { Grand } \\
\text { Total } \\
\text { (measured } \\
+ \text { MDA) }\end{array} \\
\end{array}$ & $\begin{array}{c}\begin{array}{c}\text { Grand } \\
\text { Total } \\
\text { (measured } \\
\text { only) }\end{array} \\
\end{array}$ & $\begin{array}{c}\begin{array}{c}\text { Error } \\
(\% \text { minus })\end{array} \\
\end{array}$ & $\begin{array}{c}\text { Error } \\
\text { (\% plus) }\end{array}$ \\
\hline $\begin{array}{c}\text { Ring } \\
\text { Material }\end{array}$ & Matrix & IG-110 & PCEA & N/A & N/A & N/A & N/A & N/A \\
\hline $\begin{array}{c}\text { TAVA } \\
\text { Temp }\left({ }^{\circ} \mathrm{C}\right)\end{array}$ & 822 & 698 & 608 & N/A & N/A & N/A & N/A & N/A \\
\hline \multicolumn{9}{|c|}{ Decay-Corrected Activity (Bq) } \\
\hline $\mathrm{Ag}-110 \mathrm{~m}$ & $\mathrm{~N} / \mathrm{A}$ & $\mathrm{N} / \mathrm{A}$ & $1.21 \mathrm{E}+06$ & $1.76 \mathrm{E}+06$ & $2.97 \mathrm{E}+06$ & $1.45 \mathrm{E}+06$ & $1.5 \%$ & $1.5 \%$ \\
\hline Cs-134 & $\mathrm{N} / \mathrm{A}$ & $\mathrm{N} / \mathrm{A}$ & $4.38 \mathrm{E}+06$ & $5.13 \mathrm{E}+06$ & $9.51 \mathrm{E}+06$ & $9.51 \mathrm{E}+06$ & $4.0 \%$ & $4.0 \%$ \\
\hline Cs-137 & $\mathrm{N} / \mathrm{A}$ & $\mathrm{N} / \mathrm{A}$ & $1.24 \mathrm{E}+07$ & $5.96 \mathrm{E}+06$ & $1.84 \mathrm{E}+07$ & $1.84 \mathrm{E}+07$ & $3.7 \%$ & $3.7 \%$ \\
\hline $\mathrm{Ce}-144$ & $\mathrm{~N} / \mathrm{A}$ & $\mathrm{N} / \mathrm{A}$ & $8.58 \mathrm{E}+06$ & $1.40 \mathrm{E}+06$ & $9.98 \mathrm{E}+06$ & 0 & & \\
\hline Eu-154 & $\mathrm{N} / \mathrm{A}$ & $\mathrm{N} / \mathrm{A}$ & $1.85 \mathrm{E}+05$ & $3.33 \mathrm{E}+05$ & $5.17 \mathrm{E}+05$ & $3.04 \mathrm{E}+05$ & $3.0 \%$ & $3.0 \%$ \\
\hline Sr-90 & N/A & N/A & $8.34 \mathrm{E}+04$ & $2.82 \mathrm{E}+04$ & $1.12 \mathrm{E}+05$ & $1.12 \mathrm{E}+05$ & $1.5 \%$ & $1.5 \%$ \\
\hline \multicolumn{9}{|c|}{ Capsule Fraction } \\
\hline $\mathrm{Ag}-110 \mathrm{~m}$ & N/A & $\mathrm{N} / \mathrm{A}$ & $3.46 \mathrm{E}-03$ & $5.03 \mathrm{E}-03$ & $8.49 \mathrm{E}-03$ & 4.15E-03 & $1.5 \%$ & $1.5 \%$ \\
\hline Cs-134 & $\mathrm{N} / \mathrm{A}$ & N/A & $1.34 \mathrm{E}-04$ & $1.57 \mathrm{E}-04$ & 2.91E-04 & 2.91E-04 & $4.0 \%$ & $4.0 \%$ \\
\hline Cs-137 & $\mathrm{N} / \mathrm{A}$ & $\mathrm{N} / \mathrm{A}$ & 4.52E-04 & $2.17 \mathrm{E}-04$ & $6.70 \mathrm{E}-04$ & $6.70 \mathrm{E}-04$ & $3.7 \%$ & $3.7 \%$ \\
\hline $\mathrm{Ce}-144$ & N/A & N/A & $2.08 \mathrm{E}-05$ & $3.39 \mathrm{E}-06$ & $2.42 \mathrm{E}-05$ & 0 & & \\
\hline Eu-154 & $\mathrm{N} / \mathrm{A}$ & $\mathrm{N} / \mathrm{A}$ & $1.79 \mathrm{E}-04$ & $3.21 \mathrm{E}-04$ & $5.00 \mathrm{E}-04$ & $2.93 \mathrm{E}-04$ & $3.0 \%$ & $3.0 \%$ \\
\hline Sr-90 & N/A & N/A & $3.51 \mathrm{E}-06$ & $1.19 \mathrm{E}-06$ & $4.70 \mathrm{E}-06$ & 4.70E-06 & $1.5 \%$ & $1.5 \%$ \\
\hline \multicolumn{9}{|c|}{ Particle Equivalents } \\
\hline $\mathrm{Ag}-110 \mathrm{~m}$ & $\mathrm{~N} / \mathrm{A}$ & $\mathrm{N} / \mathrm{A}$ & $2.62 \mathrm{E}+01$ & $3.81 \mathrm{E}+01$ & $6.43 \mathrm{E}+01$ & $3.14 \mathrm{E}+01$ & $1.5 \%$ & $1.5 \%$ \\
\hline Cs-134 & $\mathrm{N} / \mathrm{A}$ & N/A & $1.01 \mathrm{E}+00$ & $1.19 \mathrm{E}+00$ & $2.20 \mathrm{E}+00$ & $2.20 \mathrm{E}+00$ & $4.0 \%$ & $4.0 \%$ \\
\hline Cs-137 & N/A & N/A & $3.42 \mathrm{E}+00$ & $1.64 \mathrm{E}+00$ & $5.07 \mathrm{E}+00$ & $5.07 \mathrm{E}+00$ & $3.7 \%$ & $3.7 \%$ \\
\hline $\mathrm{Ce}-144$ & N/A & N/A & $1.58 \mathrm{E}-01$ & $2.57 \mathrm{E}-02$ & $1.83 \mathrm{E}-01$ & $0.00 \mathrm{E}+00$ & & \\
\hline Eu-154 & N/A & N/A & $1.35 \mathrm{E}+00$ & $2.43 \mathrm{E}+00$ & $3.78 \mathrm{E}+00$ & $2.22 \mathrm{E}+00$ & $3.0 \%$ & $3.0 \%$ \\
\hline Sr-90 & N/A & N/A & $2.66 \mathrm{E}-02$ & $8.98 \mathrm{E}-03$ & $3.56 \mathrm{E}-02$ & $3.56 \mathrm{E}-02$ & $1.5 \%$ & $1.5 \%$ \\
\hline
\end{tabular}




\subsection{Capsule 10}

Capsule 10 was a standard-type capsule and was among the hottest three capsules in the irradiation. Table 22 shows the activities, capsule fractions, and particle equivalents for selected isotopes measured on the capsule hardware. The high radioactivity on the felts caused too high a dead-time to make an accurate measurement on the HOGS detector. The screws recovered from the sink ring (which were originally packaged together with the felts) were separated from the felts and counted on the HOGS. The felts were transferred to AL and counted there. Table 23 represents the entire mass balance for Capsule 10 (inner ring, outer ring, sink ring, foils, felts, spacers, and through tubes).

Table 22. Summary of inventories of select isotopes on Capsule 10 hardware. Shaded cells are based entirely on MDAs or cases where MDAs account for $>50 \%$ of a sum of MDAs and measured values.

\begin{tabular}{|c|c|c|c|c|c|c|}
\hline Capsule 10 & Foils & Felts $^{\mathrm{a}}$ & Spacers & Through Tubes & $\begin{array}{c}\text { Total } \\
\text { (measured } \\
+ \text { MDA) } \\
\end{array}$ & $\begin{array}{c}\text { Total } \\
\text { (measured } \\
\text { only) }\end{array}$ \\
\hline \multicolumn{7}{|c|}{ Decay-Corrected Activity (Bq) } \\
\hline Ag-110m & $1.10 \mathrm{E}+05$ & $2.29 \mathrm{E}+06$ & $8.47 \mathrm{E}+04$ & $9.72 \mathrm{E}+05$ & $3.46 \mathrm{E}+06$ & $9.72 \mathrm{E}+05$ \\
\hline Cs-134 & $1.90 \mathrm{E}+06$ & $2.01 \mathrm{E}+07$ & $2.71 \mathrm{E}+06$ & $2.02 \mathrm{E}+06$ & $2.68 \mathrm{E}+07$ & $2.68 \mathrm{E}+07$ \\
\hline Cs-137 & $4.49 \mathrm{E}+06$ & $2.22 \mathrm{E}+07$ & $3.06 \mathrm{E}+06$ & $2.67 \mathrm{E}+06$ & $3.25 \mathrm{E}+07$ & $3.25 \mathrm{E}+07$ \\
\hline Ce-144 & $5.33 \mathrm{E}+05$ & $1.40 \mathrm{E}+06$ & $3.60 \mathrm{E}+05$ & $3.48 \mathrm{E}+05$ & $2.64 \mathrm{E}+06$ & $3.60 \mathrm{E}+05$ \\
\hline Eu-154 & $9.76 \mathrm{E}+04$ & $3.02 \mathrm{E}+03$ & $4.13 \mathrm{E}+05$ & $2.13 \mathrm{E}+04$ & $5.35 \mathrm{E}+05$ & $5.11 \mathrm{E}+05$ \\
\hline Sr-90 & $5.66 \mathrm{E}+06$ & $\mathrm{~b}$ & $9.47 \mathrm{E}+03$ & $1.05 \mathrm{E}+04$ & $5.68 \mathrm{E}+06$ & $5.68 \mathrm{E}+06$ \\
\hline \multicolumn{7}{|c|}{ Capsule Fraction } \\
\hline $\mathrm{Ag}-110 \mathrm{~m}$ & 4.84E-04 & $1.01 \mathrm{E}-02$ & $3.72 \mathrm{E}-04$ & 4.27E-03 & $1.52 \mathrm{E}-02$ & $4.27 \mathrm{E}-03$ \\
\hline Cs-134 & $8.10 \mathrm{E}-05$ & 8.59E-04 & $1.15 \mathrm{E}-04$ & $8.63 \mathrm{E}-05$ & $1.14 \mathrm{E}-03$ & $1.14 \mathrm{E}-03$ \\
\hline Cs-137 & $1.90 \mathrm{E}-04$ & $9.39 \mathrm{E}-04$ & $1.29 \mathrm{E}-04$ & $1.13 \mathrm{E}-04$ & $1.37 \mathrm{E}-03$ & $1.37 \mathrm{E}-03$ \\
\hline Ce-144 & $1.47 \mathrm{E}-06$ & $3.85 \mathrm{E}-06$ & $9.91 \mathrm{E}-07$ & $9.56 \mathrm{E}-07$ & $7.27 \mathrm{E}-06$ & $9.91 \mathrm{E}-07$ \\
\hline $\mathrm{Eu}-154$ & $1.26 \mathrm{E}-04$ & $3.90 \mathrm{E}-06$ & $5.35 \mathrm{E}-04$ & $2.75 \mathrm{E}-05$ & $6.92 \mathrm{E}-04$ & 6.61E-04 \\
\hline Sr-90 & $2.72 \mathrm{E}-04$ & $\mathrm{~b}$ & 4.54E-07 & $5.03 \mathrm{E}-07$ & $2.73 \mathrm{E}-04$ & $2.73 \mathrm{E}-04$ \\
\hline \multicolumn{7}{|c|}{ Particle Equivalents } \\
\hline $\mathrm{Ag}-110 \mathrm{~m}$ & $3.66 \mathrm{E}+00$ & $7.63 \mathrm{E}+01$ & $2.82 \mathrm{E}+00$ & $3.23 \mathrm{E}+01$ & $1.15 \mathrm{E}+02$ & $3.23 \mathrm{E}+01$ \\
\hline Cs-134 & $6.13 \mathrm{E}-01$ & $6.50 \mathrm{E}+00$ & $8.74 \mathrm{E}-01$ & $6.53 \mathrm{E}-01$ & $8.64 \mathrm{E}+00$ & $8.64 \mathrm{E}+00$ \\
\hline Cs-137 & $1.43 \mathrm{E}+00$ & $7.11 \mathrm{E}+00$ & $9.79 \mathrm{E}-01$ & $8.52 \mathrm{E}-01$ & $1.04 \mathrm{E}+01$ & $1.04 \mathrm{E}+01$ \\
\hline Ce-144 & $1.11 \mathrm{E}-02$ & $2.92 \mathrm{E}-02$ & $7.50 \mathrm{E}-03$ & 7.24E-03 & $5.50 \mathrm{E}-02$ & $7.50 \mathrm{E}-03$ \\
\hline Eu-154 & $9.55 \mathrm{E}-01$ & $2.95 \mathrm{E}-02$ & $4.05 \mathrm{E}+00$ & $2.08 \mathrm{E}-01$ & $5.24 \mathrm{E}+00$ & $5.00 \mathrm{E}+00$ \\
\hline Sr-90 & $2.06 \mathrm{E}+00$ & $\mathrm{~b}$ & $3.44 \mathrm{E}-03$ & $3.81 \mathrm{E}-03$ & $2.06 \mathrm{E}+00$ & $2.06 \mathrm{E}+00$ \\
\hline
\end{tabular}


Table 23. Inventories in capsule rings, total hardware (Total of measured + MDA from Table 22), and total inventory measured outside of the fuel ("Grand Total measured + MDA" and "Grand Total measured only"). Errors are given based on propagation of uncertainty across the sum of all measured values. Shaded cells are based entirely on MDAs or cases where MDAs account for $>50 \%$ of a sum of MDAs and measured values.

\begin{tabular}{|c|c|c|c|c|c|c|c|c|}
\hline Capsule 10 & $\begin{array}{c}\text { Inner } \\
\text { Ring }\end{array}$ & $\begin{array}{c}\text { Outer } \\
\text { Ring }\end{array}$ & $\begin{array}{l}\text { Sink } \\
\text { Ring }\end{array}$ & $\begin{array}{c}\text { Hardware } \\
\text { (measured } \\
+ \text { MDA) } \\
\end{array}$ & $\begin{array}{c}\text { Grand } \\
\text { Total } \\
\text { (measured } \\
+ \text { MDA) }\end{array}$ & $\begin{array}{c}\text { Grand } \\
\text { Total } \\
\text { (measured } \\
\text { only) }\end{array}$ & $\begin{array}{c}\text { Error } \\
\text { (\% minus) } \\
\end{array}$ & $\begin{array}{c}\text { Error } \\
\text { (\% plus) }\end{array}$ \\
\hline $\begin{array}{c}\text { Ring } \\
\text { Material }\end{array}$ & PCEA & PCEA & PCEA & N/A & $\mathrm{N} / \mathrm{A}$ & N/A & N/A & N/A \\
\hline $\begin{array}{c}\text { TAVA } \\
\text { Temp }\left({ }^{\circ} \mathrm{C}\right)\end{array}$ & 1038 & 971 & 646 & N/A & N/A & N/A & N/A & N/A \\
\hline \multicolumn{9}{|c|}{ Decay-Corrected Activity (Bq) } \\
\hline $\mathrm{Ag}-110 \mathrm{~m}$ & $2.07 \mathrm{E}+07$ & $8.99 \mathrm{E}+07$ & $5.20 \mathrm{E}+07$ & $3.46 \mathrm{E}+06$ & $1.66 \mathrm{E}+08$ & $1.66 \mathrm{E}+08$ & $1.9 \%$ & $2.0 \%$ \\
\hline Cs-134 & $1.97 \mathrm{E}+07$ & $2.76 \mathrm{E}+07$ & $6.03 \mathrm{E}+07$ & $2.68 \mathrm{E}+07$ & $1.34 \mathrm{E}+08$ & $1.34 \mathrm{E}+08$ & $3.0 \%$ & $3.0 \%$ \\
\hline Cs-137 & $2.38 \mathrm{E}+07$ & $3.17 \mathrm{E}+07$ & $6.93 \mathrm{E}+07$ & $3.25 \mathrm{E}+07$ & $1.57 \mathrm{E}+08$ & $1.57 \mathrm{E}+08$ & $2.8 \%$ & $2.8 \%$ \\
\hline $\mathrm{Ce}-144$ & $\mathrm{~N} / \mathrm{D}$ & $\mathrm{N} / \mathrm{D}$ & $3.68 \mathrm{E}+06$ & $2.64 \mathrm{E}+06$ & $6.33 \mathrm{E}+06$ & $3.60 \mathrm{E}+05$ & $29.0 \%$ & $29.0 \%$ \\
\hline Eu-154 & $3.48 \mathrm{E}+05$ & $3.70 \mathrm{E}+04$ & $5.87 \mathrm{E}+04$ & $5.35 \mathrm{E}+05$ & $9.79 \mathrm{E}+05$ & $8.96 \mathrm{E}+05$ & $8.8 \%$ & $98.5 \%$ \\
\hline Sr-90 & a & a & $1.07 \mathrm{E}+05$ & $5.68 \mathrm{E}+06$ & $5.79 \mathrm{E}+06$ & $5.79 \mathrm{E}+06$ & $3.4 \%$ & $3.4 \%$ \\
\hline \multicolumn{9}{|c|}{ Capsule Fraction } \\
\hline $\mathrm{Ag}-110 \mathrm{~m}$ & $9.10 \mathrm{E}-02$ & $3.95 \mathrm{E}-01$ & $2.29 \mathrm{E}-01$ & $1.52 \mathrm{E}-02$ & $7.30 \mathrm{E}-01$ & 7.29E-01 & $1.9 \%$ & $2.0 \%$ \\
\hline Cs-134 & $8.42 \mathrm{E}-04$ & $1.18 \mathrm{E}-03$ & $2.57 \mathrm{E}-03$ & $1.14 \mathrm{E}-03$ & $5.74 \mathrm{E}-03$ & $5.74 \mathrm{E}-03$ & $3.0 \%$ & $3.0 \%$ \\
\hline Cs-137 & $1.01 \mathrm{E}-03$ & $1.34 \mathrm{E}-03$ & $2.93 \mathrm{E}-03$ & $1.37 \mathrm{E}-03$ & $6.65 \mathrm{E}-03$ & $6.65 \mathrm{E}-03$ & $2.8 \%$ & $2.8 \%$ \\
\hline $\mathrm{Ce}-144$ & $\mathrm{~N} / \mathrm{D}$ & $\mathrm{N} / \mathrm{D}$ & $1.01 \mathrm{E}-05$ & $7.27 \mathrm{E}-06$ & $1.74 \mathrm{E}-05$ & $9.91 \mathrm{E}-07$ & $29.0 \%$ & $29.0 \%$ \\
\hline Eu-154 & $4.50 \mathrm{E}-04$ & $9.83 \mathrm{E}-05$ & $7.60 \mathrm{E}-05$ & $6.92 \mathrm{E}-04$ & $1.32 \mathrm{E}-03$ & $1.21 \mathrm{E}-03$ & $8.8 \%$ & $98.5 \%$ \\
\hline Sr-90 & a & a & $5.15 \mathrm{E}-06$ & $2.73 \mathrm{E}-04$ & $2.78 \mathrm{E}-04$ & $2.78 \mathrm{E}-04$ & $3.4 \%$ & $3.4 \%$ \\
\hline \multicolumn{9}{|c|}{ Particle Equivalents } \\
\hline $\mathrm{Ag}-110 \mathrm{~m}$ & $6.89 \mathrm{E}+02$ & $2.99 \mathrm{E}+03$ & $1.73 \mathrm{E}+03$ & $1.15 \mathrm{E}+02$ & $5.52 \mathrm{E}+03$ & $5.52 \mathrm{E}+03$ & $1.9 \%$ & $2.0 \%$ \\
\hline Cs-134 & $6.37 \mathrm{E}+00$ & $8.93 \mathrm{E}+00$ & $1.95 \mathrm{E}+01$ & $8.64 \mathrm{E}+00$ & $4.34 \mathrm{E}+01$ & $4.34 \mathrm{E}+01$ & $3.0 \%$ & $3.0 \%$ \\
\hline Cs-137 & $7.64 \mathrm{E}+00$ & $1.01 \mathrm{E}+01$ & $2.22 \mathrm{E}+01$ & $1.04 \mathrm{E}+01$ & $5.03 \mathrm{E}+01$ & $5.03 \mathrm{E}+01$ & $2.8 \%$ & $2.8 \%$ \\
\hline $\mathrm{Ce}-144$ & N/D & $\mathrm{N} / \mathrm{D}$ & 7.67E-02 & $5.50 \mathrm{E}-02$ & $1.32 \mathrm{E}-01$ & $7.50 \mathrm{E}-03$ & $29.0 \%$ & $29.0 \%$ \\
\hline Eu-154 & $3.41 \mathrm{E}+00$ & $7.44 \mathrm{E}-01$ & $5.75 \mathrm{E}-01$ & $5.24 \mathrm{E}+00$ & $9.96 \mathrm{E}+00$ & $9.15 \mathrm{E}+00$ & $8.8 \%$ & $98.5 \%$ \\
\hline Sr-90 & $\mathrm{a}$ & a & $3.89 \mathrm{E}-02$ & $2.06 \mathrm{E}+00$ & $2.10 \mathrm{E}+00$ & $2.10 \mathrm{E}+00$ & $3.4 \%$ & $3.4 \%$ \\
\hline \multicolumn{9}{|c|}{$\begin{array}{ll}\text { N/A } & \text { not applicable. } \\
\text { N/D } & \text { not detected on PGS, no MDAs determined. } \\
\text { a. } & \text { requires destructive analysis to measure. }\end{array}$} \\
\hline
\end{tabular}




\subsection{Capsule 11}

Capsule 11 was a fuel body capsule, and this fuel body was not disassembled; therefore, neither the compacts nor the inner and outer rings could be scanned via PGS. Table 24 shows the activities, capsule fractions, and particle equivalents for selected isotopes measured on the capsule hardware. The foil burnleach Sr-90 analysis was carried out in triplicate, and these results were averaged. The duplicate sample had roughly 10 times lower Sr-90 (and gamma activity) than the other two samples. It is hypothesized that the in-cell dilution of the duplicate sample was not done correctly. If this sample is not included in the average Sr-90 activity, the activity increases to $7.23 \mathrm{E} 3 \mathrm{~Bq}$ from $6.57 \mathrm{E} 3 \mathrm{~Bq}$. Table 25 represents the available (incomplete) mass balance for Capsule 11 (sink ring, foils, felts, spacers, and through tubes).

Table 24. Summary of inventories of select isotopes on Capsule 11 hardware. Shaded cells are based entirely on MDAs or cases where MDAs account for $>50 \%$ of a sum of MDAs and measured values.

\begin{tabular}{|c|c|c|c|c|c|c|}
\hline Capsule 11 & Foils & Felts $^{\mathrm{a}}$ & Spacers & $\begin{array}{c}\text { Through } \\
\text { Tubes }\end{array}$ & $\begin{array}{c}\text { Total } \\
\text { (measured } \\
+ \text { MDA) } \\
\end{array}$ & $\begin{array}{c}\text { Total } \\
\text { (measured } \\
\text { only) }\end{array}$ \\
\hline \multicolumn{7}{|c|}{ Decay-Corrected Activity (Bq) } \\
\hline Ag-110m & $1.00 \mathrm{E}+05$ & $2.15 \mathrm{E}+07$ & $1.04 \mathrm{E}+05$ & $9.94 \mathrm{E}+05$ & $2.27 \mathrm{E}+07$ & $9.94 \mathrm{E}+05$ \\
\hline Cs-134 & $3.41 \mathrm{E}+06$ & $6.97 \mathrm{E}+06$ & $8.61 \mathrm{E}+05$ & $1.26 \mathrm{E}+06$ & $1.25 \mathrm{E}+07$ & $1.25 \mathrm{E}+07$ \\
\hline Cs-137 & $7.34 \mathrm{E}+06$ & $6.36 \mathrm{E}+06$ & $1.09 \mathrm{E}+06$ & $2.32 \mathrm{E}+06$ & $1.71 \mathrm{E}+07$ & $1.71 \mathrm{E}+07$ \\
\hline Ce-144 & $3.34 \mathrm{E}+05$ & $1.92 \mathrm{E}+04$ & $2.53 \mathrm{E}+05$ & $3.04 \mathrm{E}+05$ & $9.11 \mathrm{E}+05$ & $5.87 \mathrm{E}+05$ \\
\hline Eu-154 & $1.78 \mathrm{E}+05$ & $3.29 \mathrm{E}+04$ & $9.69 \mathrm{E}+05$ & $2.13 \mathrm{E}+04$ & $1.20 \mathrm{E}+06$ & $1.18 \mathrm{E}+06$ \\
\hline Sr-90 & $6.57 \mathrm{E}+03$ & $\mathrm{~b}$ & $3.85 \mathrm{E}+03$ & $5.40 \mathrm{E}+03$ & $1.58 \mathrm{E}+04$ & $1.58 \mathrm{E}+04$ \\
\hline \multicolumn{7}{|c|}{ Capsule Fraction } \\
\hline Ag-110m & $9.44 \mathrm{E}-04$ & $2.02 \mathrm{E}-01$ & 9.79E-04 & $9.36 \mathrm{E}-03$ & 2.13E-01 & $9.36 \mathrm{E}-03$ \\
\hline Cs-134 & $2.56 \mathrm{E}-04$ & 5.24E-04 & $6.48 \mathrm{E}-05$ & $9.46 \mathrm{E}-05$ & $9.40 \mathrm{E}-04$ & $9.40 \mathrm{E}-04$ \\
\hline Cs-137 & 4.04E-04 & $3.50 \mathrm{E}-04$ & $5.98 \mathrm{E}-05$ & $1.28 \mathrm{E}-04$ & $9.42 \mathrm{E}-04$ & $9.42 \mathrm{E}-04$ \\
\hline Ce-144 & $1.16 \mathrm{E}-06$ & $6.70 \mathrm{E}-08$ & $8.81 \mathrm{E}-07$ & $1.06 \mathrm{E}-06$ & $3.17 \mathrm{E}-06$ & $2.04 \mathrm{E}-06$ \\
\hline Eu-154 & $3.98 \mathrm{E}-04$ & 7.34E-05 & $2.16 \mathrm{E}-03$ & 4.75E-05 & $2.68 \mathrm{E}-03$ & $2.63 \mathrm{E}-03$ \\
\hline Sr-90 & 4.01E-07 & $\mathrm{b}$ & $2.35 \mathrm{E}-07$ & $3.30 \mathrm{E}-07$ & $9.66 \mathrm{E}-07$ & $9.66 \mathrm{E}-07$ \\
\hline \multicolumn{7}{|c|}{ Particle Equivalents } \\
\hline Ag-110m & $7.14 \mathrm{E}+00$ & $1.53 \mathrm{E}+03$ & $7.41 \mathrm{E}+00$ & $7.09 \mathrm{E}+01$ & $1.61 \mathrm{E}+03$ & $7.09 \mathrm{E}+01$ \\
\hline Cs-134 & $1.94 \mathrm{E}+00$ & $3.97 \mathrm{E}+00$ & 4.90E-01 & $7.16 \mathrm{E}-01$ & $7.11 \mathrm{E}+00$ & $7.11 \mathrm{E}+00$ \\
\hline Cs-137 & $3.06 \mathrm{E}+00$ & $2.65 \mathrm{E}+00$ & 4.53E-01 & $9.67 \mathrm{E}-01$ & $7.13 \mathrm{E}+00$ & $7.13 \mathrm{E}+00$ \\
\hline Ce-144 & 8.81E-03 & $5.07 \mathrm{E}-04$ & $6.67 \mathrm{E}-03$ & $8.02 \mathrm{E}-03$ & $2.40 \mathrm{E}-02$ & $1.55 \mathrm{E}-02$ \\
\hline Eu-154 & $3.01 \mathrm{E}+00$ & $5.55 \mathrm{E}-01$ & $1.64 \mathrm{E}+01$ & $3.59 \mathrm{E}-01$ & $2.03 \mathrm{E}+01$ & $1.99 \mathrm{E}+01$ \\
\hline Sr-90 & $3.04 \mathrm{E}-03$ & $\mathrm{~b}$ & $1.78 \mathrm{E}-03$ & 2.49E-03 & 7.31E-03 & $7.31 \mathrm{E}-03$ \\
\hline
\end{tabular}


Table 25. Inventories in sink ring, hardware (Total of measured + MDA from Table 24), and available inventory measured outside of the fuel ("Grand total measured + MDA" and "Grand total measured only"). Inner and outer rings not measured. Errors are given based on propagation of uncertainty across the sum of all measured values. Shaded cells are based entirely on MDAs or cases where MDAs account for $>50 \%$ of a sum of MDAs and measured values.

\begin{tabular}{|c|c|c|c|c|c|c|c|c|}
\hline Capsule 11 & $\begin{array}{c}\text { Inner } \\
\text { Ring }\end{array}$ & $\begin{array}{c}\text { Outer } \\
\text { Ring }\end{array}$ & $\begin{array}{l}\text { Sink } \\
\text { Ring } \\
\end{array}$ & $\begin{array}{c}\text { Hardware } \\
\text { (measured } \\
+ \text { MDA) }\end{array}$ & $\begin{array}{c}\begin{array}{c}\text { Grand } \\
\text { total } \\
\text { (measured } \\
+ \text { MDA) }\end{array} \\
\end{array}$ & $\begin{array}{c}\begin{array}{c}\text { Grand } \\
\text { total } \\
\text { (measured } \\
\text { only) }\end{array} \\
\end{array}$ & $\begin{array}{c}\text { Error } \\
\text { (\% minus) } \\
\end{array}$ & $\begin{array}{c}\text { Error } \\
\text { (\% plus) }\end{array}$ \\
\hline $\begin{array}{c}\text { Ring } \\
\text { Material }\end{array}$ & Matrix & PCEA & PCEA & N/A & N/A & N/A & N/A & N/A \\
\hline $\begin{array}{c}\text { TAVA } \\
\text { Temp }\left({ }^{\circ} \mathrm{C}\right)\end{array}$ & 1124 & 966 & 737 & N/A & N/A & N/A & N/A & N/A \\
\hline \multicolumn{9}{|c|}{ Decay-Corrected Activity (Bq) } \\
\hline $\mathrm{Ag}-110 \mathrm{~m}$ & a & $\mathrm{a}$ & $4.78 \mathrm{E}+06$ & $2.27 \mathrm{E}+07$ & $2.74 \mathrm{E}+07$ & $5.78 \mathrm{E}+06$ & $5.8 \%$ & $5.8 \%$ \\
\hline Cs-134 & a & a & $3.41 \mathrm{E}+07$ & $1.25 \mathrm{E}+07$ & $4.66 \mathrm{E}+07$ & $4.66 \mathrm{E}+07$ & $4.5 \%$ & $4.5 \%$ \\
\hline Cs-137 & a & a & $5.93 \mathrm{E}+07$ & $1.71 \mathrm{E}+07$ & $7.64 \mathrm{E}+07$ & $7.64 \mathrm{E}+07$ & $4.5 \%$ & $4.5 \%$ \\
\hline Ce-144 & a & a & $8.56 \mathrm{E}+06$ & $9.11 \mathrm{E}+05$ & $9.47 \mathrm{E}+06$ & $3.34 \mathrm{E}+05$ & $15.0 \%$ & $15.0 \%$ \\
\hline Eu-154 & a & a & $7.66 \mathrm{E}+04$ & $1.20 \mathrm{E}+06$ & $1.28 \mathrm{E}+06$ & $1.18 \mathrm{E}+06$ & $4.5 \%$ & $4.5 \%$ \\
\hline Sr-90 & a & a & $2.31 \mathrm{E}+05$ & $1.58 \mathrm{E}+04$ & $2.47 \mathrm{E}+05$ & $2.47 \mathrm{E}+05$ & $1.5 \%$ & $1.5 \%$ \\
\hline \multicolumn{9}{|c|}{ Capsule Fraction } \\
\hline $\mathrm{Ag}-110 \mathrm{~m}$ & $\mathrm{a}$ & a & $4.50 \mathrm{E}-02$ & $2.13 \mathrm{E}-01$ & $2.58 \mathrm{E}-01$ & $5.44 \mathrm{E}-02$ & $5.8 \%$ & $5.8 \%$ \\
\hline Cs-134 & $\mathrm{a}$ & $\mathrm{a}$ & $2.57 \mathrm{E}-03$ & $9.40 \mathrm{E}-04$ & $3.51 \mathrm{E}-03$ & $3.51 \mathrm{E}-03$ & $4.5 \%$ & $4.5 \%$ \\
\hline Cs-137 & a & a & $3.27 \mathrm{E}-03$ & $9.42 \mathrm{E}-04$ & $4.21 \mathrm{E}-03$ & $4.21 \mathrm{E}-03$ & $4.5 \%$ & $4.5 \%$ \\
\hline Ce-144 & a & a & $2.98 \mathrm{E}-05$ & $3.17 \mathrm{E}-06$ & $3.30 \mathrm{E}-05$ & $1.16 \mathrm{E}-06$ & $15.0 \%$ & $15.0 \%$ \\
\hline $\mathrm{Eu}-154$ & $\mathrm{a}$ & $\mathrm{a}$ & $1.71 \mathrm{E}-04$ & $2.68 \mathrm{E}-03$ & $2.85 \mathrm{E}-03$ & $2.63 \mathrm{E}-03$ & $4.5 \%$ & $4.5 \%$ \\
\hline Sr-90 & a & a & $1.41 \mathrm{E}-05$ & $9.66 \mathrm{E}-07$ & $1.51 \mathrm{E}-05$ & $1.51 \mathrm{E}-05$ & $1.5 \%$ & $1.5 \%$ \\
\hline \multicolumn{9}{|c|}{ Particle Equivalents } \\
\hline Ag-110m & $\mathrm{a}$ & a & $3.41 \mathrm{E}+02$ & $1.61 \mathrm{E}+03$ & $1.96 \mathrm{E}+03$ & 2.34E-01 & $5.8 \%$ & $5.8 \%$ \\
\hline Cs-134 & $\mathrm{a}$ & a & $1.94 \mathrm{E}+01$ & $7.11 \mathrm{E}+00$ & $2.65 \mathrm{E}+01$ & $3.18 \mathrm{E}+01$ & $4.5 \%$ & $4.5 \%$ \\
\hline Cs-137 & $\mathrm{a}$ & a & $2.47 \mathrm{E}+01$ & $7.13 \mathrm{E}+00$ & $3.18 \mathrm{E}+01$ & $2.16 \mathrm{E}+01$ & $4.5 \%$ & $4.5 \%$ \\
\hline Ce-144 & a & a & $2.26 \mathrm{E}-01$ & $2.40 \mathrm{E}-02$ & $2.50 \mathrm{E}-01$ & $0.00 \mathrm{E}+00$ & $15.0 \%$ & $15.0 \%$ \\
\hline $\mathrm{Eu}-154$ & a & a & $1.29 \mathrm{E}+00$ & $2.03 \mathrm{E}+01$ & $2.16 \mathrm{E}+01$ & $1.11 \mathrm{E}+01$ & $4.5 \%$ & $4.5 \%$ \\
\hline Sr-90 & $\mathrm{a}$ & a & $1.07 \mathrm{E}-01$ & 7.31E-03 & $1.14 \mathrm{E}-01$ & $0.00 \mathrm{E}+00$ & $1.5 \%$ & $1.5 \%$ \\
\hline
\end{tabular}




\subsection{Capsule 12}

Capsule 12 was a standard-type capsule, and Table 26 shows the activities, capsule fractions, and particle equivalents for selected isotopes measured on the capsule hardware. Table 27 represents the entire mass balance for Capsule 12 (inner ring, outer ring, sink ring, foils, felts, spacers, and through tubes).

Table 26. Summary of inventories of select isotopes on Capsule 12 hardware. Shaded cells are based entirely on MDAs or cases where MDAs account for $>50 \%$ of a sum of MDAs and measured values.

\begin{tabular}{|c|c|c|c|c|c|c|}
\hline Capsule 12 & Foils & Felts $^{\text {a }}$ & Spacers & $\begin{array}{c}\text { Through } \\
\text { Tubes }\end{array}$ & $\begin{array}{c}\text { Total } \\
\text { (measured } \\
+ \text { MDA) } \\
\end{array}$ & $\begin{array}{c}\text { Total } \\
\text { (measured } \\
\text { only) }\end{array}$ \\
\hline \multicolumn{7}{|c|}{ Decay-Corrected Activity (Bq) } \\
\hline Ag-110m & $2.42 \mathrm{E}+05$ & $3.70 \mathrm{E}+03$ & $8.81 \mathrm{E}+04$ & $9.73 \mathrm{E}+04$ & $4.31 \mathrm{E}+05$ & 0 \\
\hline Cs-134 & $1.69 \mathrm{E}+05$ & $1.52 \mathrm{E}+04$ & $4.94 \mathrm{E}+04$ & $1.17 \mathrm{E}+04$ & $2.45 \mathrm{E}+05$ & $2.45 \mathrm{E}+05$ \\
\hline Cs-137 & $4.38 \mathrm{E}+06$ & $2.39 \mathrm{E}+04$ & $1.02 \mathrm{E}+04$ & $4.33 \mathrm{E}+04$ & $4.46 \mathrm{E}+06$ & $4.46 \mathrm{E}+06$ \\
\hline $\mathrm{Ce}-144$ & $1.52 \mathrm{E}+06$ & $2.07 \mathrm{E}+04$ & $7.98 \mathrm{E}+05$ & $1.96 \mathrm{E}+05$ & $2.54 \mathrm{E}+06$ & 0 \\
\hline Eu-154 & $2.03 \mathrm{E}+04$ & $1.01 \mathrm{E}+04$ & $2.79 \mathrm{E}+05$ & $1.92 \mathrm{E}+04$ & $3.28 \mathrm{E}+05$ & $3.09 \mathrm{E}+05$ \\
\hline Sr-90 & $5.18 \mathrm{E}+03$ & $\mathrm{~b}$ & $2.79 \mathrm{E}+03$ & $1.94 \mathrm{E}+04$ & $2.74 \mathrm{E}+04$ & $2.74 \mathrm{E}+04$ \\
\hline \multicolumn{7}{|c|}{ Capsule Fraction } \\
\hline Ag-110m & $1.06 \mathrm{E}-02$ & $1.62 \mathrm{E}-04$ & $3.87 \mathrm{E}-03$ & 4.27E-03 & $1.89 \mathrm{E}-02$ & 0 \\
\hline Cs-134 & 4.12E-05 & $3.71 \mathrm{E}-06$ & $1.20 \mathrm{E}-05$ & $2.84 \mathrm{E}-06$ & 5.97E-05 & $5.97 \mathrm{E}-05$ \\
\hline Cs-137 & 4.10E-04 & $2.23 \mathrm{E}-06$ & $9.50 \mathrm{E}-07$ & $4.06 \mathrm{E}-06$ & 4.17E-04 & 4.17E-04 \\
\hline $\mathrm{Ce}-144$ & $8.68 \mathrm{E}-06$ & $1.18 \mathrm{E}-07$ & $4.55 \mathrm{E}-06$ & $1.12 \mathrm{E}-06$ & $1.45 \mathrm{E}-05$ & 0 \\
\hline Eu-154 & $1.46 \mathrm{E}-04$ & 7.29E-05 & $2.01 \mathrm{E}-03$ & $1.38 \mathrm{E}-04$ & $2.37 \mathrm{E}-03$ & $2.23 \mathrm{E}-03$ \\
\hline Sr-90 & $5.19 \mathrm{E}-07$ & $\mathrm{~b}$ & $2.80 \mathrm{E}-07$ & $1.94 \mathrm{E}-06$ & $2.74 \mathrm{E}-06$ & $2.74 \mathrm{E}-06$ \\
\hline \multicolumn{7}{|c|}{ Particle Equivalents } \\
\hline $\mathrm{Ag}-110 \mathrm{~m}$ & $8.03 \mathrm{E}+01$ & $1.23 \mathrm{E}+00$ & $2.93 \mathrm{E}+01$ & $3.23 \mathrm{E}+01$ & $1.43 \mathrm{E}+02$ & 0 \\
\hline Cs-134 & $3.11 \mathrm{E}-01$ & $2.81 \mathrm{E}-02$ & $9.11 \mathrm{E}-02$ & $2.15 \mathrm{E}-02$ & 4.52E-01 & 4.52E-01 \\
\hline Cs-137 & $3.10 \mathrm{E}+00$ & $1.69 \mathrm{E}-02$ & 7.19E-03 & 3.07E-02 & $3.16 \mathrm{E}+00$ & $3.16 \mathrm{E}+00$ \\
\hline Ce-144 & $6.57 \mathrm{E}-02$ & 8.93E-04 & $3.44 \mathrm{E}-02$ & $8.44 \mathrm{E}-03$ & $1.09 \mathrm{E}-01$ & 0 \\
\hline Eu-154 & $1.11 \mathrm{E}+00$ & $5.51 \mathrm{E}-01$ & $1.52 \mathrm{E}+01$ & $1.05 \mathrm{E}+00$ & $1.79 \mathrm{E}+01$ & $1.69 \mathrm{E}+01$ \\
\hline Sr-90 & $3.93 \mathrm{E}-03$ & $\mathrm{~b}$ & $2.12 \mathrm{E}-03$ & $1.47 \mathrm{E}-02$ & $2.08 \mathrm{E}-02$ & $2.08 \mathrm{E}-02$ \\
\hline
\end{tabular}


Table 27. Inventories in capsule rings, hardware (Total of measured + MDA from Table 26), and total inventory measured outside of the fuel ("Grand total measured + MDA" and "Grand total measured only"). Errors are given based on propagation of uncertainty across the sum of all measured values. Shaded cells are based entirely on MDAs or cases where MDAs account for $>50 \%$ of a sum of MDAs and measured values.

\begin{tabular}{|c|c|c|c|c|c|c|c|c|}
\hline Capsule 12 & $\begin{array}{c}\text { Inner } \\
\text { Ring }\end{array}$ & $\begin{array}{c}\text { Outer } \\
\text { Ring }\end{array}$ & $\begin{array}{l}\text { Sink } \\
\text { Ring }\end{array}$ & $\begin{array}{c}\text { Hardware } \\
\text { (measured } \\
+ \text { MDA) } \\
\end{array}$ & $\begin{array}{c}\text { Grand } \\
\text { Total } \\
\text { (measured } \\
+ \text { MDA) }\end{array}$ & $\begin{array}{c}\text { Grand } \\
\text { Total } \\
\text { (measured } \\
\text { only) }\end{array}$ & $\begin{array}{c}\text { Error } \\
\text { (\% minus) } \\
\end{array}$ & $\begin{array}{c}\text { Error } \\
\text { (\% plus) }\end{array}$ \\
\hline $\begin{array}{c}\text { Ring } \\
\text { Material }\end{array}$ & Matrix & PCEA & PCEA & N/A & $\mathrm{N} / \mathrm{A}$ & N/A & N/A & N/A \\
\hline $\begin{array}{c}\text { TAVA } \\
\text { Temp }\left({ }^{\circ} \mathrm{C}\right)\end{array}$ & 782 & 741 & 505 & N/A & N/A & N/A & N/A & $\mathrm{N} / \mathrm{A}$ \\
\hline \multicolumn{9}{|c|}{ Decay-Corrected Activity (Bq) } \\
\hline Ag-110m & $4.07 \mathrm{E}+06$ & $4.43 \mathrm{E}+06$ & $3.19 \mathrm{E}+05$ & $4.31 \mathrm{E}+05$ & $9.25 \mathrm{E}+06$ & 0 & - & - \\
\hline Cs-134 & $1.09 \mathrm{E}+06$ & $7.70 \mathrm{E}+05$ & $4.26 \mathrm{E}+05$ & $2.45 \mathrm{E}+05$ & $2.53 \mathrm{E}+06$ & $1.76 \mathrm{E}+06$ & $6.61 \%$ & $40.29 \%$ \\
\hline Cs-137 & $6.88 \mathrm{E}+06$ & $1.59 \mathrm{E}+05$ & $1.18 \mathrm{E}+07$ & $4.46 \mathrm{E}+06$ & $2.33 \mathrm{E}+07$ & $2.33 \mathrm{E}+07$ & $2.77 \%$ & $3.19 \%$ \\
\hline $\mathrm{Ce}-144$ & $\mathrm{~N} / \mathrm{D}$ & $\mathrm{N} / \mathrm{D}$ & $3.14 \mathrm{E}+06$ & $2.54 \mathrm{E}+06$ & $5.68 \mathrm{E}+06$ & 0 & - & - \\
\hline Eu-154 & $9.58 \mathrm{E}+05$ & $1.24 \mathrm{E}+06$ & $3.25 \mathrm{E}+04$ & $3.28 \mathrm{E}+05$ & $2.56 \mathrm{E}+06$ & $3.09 \mathrm{E}+05$ & $4.93 \%$ & $4.93 \%$ \\
\hline Sr-90 & a & a & $1.55 \mathrm{E}+05$ & $2.74 \mathrm{E}+04$ & $1.82 \mathrm{E}+05$ & $1.82 \mathrm{E}+05$ & $1.62 \%$ & $1.62 \%$ \\
\hline \multicolumn{9}{|c|}{ Capsule Fraction } \\
\hline $\mathrm{Ag}-110 \mathrm{~m}$ & $1.78 \mathrm{E}-01$ & $1.95 \mathrm{E}-01$ & $1.40 \mathrm{E}-02$ & $1.89 \mathrm{E}-02$ & $4.06 \mathrm{E}-01$ & 0 & - & - \\
\hline Cs-134 & $2.66 \mathrm{E}-04$ & $1.88 \mathrm{E}-04$ & $1.04 \mathrm{E}-04$ & $5.97 \mathrm{E}-05$ & $6.18 \mathrm{E}-04$ & $4.30 \mathrm{E}-04$ & $6.61 \%$ & $40.29 \%$ \\
\hline Cs-137 & $6.44 \mathrm{E}-04$ & $1.48 \mathrm{E}-05$ & $1.11 \mathrm{E}-03$ & 4.17E-04 & $2.19 \mathrm{E}-03$ & $2.19 \mathrm{E}-03$ & $2.77 \%$ & $3.19 \%$ \\
\hline $\mathrm{Ce}-144$ & N/D & $\mathrm{N} / \mathrm{D}$ & $1.79 \mathrm{E}-05$ & $1.45 \mathrm{E}-05$ & $3.24 \mathrm{E}-05$ & 0 & - & - \\
\hline $\mathrm{Eu}-154$ & $6.29 \mathrm{E}-03$ & 8.97E-03 & $2.34 \mathrm{E}-04$ & $2.37 \mathrm{E}-03$ & $1.79 \mathrm{E}-02$ & $2.23 \mathrm{E}-03$ & $4.93 \%$ & $4.93 \%$ \\
\hline Sr-90 & a & a & $1.55 \mathrm{E}-05$ & $2.74 \mathrm{E}-06$ & $1.83 \mathrm{E}-05$ & $1.83 \mathrm{E}-05$ & $1.62 \%$ & $1.62 \%$ \\
\hline \multicolumn{9}{|c|}{ Particle Equivalents } \\
\hline $\mathrm{Ag}-110 \mathrm{~m}$ & $1.35 \mathrm{E}+03$ & $1.48 \mathrm{E}+03$ & $1.06 \mathrm{E}+02$ & $1.43 \mathrm{E}+02$ & $3.07 \mathrm{E}+03$ & 0 & - & - \\
\hline Cs-134 & $2.01 \mathrm{E}+00$ & $1.42 \mathrm{E}+00$ & $7.87 \mathrm{E}-01$ & $4.52 \mathrm{E}-01$ & $4.67 \mathrm{E}+00$ & $3.25 \mathrm{E}+00$ & $6.61 \%$ & $40.29 \%$ \\
\hline Cs-137 & $4.87 \mathrm{E}+00$ & $1.12 \mathrm{E}-01$ & $8.39 \mathrm{E}+00$ & $3.16 \mathrm{E}+00$ & $1.65 \mathrm{E}+01$ & $1.65 \mathrm{E}+01$ & $2.77 \%$ & $3.19 \%$ \\
\hline $\mathrm{Ce}-144$ & N/D & $\mathrm{N} / \mathrm{D}$ & $1.35 \mathrm{E}-01$ & $1.09 \mathrm{E}-01$ & $2.45 \mathrm{E}-01$ & 0 & - & - \\
\hline Eu-154 & $4.76 \mathrm{E}+01$ & $6.79 \mathrm{E}+01$ & $1.77 \mathrm{E}+00$ & $1.79 \mathrm{E}+01$ & $1.35 \mathrm{E}+02$ & $1.69 \mathrm{E}+01$ & $4.93 \%$ & $4.93 \%$ \\
\hline Sr-90 & $\mathrm{a}$ & a & $1.17 \mathrm{E}-01$ & $2.08 \mathrm{E}-02$ & $1.38 \mathrm{E}-01$ & $1.38 \mathrm{E}-01$ & $1.62 \%$ & $1.62 \%$ \\
\hline \multicolumn{9}{|c|}{$\begin{array}{ll}\text { N/A } & \text { not applicable. } \\
\text { N/D } & \text { not detected on PGS. MDA not determined. } \\
\text { a. } & \text { requires destructive analysis to measure. }\end{array}$} \\
\hline
\end{tabular}




\subsection{Summary of Capsule Fission Products Outside of the Fuel}

Table 28 summarizes the total fraction of major fission products measured outside of the fuel for each capsule. Table 29 summarizes the total inventory of fission products outside of the fuel expressed in terms of the number of particle equivalents. One particle equivalent is equal to a capsule fraction of $1.32 \mathrm{E}-4$. Since each capsule had 80 DTF particles, the DTF particles equate to a capsule fraction of $1.06 \mathrm{E}-2$. The relative measurement errors for each value in Table 28 and Table 29 are summarized in Table 30. In Table 28 and Table 29, there are "high" and "low" values for each isotope in each capsule. The "low" values are from summing only measured values across all measured components. The "high" values are from summing the measured values across all measured components, and when an isotope was not detected, an MDA was determined, converted into a decay-corrected fraction, and added to the measured (detected) values. In cases where fractions derived from MDAs account for $>50 \%$ of the sum, the cell is shaded.

There are several cases where the mass balance of a particular isotope is not complete. Recall that Capsules 2, 6, 9, and 11 were fuel bodies that were retained intact for future study; thus, the inventories of the inner and outer rings in these capsules have not been determined. Accordingly, the mass balance for these capsules is incomplete until the rings are analyzed. Additionally, burn-leach analysis is required to measure Sr-90 in inner and outer rings. The Sr-90 column does not contain Sr-90 inventories from any inner or outer ring. Physical sampling and burn-leach analysis has been completed on the inner and outer rings from Capsules 3 and 7. A Sr-90 inventory for these ring could be extrapolated from the sampling results and used as an estimate of the Sr-90 inventory. Values for Ce-144, Eu-155, and Ru-106 were not reported from PGS scans of the inner and outer rings. Thus the mass balance for those isotopes is incomplete, and the errors reported for those isotopes in Table 30 will not have a contribution from PGS measurement error. No foils or felts were recovered from Capsule 4. No spacers were recovered from Capsule 5, and only one spacer was recovered from Capsule 7. These un-recovered components could have significant fission product inventories.

In a number of cases in the tables below, there are significant differences between the "high" and "low" values. This is due to the fact that these sums are across many different capsule components that were analyzed using different methods. For example, the through-tubes for each capsule were leached and the leachate gamma counted at detectors outside of the AL hot cells; the sink rings were gamma counted using the rotating sample holder at the Hot Cell 4 spectrometer; the foils and spacers were counted using the stationary sample holder for the Hot Cell 4 spectrometer; most felts were counted on the HOGS, but the Capsule 7 and 10 felts were counted at AL; the inner and outer rings were counted on the PGS. Each technique, sample type (geometry), and location has different MDAs and backgrounds that contribute to the uncertainty in the true inventory.

Table 28. Summary of total fission product fractions outside of the fuel in each capsule. "Low" includes measured values only. "High" represents measured values plus fractions calculated from MDAs.

\begin{tabular}{|c|c|c|c|c|c|c|c|c|c|}
\hline \multicolumn{2}{|c|}{ Fractions } & Ag-110m & Ce-144 & Cs-134 & Cs-137 & Eu-154 & Eu-155 & Ru-106 & Sr-90 $^{\mathbf{b}}$ \\
\hline \multirow{2}{*}{1} & Low & $2.94 \mathrm{E}-3$ & $0.00 \mathrm{E}+0$ & $6.75 \mathrm{E}-4$ & $1.26 \mathrm{E}-3$ & $1.07 \mathrm{E}-3$ & $1.69 \mathrm{E}-3$ & $0.00 \mathrm{E}+0$ & $4.64 \mathrm{E}-6$ \\
\cline { 2 - 10 } & High & $1.23 \mathrm{E}-1$ & $2.04 \mathrm{E}-5$ & $6.80 \mathrm{E}-4$ & $1.26 \mathrm{E}-3$ & $5.98 \mathrm{E}-3$ & $1.82 \mathrm{E}-3$ & $1.07 \mathrm{E}-4$ & $4.64 \mathrm{E}-6$ \\
\hline \multirow{2}{*}{$2^{\mathrm{a}}$} & Low & $0.00 \mathrm{E}+0$ & $0.00 \mathrm{E}+0$ & $5.52 \mathrm{E}-4$ & $1.26 \mathrm{E}-3$ & $0.00 \mathrm{E}+0$ & $1.31 \mathrm{E}-3$ & $0.00 \mathrm{E}+0$ & $7.37 \mathrm{E}-6$ \\
\cline { 2 - 10 } & High & $6.47 \mathrm{E}-3$ & $1.94 \mathrm{E}-5$ & $5.52 \mathrm{E}-4$ & $1.26 \mathrm{E}-3$ & $1.40 \mathrm{E}-4$ & $1.74 \mathrm{E}-3$ & $7.53 \mathrm{E}-5$ & $7.37 \mathrm{E}-6$ \\
\hline \multirow{2}{*}{3} & Low & $6.93 \mathrm{E}-1$ & $7.32 \mathrm{E}-6$ & $4.74 \mathrm{E}-3$ & $5.42 \mathrm{E}-3$ & $4.67 \mathrm{E}-3$ & $1.66 \mathrm{E}-3$ & $0.00 \mathrm{E}+0$ & $3.08 \mathrm{E}-4$ \\
\cline { 2 - 10 } & High & $6.95 \mathrm{E}-1$ & $2.94 \mathrm{E}-5$ & $4.74 \mathrm{E}-3$ & $5.42 \mathrm{E}-3$ & $5.93 \mathrm{E}-3$ & $2.08 \mathrm{E}-3$ & $8.66 \mathrm{E}-5$ & $3.08 \mathrm{E}-4$ \\
\hline \multirow{2}{*}{4} & Low & $7.40 \mathrm{E}-2$ & $0.00 \mathrm{E}+0$ & $9.52 \mathrm{E}-3$ & $9.68 \mathrm{E}-3$ & $0.00 \mathrm{E}+0$ & $2.48 \mathrm{E}-3$ & $0.00 \mathrm{E}+0$ & $1.02 \mathrm{E}-5$ \\
\cline { 2 - 10 } & High & $7.49 \mathrm{E}-2$ & $3.08 \mathrm{E}-5$ & $9.52 \mathrm{E}-3$ & $9.68 \mathrm{E}-3$ & $1.90 \mathrm{E}-3$ & $2.53 \mathrm{E}-3$ & $2.75 \mathrm{E}-5$ & $1.02 \mathrm{E}-5$ \\
\hline
\end{tabular}




\begin{tabular}{|c|c|c|c|c|c|c|c|c|c|}
\hline \multicolumn{2}{|c|}{ Fractions } & Ag-110m & Ce-144 & Cs-134 & Cs-137 & Eu-154 & Eu-155 & Ru-106 & Sr-90 ${ }^{b}$ \\
\hline \multirow[t]{2}{*}{5} & Low & $4.44 \mathrm{E}-3$ & $1.15 \mathrm{E}-5$ & $8.38 \mathrm{E}-3$ & $8.00 \mathrm{E}-3$ & $0.00 \mathrm{E}+0$ & $0.00 \mathrm{E}+0$ & $0.00 \mathrm{E}+0$ & 4.64E-6 \\
\hline & High & $6.12 \mathrm{E}-3$ & $2.46 \mathrm{E}-5$ & $8.38 \mathrm{E}-3$ & $8.00 \mathrm{E}-3$ & $1.68 \mathrm{E}-3$ & 4.01E-4 & $4.29 \mathrm{E}-5$ & 4.64E-6 \\
\hline \multirow[t]{2}{*}{$6^{\mathrm{a}}$} & Low & $1.70 \mathrm{E}-3$ & $0.00 \mathrm{E}+0$ & 4.33E-4 & $6.27 \mathrm{E}-4$ & $3.08 \mathrm{E}-7$ & $0.00 \mathrm{E}+0$ & $0.00 \mathrm{E}+0$ & $3.39 \mathrm{E}-6$ \\
\hline & High & $4.58 \mathrm{E}-3$ & $2.58 \mathrm{E}-5$ & $4.34 \mathrm{E}-4$ & $6.27 \mathrm{E}-4$ & $8.55 \mathrm{E}-5$ & $4.51 \mathrm{E}-4$ & $6.26 \mathrm{E}-5$ & $3.39 \mathrm{E}-6$ \\
\hline \multirow[t]{2}{*}{7} & Low & $1.01 \mathrm{E}+0$ & $0.00 \mathrm{E}+0$ & $5.98 \mathrm{E}-3$ & $6.56 \mathrm{E}-3$ & $3.08 \mathrm{E}-2$ & $5.51 \mathrm{E}-4$ & $0.00 \mathrm{E}+0$ & 4.40E-4 \\
\hline & High & $1.01 \mathrm{E}+0$ & $1.45 \mathrm{E}-5$ & $5.98 \mathrm{E}-3$ & $6.56 \mathrm{E}-3$ & 3.17E-2 & 8.61E-4 & $5.06 \mathrm{E}-5$ & 4.40E-4 \\
\hline \multirow[t]{2}{*}{8} & Low & $8.82 \mathrm{E}-1$ & $2.24 \mathrm{E}-6$ & $6.92 \mathrm{E}-3$ & 7.95E-3 & $1.46 \mathrm{E}-3$ & 3.92E-4 & $2.79 \mathrm{E}-6$ & $9.37 \mathrm{E}-5$ \\
\hline & High & $8.82 \mathrm{E}-1$ & $1.75 \mathrm{E}-5$ & $6.92 \mathrm{E}-3$ & 7.95E-3 & $2.53 \mathrm{E}-3$ & 7.75E-4 & $4.51 \mathrm{E}-5$ & 9.37E-5 \\
\hline \multirow[t]{2}{*}{$9^{a}$} & Low & $4.15 \mathrm{E}-3$ & $0.00 \mathrm{E}+0$ & 2.91E-4 & $6.70 \mathrm{E}-4$ & 2.93E-4 & $1.38 \mathrm{E}-3$ & $1.90 \mathrm{E}-6$ & $4.70 \mathrm{E}-6$ \\
\hline & High & $8.49 \mathrm{E}-3$ & $2.42 \mathrm{E}-5$ & 2.91E-4 & $6.70 \mathrm{E}-4$ & $5.00 \mathrm{E}-4$ & $1.50 \mathrm{E}-3$ & $1.25 \mathrm{E}-4$ & $4.70 \mathrm{E}-6$ \\
\hline \multirow[t]{2}{*}{10} & Low & $7.29 \mathrm{E}-1$ & $9.91 \mathrm{E}-7$ & $5.74 \mathrm{E}-3$ & $6.65 \mathrm{E}-3$ & $1.21 \mathrm{E}-3$ & $6.09 \mathrm{E}-4$ & $3.22 \mathrm{E}-6$ & $2.78 \mathrm{E}-4$ \\
\hline & High & $7.30 \mathrm{E}-1$ & $1.74 \mathrm{E}-5$ & $5.74 \mathrm{E}-3$ & $6.65 \mathrm{E}-3$ & $1.32 \mathrm{E}-3$ & $9.96 \mathrm{E}-4$ & $5.43 \mathrm{E}-5$ & $2.78 \mathrm{E}-4$ \\
\hline \multirow[t]{2}{*}{$11^{\mathrm{a}}$} & Low & $5.44 \mathrm{E}-2$ & $1.16 \mathrm{E}-6$ & $3.50 \mathrm{E}-3$ & $4.21 \mathrm{E}-3$ & $2.63 \mathrm{E}-3$ & $3.02 \mathrm{E}-3$ & $0.00 \mathrm{E}+0$ & $1.51 \mathrm{E}-5$ \\
\hline & High & $2.86 \mathrm{E}-1$ & $3.33 \mathrm{E}-5$ & $3.50 \mathrm{E}-3$ & $4.21 \mathrm{E}-3$ & $2.85 \mathrm{E}-3$ & $3.12 \mathrm{E}-3$ & $1.00 \mathrm{E}-4$ & $1.51 \mathrm{E}-5$ \\
\hline \multirow[t]{2}{*}{12} & Low & $0.00 \mathrm{E}+0$ & $0.00 \mathrm{E}+0$ & 4.30E-4 & $2.19 \mathrm{E}-3$ & $2.23 \mathrm{E}-3$ & 7.41E-4 & $8.20 \mathrm{E}-8$ & $1.83 \mathrm{E}-5$ \\
\hline & High & $4.06 \mathrm{E}-1$ & $3.23 \mathrm{E}-5$ & $6.18 \mathrm{E}-4$ & 2.19E-3 & $1.79 \mathrm{E}-2$ & $1.56 \mathrm{E}-03$ & $1.87 \mathrm{E}-4$ & $1.83 \mathrm{E}-5$ \\
\hline
\end{tabular}

Table 29. Summary of the fission product inventory measured outside of the fuel expressed units of particle equivalents. "Low" includes measured values only. "High" represents measured values plus particle equivalents calculated from MDAs.

\begin{tabular}{|c|c|c|c|c|c|c|c|c|c|}
\hline \multicolumn{2}{|c|}{$\begin{array}{c}\text { Particle } \\
\text { Equivalents }\end{array}$} & Ag-110m & Ce-144 & Cs-134 & Cs-137 & Eu-154 & Eu-155 & Ru-106 & Sr-90 $^{\mathbf{b}}$ \\
\hline \multirow{2}{*}{1} & Low & $2.23 \mathrm{E}+1$ & $0.00 \mathrm{E}+0$ & $5.11 \mathrm{E}+0$ & $9.53 \mathrm{E}+0$ & $8.10 \mathrm{E}+0$ & $1.28 \mathrm{E}+1$ & $0.00 \mathrm{E}+0$ & $3.51 \mathrm{E}-2$ \\
\cline { 2 - 11 } & High & $9.33 \mathrm{E}+2$ & $1.55 \mathrm{E}-1$ & $5.14 \mathrm{E}+0$ & $9.53 \mathrm{E}+0$ & $4.53 \mathrm{E}+1$ & $1.38 \mathrm{E}+1$ & $8.10 \mathrm{E}-1$ & $3.51 \mathrm{E}-2$ \\
\hline \multirow{2}{*}{$2^{\mathrm{a}}$} & Low & $0.00 \mathrm{E}+0$ & $0.00 \mathrm{E}+0$ & $4.18 \mathrm{E}+0$ & $9.55 \mathrm{E}+0$ & $0.00 \mathrm{E}+0$ & $9.91 \mathrm{E}+0$ & $0.00 \mathrm{E}+0$ & $5.58 \mathrm{E}-2$ \\
\cline { 2 - 11 } & High & $4.90 \mathrm{E}+1$ & $1.47 \mathrm{E}-1$ & $4.18 \mathrm{E}+0$ & $9.55 \mathrm{E}+0$ & $1.06 \mathrm{E}+0$ & $1.32 \mathrm{E}+1$ & $5.70 \mathrm{E}-1$ & $5.58 \mathrm{E}-2$ \\
\hline \multirow{3}{*}{3} & Low & $5.25 \mathrm{E}+3$ & $5.54 \mathrm{E}-2$ & $3.59 \mathrm{E}+1$ & $4.11 \mathrm{E}+1$ & $3.53 \mathrm{E}+1$ & $1.26 \mathrm{E}+1$ & $0.00 \mathrm{E}+0$ & $2.33 \mathrm{E}+0$ \\
\cline { 2 - 11 } & High & $5.26 \mathrm{E}+3$ & $2.23 \mathrm{E}-1$ & $3.59 \mathrm{E}+1$ & $4.11 \mathrm{E}+1$ & $4.49 \mathrm{E}+1$ & $1.58 \mathrm{E}+1$ & $6.55 \mathrm{E}-1$ & $2.33 \mathrm{E}+0$ \\
\hline \multirow{3}{*}{4} & Low & $5.60 \mathrm{E}+2$ & $0.00 \mathrm{E}+0$ & $7.21 \mathrm{E}+1$ & $7.32 \mathrm{E}+1$ & $0.00 \mathrm{E}+0$ & $1.88 \mathrm{E}+1$ & $0.00 \mathrm{E}+0$ & $7.75 \mathrm{E}-2$ \\
\cline { 2 - 11 } & High & $5.67 \mathrm{E}+2$ & $2.33 \mathrm{E}-1$ & $7.21 \mathrm{E}+1$ & $7.32 \mathrm{E}+1$ & $1.44 \mathrm{E}+1$ & $1.92 \mathrm{E}+1$ & $2.08 \mathrm{E}-1$ & $7.75 \mathrm{E}-2$ \\
\hline \multirow{2}{*}{5} & Low & $3.36 \mathrm{E}+1$ & $8.69 \mathrm{E}-2$ & $6.34 \mathrm{E}+1$ & $6.05 \mathrm{E}+1$ & $0.00 \mathrm{E}+0$ & $0.00 \mathrm{E}+0$ & $0.00 \mathrm{E}+0$ & $3.51 \mathrm{E}-2$ \\
\cline { 2 - 11 } & High & $4.63 \mathrm{E}+1$ & $1.86 \mathrm{E}-1$ & $6.34 \mathrm{E}+1$ & $6.05 \mathrm{E}+1$ & $1.27 \mathrm{E}+1$ & $3.03 \mathrm{E}+0$ & $3.25 \mathrm{E}-1$ & $3.51 \mathrm{E}-2$ \\
\hline \multirow{2}{*}{$6^{\mathrm{a}}$} & Low & $1.29 \mathrm{E}+1$ & $0.00 \mathrm{E}+0$ & $3.28 \mathrm{E}+0$ & $4.74 \mathrm{E}+0$ & $2.33 \mathrm{E}-3$ & $0.00 \mathrm{E}+0$ & $0.00 \mathrm{E}+0$ & $2.57 \mathrm{E}-2$ \\
\cline { 2 - 10 } & High & $3.47 \mathrm{E}+1$ & $1.95 \mathrm{E}-1$ & $3.29 \mathrm{E}+0$ & $4.74 \mathrm{E}+0$ & $6.47 \mathrm{E}-1$ & $3.41 \mathrm{E}+0$ & $4.74 \mathrm{E}-1$ & $2.57 \mathrm{E}-2$ \\
\hline \multirow{2}{*}{7} & Low & $7.65 \mathrm{E}+3$ & $0.00 \mathrm{E}+0$ & $4.52 \mathrm{E}+1$ & $4.96 \mathrm{E}+1$ & $2.33 \mathrm{E}+2$ & $4.17 \mathrm{E}+0$ & $7.75 \mathrm{E}-3$ & $3.33 \mathrm{E}+0$ \\
\hline
\end{tabular}




\begin{tabular}{|c|c|c|c|c|c|c|c|c|c|}
\hline \multicolumn{2}{|c|}{$\begin{array}{c}\text { Particle } \\
\text { Equivalents }\end{array}$} & \multirow{2}{*}{$\frac{\text { Ag-110m }}{7.65 \mathrm{E}+3}$} & \multirow{2}{*}{$\begin{array}{l}\text { Ce-144 } \\
1.10 \mathrm{E}-1\end{array}$} & \multirow{2}{*}{$\begin{array}{l}\text { Cs-134 } \\
4.52 \mathrm{E}+1 \\
\end{array}$} & \multirow{2}{*}{$\begin{array}{l}\text { Cs-137 } \\
4.96 \mathrm{E}+1\end{array}$} & \multirow{2}{*}{$\begin{array}{c}\text { Eu-154 } \\
2.40 \mathrm{E}+2 \\
\end{array}$} & \multirow{2}{*}{$\begin{array}{l}\text { Eu-155 } \\
6.52 \mathrm{E}+0 \\
\end{array}$} & \multirow{2}{*}{$\begin{array}{l}\text { Ru-106 } \\
3.83 \mathrm{E}-1 \\
\end{array}$} & \multirow{2}{*}{$\frac{\mathbf{S r}^{-90^{\mathbf{b}}}}{3.33 \mathrm{E}+0}$} \\
\hline & High & & & & & & & & \\
\hline \multirow{2}{*}{8} & Low & $6.67 \mathrm{E}+3$ & $1.69 \mathrm{E}-2$ & $5.23 \mathrm{E}+1$ & $6.02 \mathrm{E}+1$ & $1.11 \mathrm{E}+1$ & $2.96 \mathrm{E}+0$ & $2.11 \mathrm{E}-2$ & 7.09E-1 \\
\hline & High & $6.68 \mathrm{E}+3$ & $1.32 \mathrm{E}-1$ & $5.23 \mathrm{E}+1$ & $6.02 \mathrm{E}+1$ & $1.92 \mathrm{E}+1$ & $5.87 \mathrm{E}+0$ & $3.41 \mathrm{E}-1$ & $7.09 \mathrm{E}-1$ \\
\hline \multirow{2}{*}{$9^{a}$} & Low & $3.14 \mathrm{E}+1$ & $0.00 \mathrm{E}+0$ & $2.20 \mathrm{E}+0$ & $5.07 \mathrm{E}+0$ & $2.22 \mathrm{E}+0$ & $1.05 \mathrm{E}+1$ & $1.43 \mathrm{E}-2$ & $3.56 \mathrm{E}-2$ \\
\hline & High & $6.43 \mathrm{E}+1$ & $1.83 \mathrm{E}-1$ & $2.20 \mathrm{E}+0$ & $5.07 \mathrm{E}+0$ & $3.78 \mathrm{E}+0$ & $1.14 \mathrm{E}+1$ & $9.48 \mathrm{E}-1$ & $3.56 \mathrm{E}-2$ \\
\hline \multirow{2}{*}{10} & Low & $5.52 \mathrm{E}+3$ & $7.50 \mathrm{E}-3$ & $4.34 \mathrm{E}+1$ & $5.03 \mathrm{E}+1$ & $9.15 \mathrm{E}+0$ & $4.61 \mathrm{E}+0$ & $2.44 \mathrm{E}-2$ & $2.10 \mathrm{E}+0$ \\
\hline & High & $5.52 \mathrm{E}+3$ & $1.32 \mathrm{E}-1$ & $4.34 \mathrm{E}+1$ & $5.03 \mathrm{E}+1$ & $9.96 \mathrm{E}+0$ & $7.54 \mathrm{E}+0$ & $4.11 \mathrm{E}-1$ & $2.10 \mathrm{E}+0$ \\
\hline \multirow{2}{*}{$11^{\mathrm{a}}$} & Low & $4.12 \mathrm{E}+2$ & $8.81 \mathrm{E}-3$ & $2.65 \mathrm{E}+1$ & $3.18 \mathrm{E}+1$ & $1.99 \mathrm{E}+1$ & $2.28 \mathrm{E}+1$ & $0.00 \mathrm{E}+0$ & $1.14 \mathrm{E}-1$ \\
\hline & High & $2.17 \mathrm{E}+3$ & $2.52 \mathrm{E}-1$ & $2.65 \mathrm{E}+1$ & $3.18 \mathrm{E}+1$ & $2.16 \mathrm{E}+1$ & $2.36 \mathrm{E}+1$ & $7.59 \mathrm{E}-1$ & $1.14 \mathrm{E}-1$ \\
\hline \multirow{2}{*}{12} & Low & $0.00 \mathrm{E}+0$ & $0.00 \mathrm{E}+0$ & $3.25 \mathrm{E}+0$ & $1.65 \mathrm{E}+1$ & $1.69 \mathrm{E}+1$ & $5.61 \mathrm{E}+0$ & $6.21 \mathrm{E}-4$ & $1.38 \mathrm{E}-1$ \\
\hline & High & $3.07 \mathrm{E}+3$ & $2.45 \mathrm{E}-1$ & $4.67 \mathrm{E}+0$ & $1.65 \mathrm{E}+1$ & $1.35 \mathrm{E}+2$ & $1.18 \mathrm{E}+1$ & $1.41 \mathrm{E}+0$ & $1.38 \mathrm{E}-1$ \\
\hline
\end{tabular}

Table 30. Total percent error (+/-) of the total measured fraction of fission products outside of the fuel (corresponding to the "low" rows in Table 28 and Table 29). Blank cells indicate no activity was measured.

\begin{tabular}{|c|c|c|c|c|c|c|c|c|c|}
\hline \multirow{2}{*}{\multicolumn{2}{|c|}{ Frner }} & \multirow{3}{*}{$\begin{array}{c}\mathbf{A g - 1 1 0 m} \\
7.4 \% \\
\end{array}$} & \multirow{3}{*}{$\frac{\mathrm{Ce}-144}{-}$} & \multirow{3}{*}{$\begin{array}{c}\text { Cs-134 } \\
3.9 \% \\
\end{array}$} & \multirow{3}{*}{$\begin{array}{c}\text { Cs-137 } \\
2.0 \% \\
\end{array}$} & \multirow{3}{*}{$\begin{array}{c}\text { Eu-154 } \\
23.7 \% \\
\end{array}$} & \multirow{3}{*}{$\begin{array}{c}\text { Eu-155 } \\
4.7 \% \\
\end{array}$} & & \\
\hline & rror & & & & & & & \multirow{2}{*}{$\begin{array}{c}\text { Ru-106 } \\
-\end{array}$} & \multirow{2}{*}{$\begin{array}{r}\text { Sr-90 } \\
3.2 \% \\
\end{array}$} \\
\hline & minus & & & & & & & & \\
\hline 1 & plus & $7.4 \%$ & - & $20.1 \%$ & $2.6 \%$ & $469.8 \%$ & $4.7 \%$ & - & $3.2 \%$ \\
\hline \multirow{2}{*}{2} & minus & - & - & $4.1 \%$ & $4.1 \%$ & - & $5.0 \%$ & - & $1.7 \%$ \\
\hline & plus & - & - & $4.1 \%$ & $4.1 \%$ & - & $5.0 \%$ & - & $1.7 \%$ \\
\hline \multirow{2}{*}{3} & minus & $4.1 \%$ & $19.8 \%$ & $3.7 \%$ & $3.3 \%$ & $4.5 \%$ & $4.2 \%$ & - & $1.1 \%$ \\
\hline & plus & $4.1 \%$ & $19.8 \%$ & $3.7 \%$ & $3.3 \%$ & $9.2 \%$ & $4.2 \%$ & - & $1.1 \%$ \\
\hline \multirow{2}{*}{4} & minus & $4.0 \%$ & - & $0.3 \%$ & $0.4 \%$ & - & $6.4 \%$ & - & $1.7 \%$ \\
\hline & plus & $18.6 \%$ & - & $0.3 \%$ & $0.4 \%$ & - & $6.4 \%$ & - & $1.7 \%$ \\
\hline \multirow{2}{*}{5} & minus & $9.8 \%$ & $17.8 \%$ & $0.4 \%$ & $0.4 \%$ & - & - & - & $1.6 \%$ \\
\hline & plus & $238.8 \%$ & $17.8 \%$ & $0.4 \%$ & $0.5 \%$ & - & - & - & $1.6 \%$ \\
\hline \multirow{2}{*}{6} & minus & $4.0 \%$ & - & $3.7 \%$ & $3.7 \%$ & $27.6 \%$ & - & - & $3.0 \%$ \\
\hline & plus & $4.0 \%$ & - & $3.7 \%$ & $3.7 \%$ & $27.6 \%$ & - & - & $3.0 \%$ \\
\hline \multirow{2}{*}{7} & minus & $4.8 \%$ & - & $3.1 \%$ & $3.0 \%$ & $1.1 \%$ & $4.7 \%$ & - & $1.1 \%$ \\
\hline & plus & $4.8 \%$ & - & $3.1 \%$ & $3.0 \%$ & $1.4 \%$ & $4.7 \%$ & - & $1.1 \%$ \\
\hline \multirow{2}{*}{8} & minus & $0.8 \%$ & $15.6 \%$ & $2.2 \%$ & $2.0 \%$ & $7.1 \%$ & $4.8 \%$ & $20.0 \%$ & $1.0 \%$ \\
\hline & plus & $1.0 \%$ & $15.6 \%$ & $2.2 \%$ & $2.0 \%$ & $66.7 \%$ & $4.8 \%$ & $20.0 \%$ & $1.0 \%$ \\
\hline \multirow{2}{*}{9} & minus & $1.5 \%$ & - & $4.0 \%$ & $3.7 \%$ & $3.0 \%$ & $10.6 \%$ & $0.5 \%$ & $1.5 \%$ \\
\hline & plus & $1.5 \%$ & - & $4.0 \%$ & $3.7 \%$ & $3.0 \%$ & $10.6 \%$ & $0.5 \%$ & $1.5 \%$ \\
\hline 10 & minus & $1.9 \%$ & $29.0 \%$ & $3.0 \%$ & $2.8 \%$ & $8.8 \%$ & $4.2 \%$ & $15.3 \%$ & $3.4 \%$ \\
\hline
\end{tabular}




\begin{tabular}{|c|c|c|c|c|c|c|c|c|c|}
\hline \multicolumn{2}{|c|}{ Error } & Ag-110m & Ce-144 & Cs-134 & Cs-137 & Eu-154 & Eu-155 & Ru-106 & Sr-90 \\
\hline & plus & $2.1 \%$ & $29.0 \%$ & $3.0 \%$ & $2.8 \%$ & $98.5 \%$ & $4.2 \%$ & $15.3 \%$ & $3.4 \%$ \\
\hline \multirow{2}{*}{11} & minus & $5.8 \%$ & $15.0 \%$ & $4.5 \%$ & $4.5 \%$ & $4.5 \%$ & $4.2 \%$ & - & $1.5 \%$ \\
\cline { 2 - 10 } & plus & $5.8 \%$ & $15.0 \%$ & $4.5 \%$ & $4.5 \%$ & $4.5 \%$ & $4.2 \%$ & - & $1.5 \%$ \\
\hline \multirow{2}{*}{12} & minus & - & - & $6.6 \%$ & $2.8 \%$ & $4.9 \%$ & $10.4 \%$ & $29.4 \%$ & $1.6 \%$ \\
\cline { 2 - 10 } & plus & - & $40.3 \%$ & $3.2 \%$ & $4.9 \%$ & $10.4 \%$ & $29.4 \%$ & $1.6 \%$ \\
\hline
\end{tabular}

\section{DISCUSSION}

The AGR-1 and AGR-2 experiments focused on studying fuel performance to answer the questions: how well do the TRISO coatings perform, and how well does high-quality fuel retain fission products under normal operation and high-temperature accident conditions? AGR-3/4 was an experiment primarily aimed at studying fission product transport with imperfect fuel, hence the incorporation of $80 \mathrm{DTF}$ particles into each capsule. It was thought that prior to failure of the DTF pyrocarbon coating, DTF particles would behave like a TRISO fuel particle with a failed SiC layer, releasing substantial metallic fission products (especially cesium), but retaining fission gases. Once the DTF pyrocarbon coating failed, it was expected that the fission gases would also escape.

\subsection{Rings Inventory Comparison}

Figure 10 through Figure 12 summarize the fraction of the capsule inventory of Ag-110m, Cs-134, and Eu-154 measured in the inner, outer, and sink rings for each capsule. Figure 10 shows that in every ring with Ag-110m levels above the MDA, greater than one particle worth of Ag-110m was present. Inner rings had Ag-110m inventories ranging from slightly greater than 2 particle equivalents (a fraction of $2.8 \mathrm{E}-4)$ up to a fraction $<0.178(<1348.5$ particles based on the MDA). Four of the outer rings had higher Ag-110m inventories than their respective inner rings. The sink rings from Capsules 3, 7, 8, 10, and 11 had between $4 \%$ and $98 \%$ of all of the Ag- $110 \mathrm{~m}$ produced in those capsules, indicating that significant radial transport of Ag through the rings had occurred. In many rings, the Ag-110m fraction exceeded the fraction of DTF particles, indicating that driver particles were releasing significant Ag-110m through intact TRISO coatings. In Capsules 1 and 12, detecting Ag-110m was difficult because the low burnup of these capsules ( $<7.0 \%$ FIMA) meant that little Ag- $110 \mathrm{~m}$ was produced compared to the other capsules (up to 34 times less $\mathrm{Ag}-110 \mathrm{~m}$ ), and the low temperatures of Capsules 1 and 12 meant that less silver was driven from the fuel into the surrounding rings.

Figure 11 shows that Cs-134 was detected in each ring for all capsules analyzed except for Capsule 12. In some capsules (i.e., 1, 4, and 5), the Cs-134 fraction decreases from the inner ring, to the outer ring, to the sink ring. In other capsules (i.e., 7, 8, and 10), the Cs-134 fraction increases from the inner ring through to the sink ring. In Capsule 3, the fraction of Cs-134 in the inner and outer rings is similar, and is highest in the sink ring. In all cases, the total fraction (the sum of the inner, outer, and sink ring inventories) of Cs-134 in the rings was less than the fraction of DTF particles in each capsule. Cs-137 was also measured as part of the analysis, but Cs-134 results are presented here as they are less susceptible to biases due to hot cell contamination. 


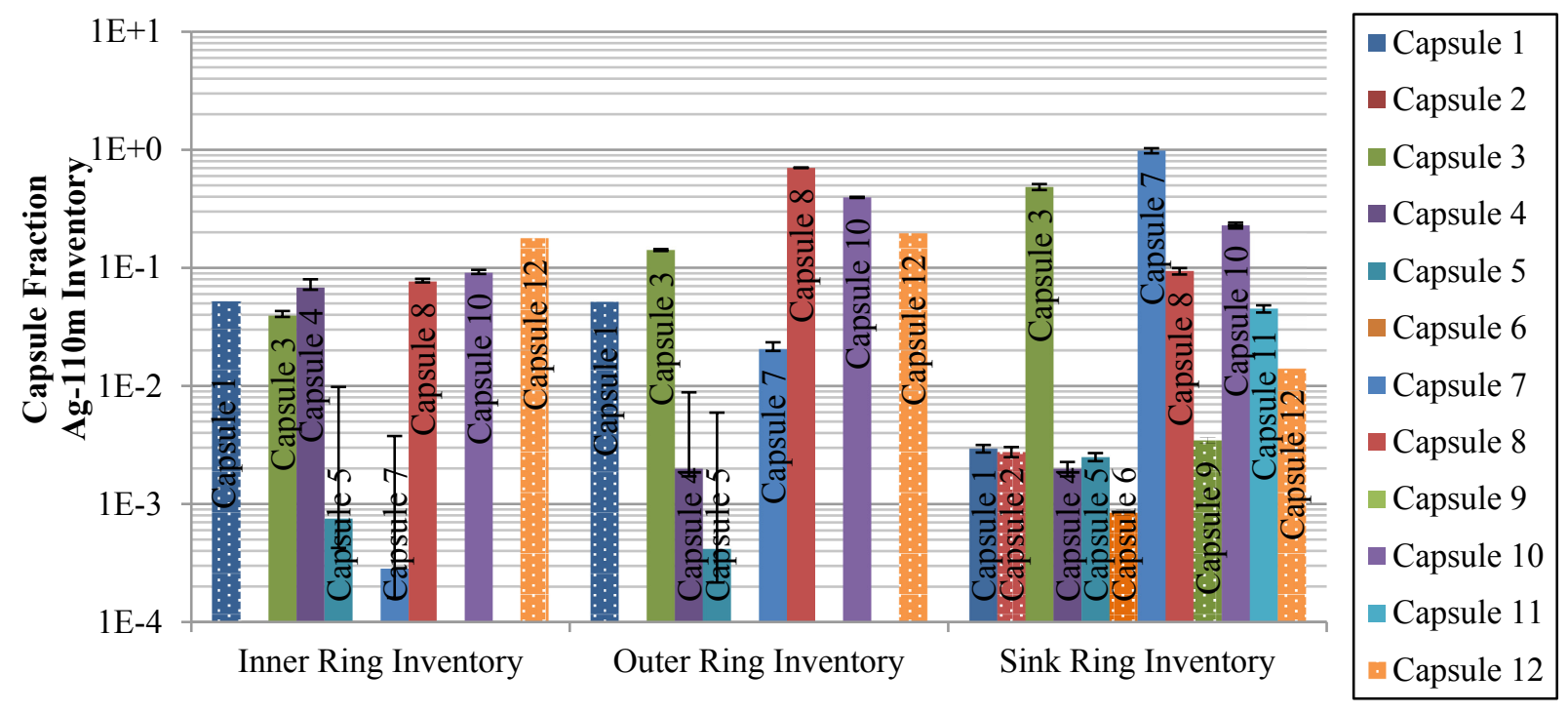

Figure 10. Inner, outer, and sink ring Ag-110m capsule fractions. Bars with patterned fill are based on MDAs.

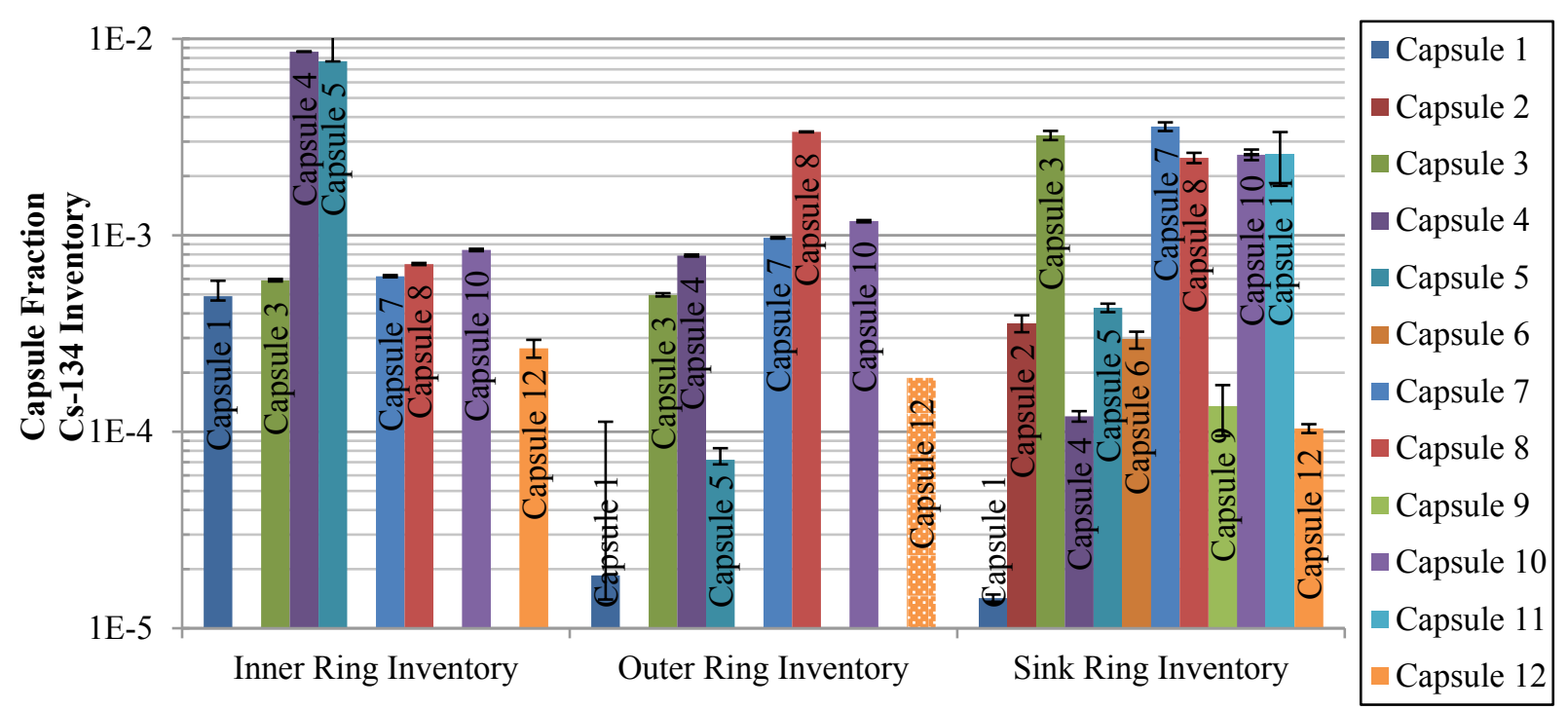

Figure 11. Inner, outer, and sink ring Cs-134 capsule fractions. The bar with patterned fill is based on an MDA.

Figure 12 summarizes the Eu-154 inventories in the rings. Eu-154 was detected in 5 of the 8 inner rings that were counted. Only the Capsule 10 outer ring had a detectable Eu-154 inventory. Eu-154 was not detected in any of the sink rings, thus values derived from MDAs have been plotted for the sink rings. Capsules 3, 7, 8, and 10 were the hottest standard capsules in the test, which would have contributed to mobilize Eu-154 from the compacts to the inner rings. Capsule 7 fuel compacts had the highest TAVA irradiation temperatures of any fuel to date in the AGR program. Averaged over the four Capsule 7 compacts, the TAVA was $1345^{\circ} \mathrm{C}$ (see Figure 4), but individual compacts had TAVA temperatures ranging from 1311 to $1376^{\circ} \mathrm{C}$ (see Figure 5). Each of the bars for the inner rings in Figure 12 represents a fraction greater than a single particle inventory (1.32E-4). The inner rings from Capsules 3 and 7 had the highest Eu-154 inventories at approximately 33 particle equivalents and 229 particle equivalents, 
respectively. Given that 80 DTF particles are in each capsule, the value for Capsule 7 in particular indicates that the Eu-154 released from intact driver particles exceeded the contribution from the DTF particles. In all capsules, it is not clear how much of the Eu-154 detected in the inner ring is due to the DTF particles and how much is due to the driver fuel particles. High-temperature testing of AGR-3/4 Compact 3-2 at temperatures of 1600 and $1700^{\circ} \mathrm{C}$ suggests that the DTF particles do indeed contribute to additional releases beyond what is observed from AGR-1 and AGR-2 compacts with only intact TRISO particles, but radial deconsolidation-leach-burn-leach (R-DLBL) analysis is required to determine how much Eu-154 was retained in DTF particles and in the compact outside of the SiC layer (see future work in Section 5).

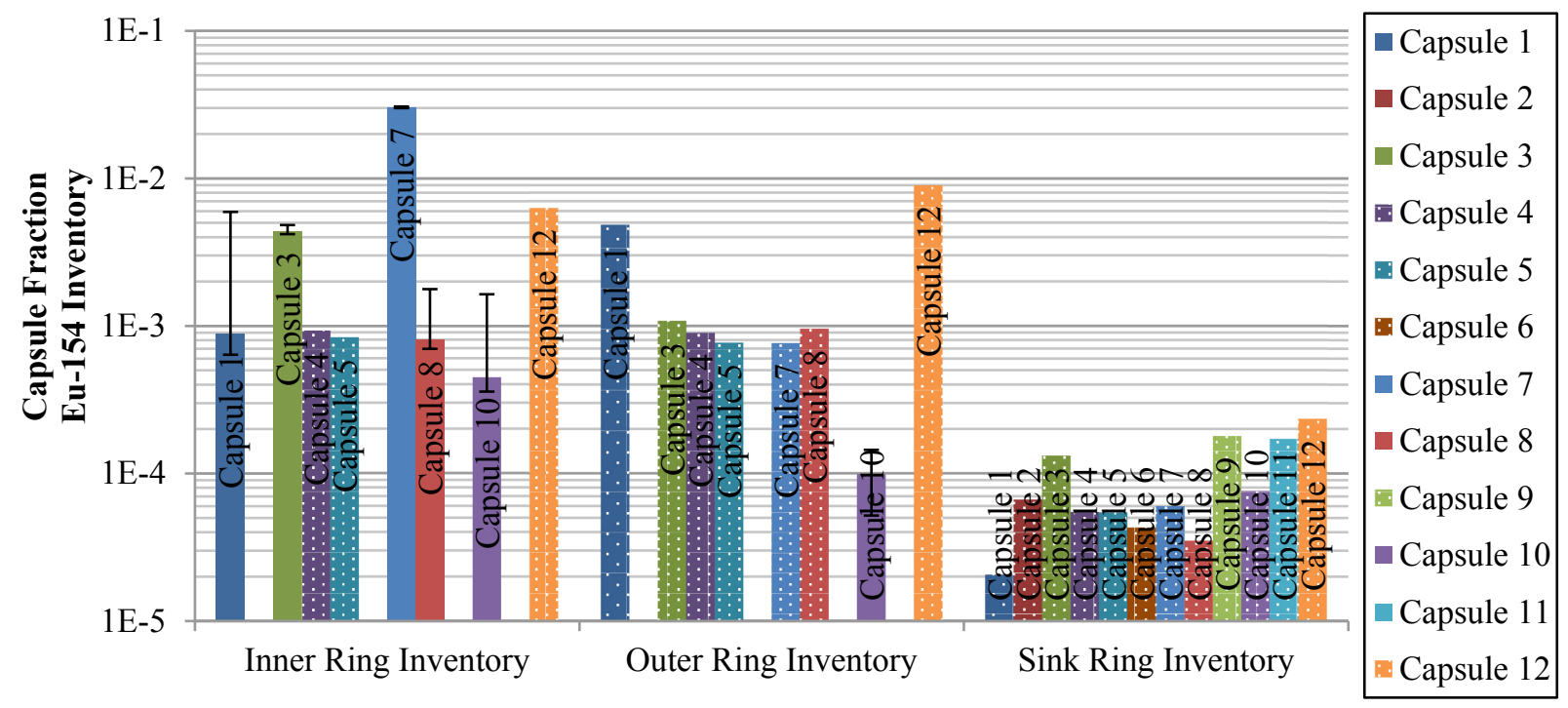

Figure 12. Inner, outer, and sink ring Eu-154 capsule fractions. Bars with patterned fill are based on MDAs.

\subsection{Ring Inventories Related to Irradiation Temperature}

No strong temperature dependence of the inner or outer ring cesium, europium, or silver inventories based on the irradiation temperature of those rings was apparent. This could be due to the fact that the inner and outer rings have complicated influxes and outfluxes of fission products related to temperature, the ring material, and adsorption/desorption processes. Complicating the matter further is the apparent axial transport of fission products evidenced by substantial fission product inventories on capsule spacers, foils, and felts (located at the top and bottom of the compact stack in each capsule), and in the axially asymmetrical inventories measured in the inner and outer rings by PGS (Harp et al. 2016a).

A temperature dependence was found, however, when the sink ring inventory was plotted as a function of the outer ring irradiation temperature (see Figure 13 and Figure 14). The sink ring was intended to act as a relatively cold medium (most sink rings had irradiation temperatures near $600^{\circ} \mathrm{C}$ ) to collect all fission products that migrated beyond the outer ring. In Figure 13, an exponential dependence between the sink ring Ag-110m inventory and the outer ring irradiation temperature was observed. The Cs-134 inventory in the sink ring was plotted as a function of the outer ring temperature, and a linear dependence was observed in Figure 14. 


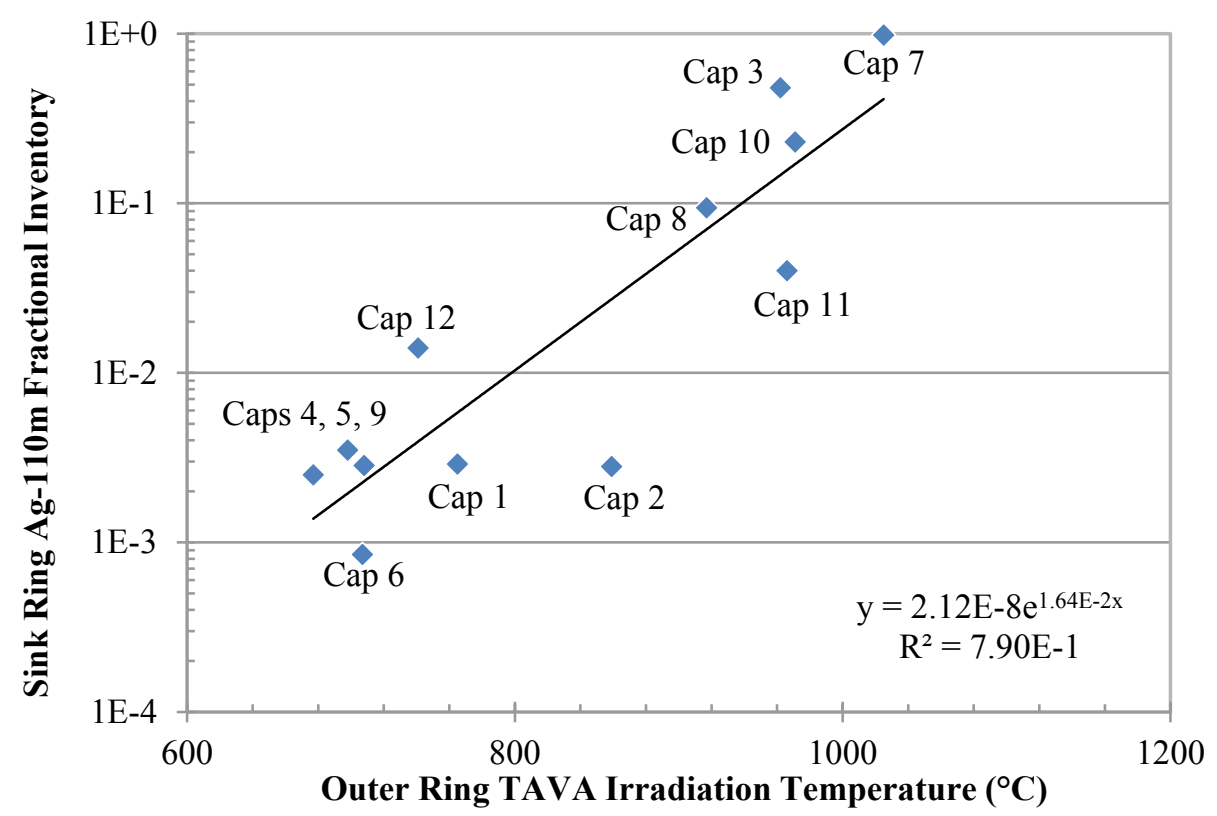

Figure 13. Sink ring Ag-110m inventories versus outer ring TAVA temperatures.

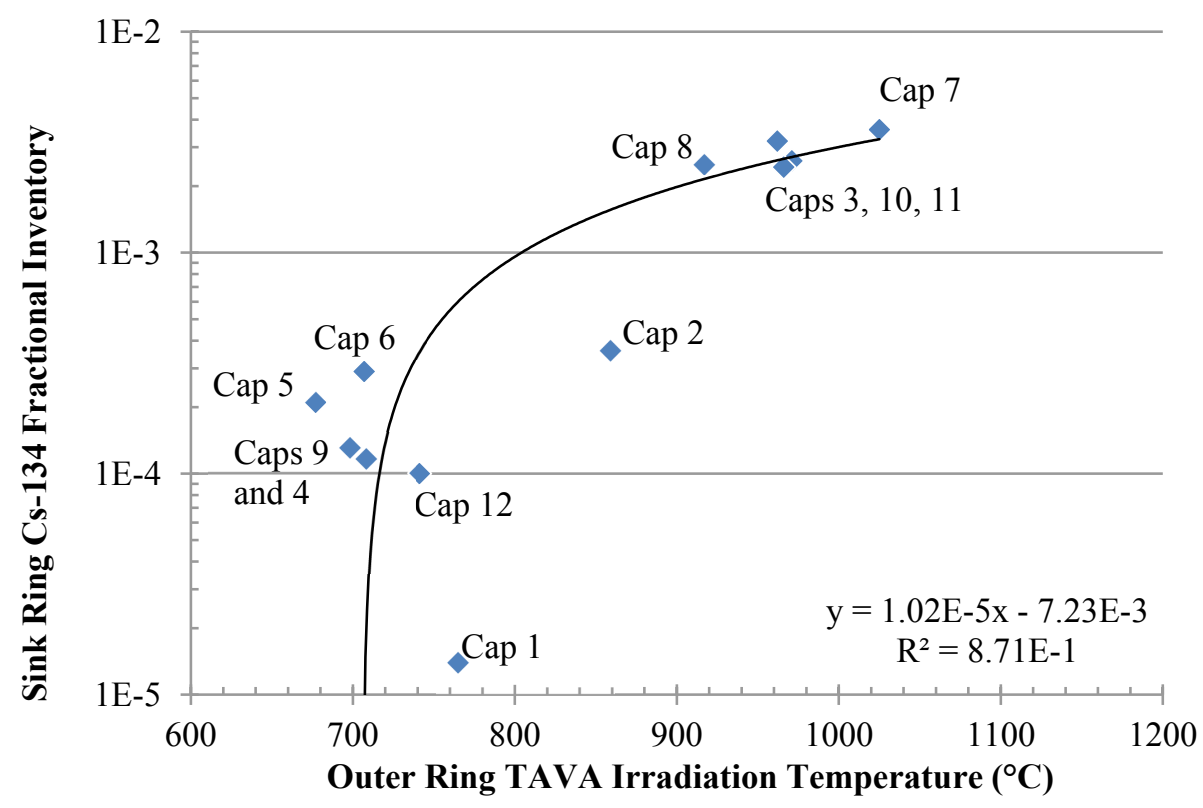

Figure 14. Sink ring Cs-134 inventories versus outer ring TAVA temperatures.

\subsection{Capsule-wide Mass Balance}

\subsubsection{Mass Balance of All Non-Silver Isotopes}

4.3.1.1 Antimony. Sb-125 was frequently detected on capsule components except for the inner and outer rings. Sb-125 was not reported in the PGS results of inner and outer ring scans. However, the zircaloy-4 spacers used in Capsules 1 through 6 contained tin as an alloying agent, and some natural isotopes of tin transmuted to Sb-125. This resulted in spuriously high fractions ( $>50 \%$ of the entire capsule inventory produced in the fuel) of Sb-125 being measured on the spacers and occasionally in the sink rings of these capsules. In Capsules 7 through 12, where zirconia spacers were used, Sb-125 fractions 
measured outside of the fuel typically ranged from 6E-4 to 3E-3. Given the incomplete balance of Sb-125 (because it was not measured on PGS), and the interference caused by transmutation in zircaloy-4 spacers, Sb-125 results were not presented in the tables or plots in this report.

4.3.1.2 Cerium and Ruthenium. No cerium or ruthenium results were reported from PGS of the inner and outer rings. Based on the other capsule components, cerium generally appears to be wellretained, even in the DTF kernels. In Table 29, 0.1 particle equivalents is the highest of the sums of measured values ("low" estimate), and less than 0.3 particle equivalents is the highest of the "high" estimates of Ce-144 activity outside of the fuel. Similarly, very little Ru-106 was measured outside of the fuel only in Capsules 8-10 and 12. The highest measured Ru-106 level was a fraction of 3E-6 Ru-106 in Capsule 10 (see Table 28).

4.3.1.3 Cesium. Table 29 presents fission product releases as the number of equivalent particle inventories. Cesium is well-retained in intact TRISO coatings but not well-retained by intact pyrocarbon, so significant release was expected from the DTF particles. Greater than 30 particles worth of Cs-134 was measured outside of the fuel compacts in Capsules 3-5, 7, 8, and 10. In Capsule 11 (an intact fuel body), 26 particle equivalents of Cs-134 was measured outside of the outer ring. Based on experience from AGR-1, it is very unlikely that any driver particles failed during the irradiation; therefore, this cesium is assumed to be overwhelmingly dominated by release from DTF particles.

There are several possible factors or combinations of factors that may explain why $<80$ particle equivalents of cesium have been measured outside of the fuel. First, appreciable cesium inventory could be retained in DTF particles, including within the DTF kernels. AGR-1 PIE and PIE safety test data indicate that the level of cesium released from particles that experienced $\mathrm{SiC}$ failure (whether failure occurs in-pile or during post-irradiation heating at elevated temperatures) can vary significantly. In AGR-1, in-pile cesium releases from particles with failed SiC layers ranged from about $27 \%$ to $96 \%$ (Hunn et al. 2016). Second, it is possible that some cesium produced in the DTF particles remains in the compact graphitic matrix. Third, some cesium could have transported beyond the sink ring to the capsule shell, which was not analyzed. This seems possible for the hottest capsules in the experiment (Capsules 3, $7,8,10$, and 11) which had greater than a fraction of $2.4 \mathrm{E}-3$ ( $>18$ particle equivalents) measured on the sink rings. It is less likely for the other capsules which had $<3$ particle equivalents measured in sink rings. Radial deconsolidation-leach-burn-leach (R-DLBL) of selected fuel compacts is expected to help elucidate the inventory remaining in DTF particles and the compact matrix. (See Section 5 for description of the R-DLBL process.)

4.3.1.4 Europium. Significant europium was detected outside of the fuel compacts. Excluding fuel bodies that were retained intact so that their inner and outer rings could not be measured (Capsules 2, 6, 9, and 11), the "low" estimate of Eu-154 releases ranged from a fraction of about 1E-3 in Capsule 1 up to 3.1E-2 for Capsule 7. ${ }^{\mathrm{d}}$ Again, excluding the intact fuel bodies, the "high" estimates of fractional release ranged from 1.3E-3 for Capsule 10 to 3.2E-2 for Capsule 7. For comparison, the highest in-pile fractional Eu-154 release from AGR-1 fuel compacts was lower at 4.6E-4 (Demkowicz et al. 2016). The highest in-pile Eu-154 fractional inventory in an AGR-2 graphite holder was 3.7E-2 from AGR-2 Capsule 2 (Harp et al. 2016c), slightly higher than in AGR-3/4 Capsule 7.

The differences between AGR-3/4 Capsule 7 and AGR-1 Capsule 6 europium releases, and the similarities between AGR-3/4 Capsule 7 and AGR-2 Capsule 2 europium release may be related to the time and temperature of the irradiations. AGR-3/4 Capsule 7 had the highest fuel compact TAVA irradiation temperature of any AGR irradiation capsule to date at $1345^{\circ} \mathrm{C}$. AGR-1 Capsule 6 (the hottest AGR-1 capsule) had a TAVA temperature of $1087^{\circ} \mathrm{C}$, and the hottest AGR-2 Capsule (Capsule 2) had a TAVA temperature of $1252^{\circ} \mathrm{C}$. The AGR-3/4 irradiation ran for 369 effective full power days (EFPD) in

d Capsules 4 and 5 had "low" estimates of fractional Eu-154 releases of 0.0; however, the spacers were not recovered from Capsule 5, and the foils and felts were not recovered from Capsule 4. It is possible that europium could have been retained on those missing components. 
ATR, AGR-2 ran for 559 EFPD, and AGR-1 ran for 620 EFPD. So while AGR-3/4 was a shorter irradiation, Capsule 7 had much higher temperatures than AGR-1 Capsule 6 and significantly higher temperatures than the longer AGR-2 Capsule 2 irradiation. This suggests a possible acceleration in the europium release rate from compacts for irradiation temperatures greater than roughly $1200^{\circ} \mathrm{C}$.

While the 80 DTF particles in AGR-3/4 Capsule 7 likely contributed to the measured Eu-154 releases, Table 29 shows that the Capsule $7 \mathrm{Eu}-154$ release is about 230 particle equivalents, considerably more than would have come from 80 DTF particles. Thus in Capsule 7, it is concluded that the high irradiation temperature resulted in diffusive release of Eu-154 through intact driver particle TRISO coatings such that total releases from the approximately 7488 driver particles exceeded that from the 80 DTF particles. Past AGR PIE efforts have demonstrated that europium is significantly retained in the compact matrix during irradiation (Demkowicz et al. 2016). It is therefore expected that release from the driver particles is appreciably higher than the levels suggested from the inventory quantified outside of the compacts, with much of the inventory released from particles still remaining within the compacts. RDLBL analysis of selected fuel compacts will aid in determining the effective release from fuel particles. In addition, in cases where release from the driver particles is particularly high (e.g., higher than approximately 5-10\%), gamma counting of individual particles and comparing the remaining inventory to the predicted inventory may also help to quantify total particle release.

4.3.1.5 Strontium. Based on past observations of fission product transport in coated particle fuel systems, it is generally assumed that Sr-90 behavior/transport will be similar to that of Eu-154/155, and in a number of cases, looking at the hardware inventory tables for each capsule, the Sr-90 and Eu-154 release fractions are similar. Since Sr-90 is a beta-emitter, its inventory on inner and outer rings can only be determined via destructive methods. Therefore, the capsule-wide Sr-90 mass balances are incomplete. Only inner and outer rings from Capsules 3, 5, 7, and 8 have been partially sampled via milling/machining (see Section 2.2.2). Additional analysis is required before the Sr-90 balance for these capsules can be completed. The highest measured Sr-90 values summed across all available capsule components (excluding the inner and outer rings) came from Capsules 3, 7, and 10, and are equivalent to about 2 to 3 particle equivalents. This means that little Sr-90 transported beyond the outer rings. These incomplete mass balances are about an order of magnitude higher than the entire in-pile Sr-90 releases from AGR-1 Capsule 1 and two orders of magnitude higher than the other AGR-1 capsules. ${ }^{\mathrm{e}}$ As in the case of europium, this could be due substantially to the DTF particles and higher irradiation temperatures in several of the AGR-3/4 capsules causing diffusive release from driver particles.

4.3.1.6 Releases as a Function of Temperature. Figure 15 shows the fraction of Cs- 134 and Eu-154 measured outside of the fuel for all standard (non-fuel body) capsules as a function of the TAVA irradiation temperature among the compacts within each capsule. It also includes the Sr-90 inventory in the capsule components (i.e., outside of the compacts, inner ring, and outer ring). This is effectively the release of these fission products from the fuel compacts as a function of the compacts irradiation temperature. The dashed line represents the capsule fraction equivalent to 80 DTF particles. The "low" (sum of measured values only, no MDAs) and "high" (measured values plus MDAs) are plotted for Eu154 and Cs-134. The true value of the Eu-154 and Cs-134 releases lies somewhere between the low and high values. The error bars are placed on the "low" data points, and in most cases, the bars are smaller than the size of the chart symbols. Sr-90 was counted via a completely different method (burn-leach, separation on an ion exchange column, and gas proportional counting), and as a result, all sample analyses resulted in measured values.

Below $1000^{\circ} \mathrm{C}$, the Cs- 134 releases are less than a fraction of $1 \mathrm{E}-3$. Above $1000^{\circ} \mathrm{C}$, the Cs- 134 releases range from about $5 \mathrm{E}-3$ to $1 \mathrm{E}-2$. This equates to 50 to $100 \%$ of the entire DTF inventory in a capsule. Capsules 4 and 5 had the highest measured quantities of Cs-134. It is not clear why these rings

\footnotetext{
${ }^{\text {e }}$ Burn-leach of the AGR-2 compact holders has been recently completed, and analysis of the Sr-90 balance in the AGR-2 experiment is in progress.
} 
would have high levels of Cs-134. During Capsule 4 and 5 disassembly (but not necessarily during irradiation) there was some contact between the compacts and the inner rings. The compacts could have become skewed in the inner rings during disassembly. Ultimately, an arbor press was used to force the compacts out (Stempien et al. 2016). The apparent upper limit on cesium release equivalent to approximately the inventory of the DTF particles is consistent with observations to date from PIE of the other AGR experiments. In particular, it indicates that release of cesium from intact TRISO particles is negligible, and therefore the only appreciable source of cesium released from the compacts is the DTF particles.

The "low" values for Eu-154 release decrease slightly from Capsule 12 to Capsule 1; increase a little from Capsule 1 to Capsules 3, 8, and 10; and increase significantly between Capsules 3, 8, and 10 and Capsule 7. Eu-154 was not detected outside of the fuel in Capsules 4 and 5; therefore, the "low" value is of 0 is not shown in the plot. The Capsule 4 foils and felts were not recovered, the Capsule 5 spacers were not recovered, and only one Capsule 7 spacer was recovered. Based on the results from other capsules, these components could potentially contain a significant activity of Eu-154, so it is possible that the Eu154 inventory outside of the fuel compacts in Capsules 4, 5, and 7 is biased low. Since the true value of Eu-154 releases is somewhere between the "low" and "high" values, if the true Capsule 1 and 12 values lie closer to the "low" value, and the Capsule 4 and 5 values lie closer to the "high" values, then the Eu- 154 releases may be relatively flat from $800^{\circ} \mathrm{C}$ to $1200^{\circ} \mathrm{C}$, beginning to increase around $1200^{\circ} \mathrm{C}$, and increasing substantially above $1200^{\circ} \mathrm{C}$.

The Sr-90 mass balance outside of the fuel is not complete, as values are not available for the inner and outer rings. Some inner and outer rings have been partially sampled (roughly $40 \%$ of the volume was sampled from the 8 rings selected for sampling), and the samples have undergone partial burn-leach analysis. However, additional analysis is required before the Sr-90 mass balance for any capsule is complete. The Sr-90 values in Figure 15 represent the Sr-90 inventory in the sink rings, foils, spacers, and through tubes. Similar to Eu-154, the Sr-90 fraction on the aforementioned hardware decreases slightly from Capsule 12 to Capsule 1. Then the fraction on the Capsule 4 and 5 hardware (at roughly $1000^{\circ} \mathrm{C}$ ) is similar to that in Capsule 1 (at roughly $930^{\circ} \mathrm{C}$ ). The Sr-90 fraction on the Capsules 3, 8, and 10 hardware (at nearly $1200^{\circ} \mathrm{C}$ ) is about at least 10 times greater than on Capsules 1, 4, and 5. The Sr-90 on the Capsule 7 hardware is higher still. This may suggest an increase in the $\mathrm{Sr}-90$ release beginning somewhere between about $1000^{\circ} \mathrm{C}$ and $1200^{\circ} \mathrm{C}$. 


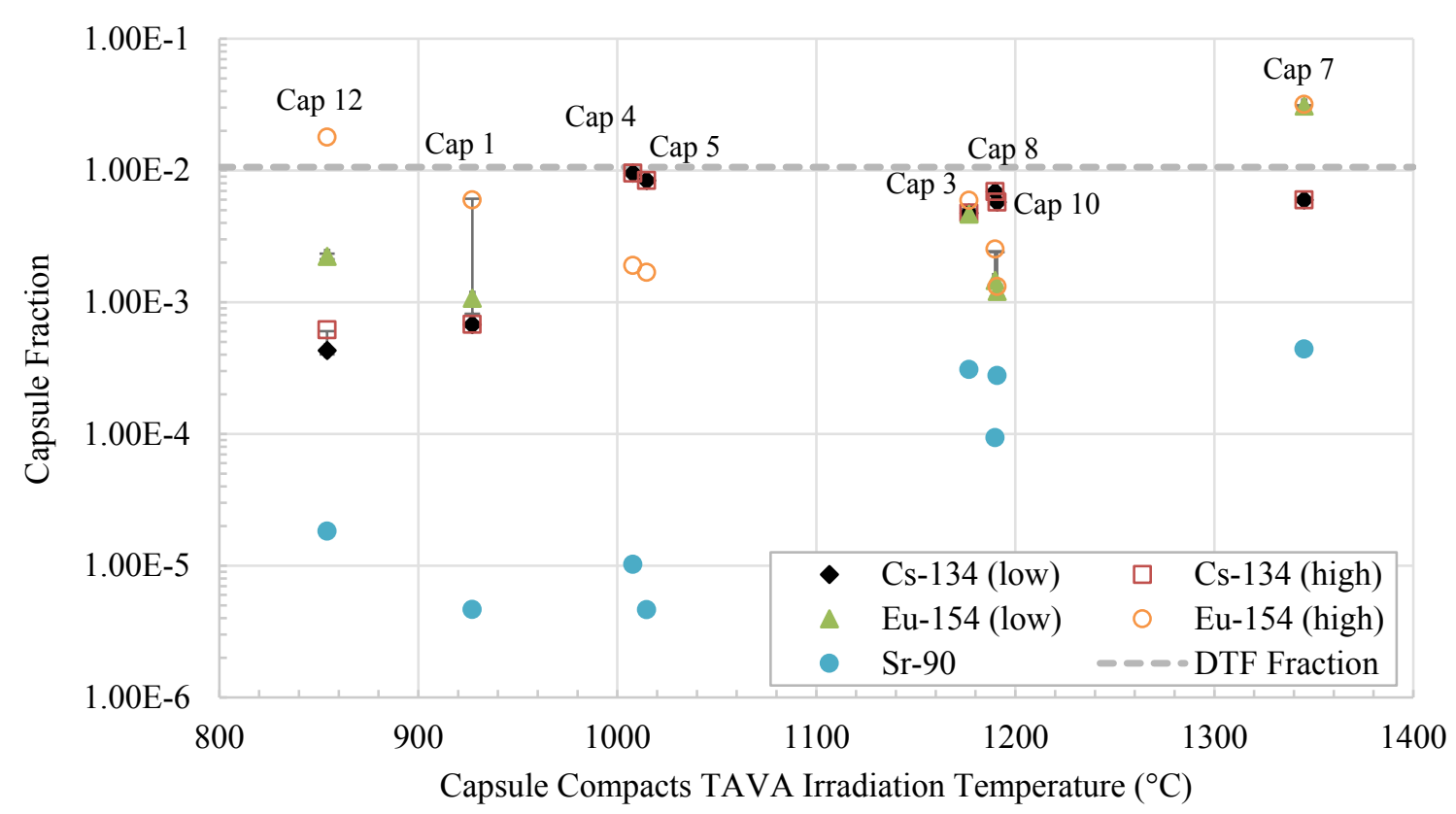

Figure 15. Total fraction of Cs-134 and Eu-154 measured outside of the fuel in all standard-type capsules. "Low" values are measured values only (no values derived from MDAs). "High" values are the low values plus MDAs from instances where a given isotope was not detected. NOTE: $\mathrm{Sr}$ 90 is not a complete balance because inner and outer rings require destructive analysis for measurement.

\subsubsection{Silver Mass Balance}

In addition to analyzing the fission product inventory on all available capsule components (inner/outer/sink rings, foils, spacers, felts, through tubes, etc.), all compacts from capsules 1, 3, 4, 5, 7, 8, 10, and 12 were gamma counted (Harp et al. 2016a). The measured activities (M) were compared to the calculated inventories $(\mathrm{C})$ to give a measured-to-calculated ratio $(\mathrm{M} / \mathrm{C})$. For most fission products, the level of release from the compacts is low enough (less than a few percent) that no meaningful conclusion about release can be drawn by examining the remaining inventory, especially in light of the measurement uncertainty from gamma spectrometry and the potential calculational bias in the predicted fission product inventories. However, silver release is often sufficiently high (tens of percent) that the $\mathrm{M} / \mathrm{C}$ ratio can provide information on the extent of fission product silver release from the compact.

Figure 16 shows the Ag-110m M/C values for each compact as a function of the compact TAVA irradiation temperatures. Compacts at the low TAVA temperatures were low burnup compacts (burnup $<7.0 \%$ FIMA) from Capsules 1 and 12 . These compacts also exhibit the largest uncertainty in $\mathrm{M} / \mathrm{C}$ values. Note that the error bars are asymmetrical based on the method employed to determine the uncertainty of measurements made with the PGS (Harp et al. 2016b). The relatively large magnitude of these uncertainties is due to the fact that these compacts had much smaller absolute quantities of Ag$110 \mathrm{~m}$ produced during irradiation. It is notable that the $\mathrm{M} / \mathrm{C}$ values drop sharply above $1100^{\circ} \mathrm{C}$. This could be related to a rapid increase in the silver diffusion rate through intact $\mathrm{SiC}$ layers at intermediate temperatures ranging from approximately $1100^{\circ} \mathrm{C}$ to $1300^{\circ} \mathrm{C}$ observed during post-irradiation heating testing (Hunn et al. 2015). 


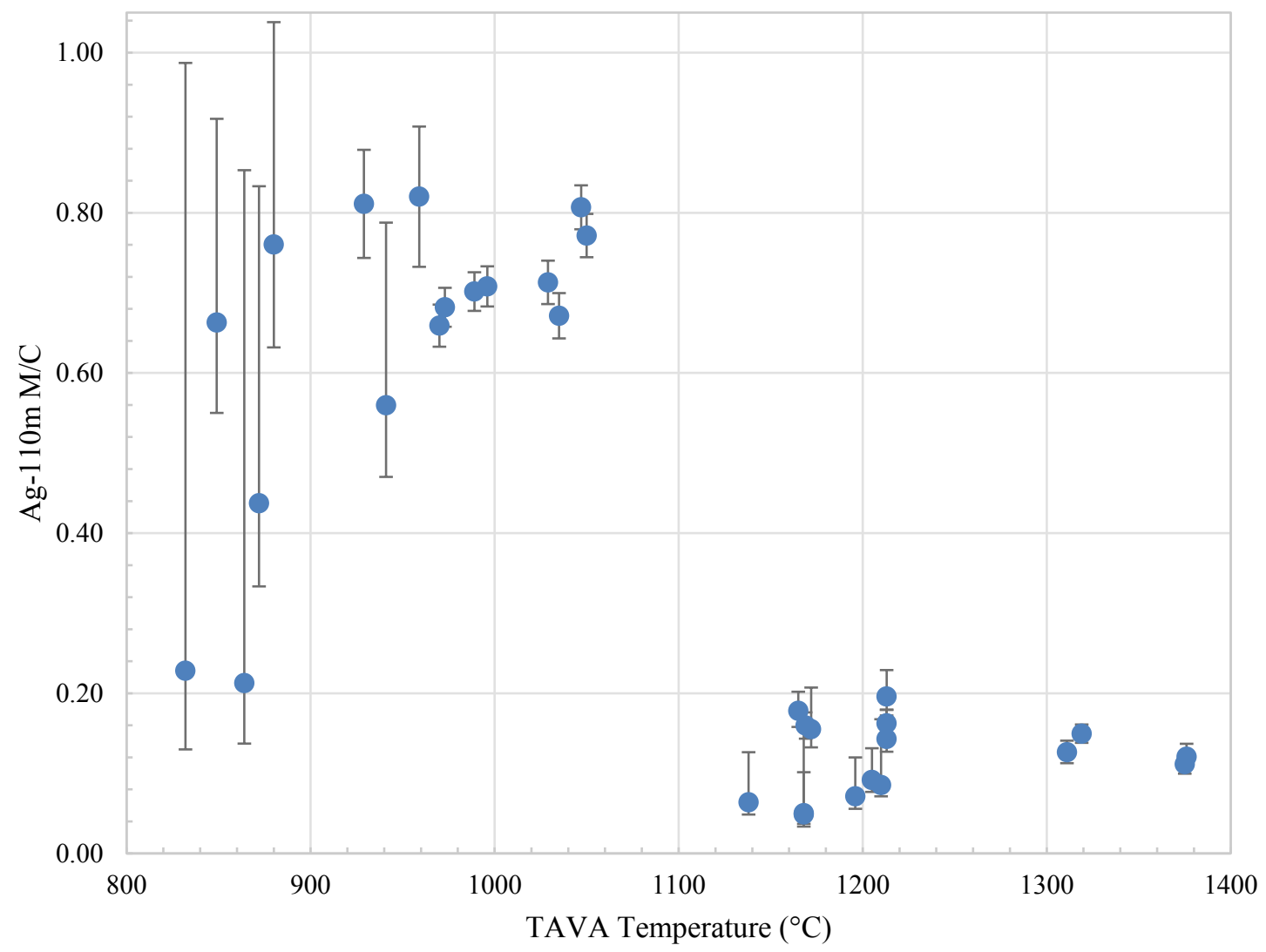

Figure 16. Ag-110m measured-to-calculated ratios versus compact TAVA irradiation temperature.

Figure 17 shows the Ag-110m mass balance for each capsule and each component within each capsule expressed as a fraction of the predicted capsule inventory. The sum of the fractional inventory from each component within each capsule is listed across the top of each column. In this plot, if Ag- $110 \mathrm{~m}$ was not measured on a given component, an MDA was determined, converted into an M/C value, and this value was included as if it were a true measurement. Capsules 2, 6, 9, and 11 are not included because they are intact fuel bodies for which the Ag-110m balance is incomplete because the inner and outer rings and compacts were not measured. Values slightly greater than 1.0 indicate that the predicted Ag- $110 \mathrm{~m}$ inventory in the capsule is slightly low or that the measured values are biased high.

Figure 18 shows the Ag-110m mass balance for each capsule and each component within each capsule expressed as a fraction of the predicted capsule inventory. The sum of the fractional inventory from each component within each capsule is listed across the top of each column. In this plot, if Ag-110m was not measured on a given component, that was taken as a value of zero. Ag-110m was detected in all compacts that were scanned on the PGS; however, the total Ag-110m inventory of a compact is the sum of multiple individual scans, and occasionally some individual scans in a compact did not have measureable Ag-110m. In that case, an MDA was determined for that scan and incorporated into the uncertainty in the final reported value. As Figure 16 shows, the compact PGS Ag-110m uncertainty was largest for Capsules 1 and 12, but these uncertainties were not incorporated into Figure 17 or Figure 18. Only a single value was used for each compact. Capsules 2, 6, 9, and 11 are not included because they are intact fuel bodies for which the Ag-110m balance is incomplete because the inner and outer rings and compacts were not measured. Values slightly greater than 1.0 indicate that the predicted Ag- $110 \mathrm{~m}$ inventory in the capsule is slightly low or that the measured values are biased high. The capsule 
inventories most affected by taking the MDAs to be zeros are those for Capsules 1 and 12 at the top and bottom of the AGR-3/4 irradiation test train. In Figure 18 the total Ag- $110 \mathrm{~m} \mathrm{M} / \mathrm{C}$ for Capsule 1 is 0.12 lower and for Capsule 12 it is 0.41 lower when compared to Figure 17. This highlights the additional uncertainty in measuring Ag-110m in those capsules where less Ag-110m was released and less Ag-110m was produced (due to lower burnup in those capsules). Aside from Eu-154 releases in Capsule 7, Ag$110 \mathrm{~m}$ was the only radionuclide released from the compacts in quantities that greatly exceeded the inventory in the DTF particles.

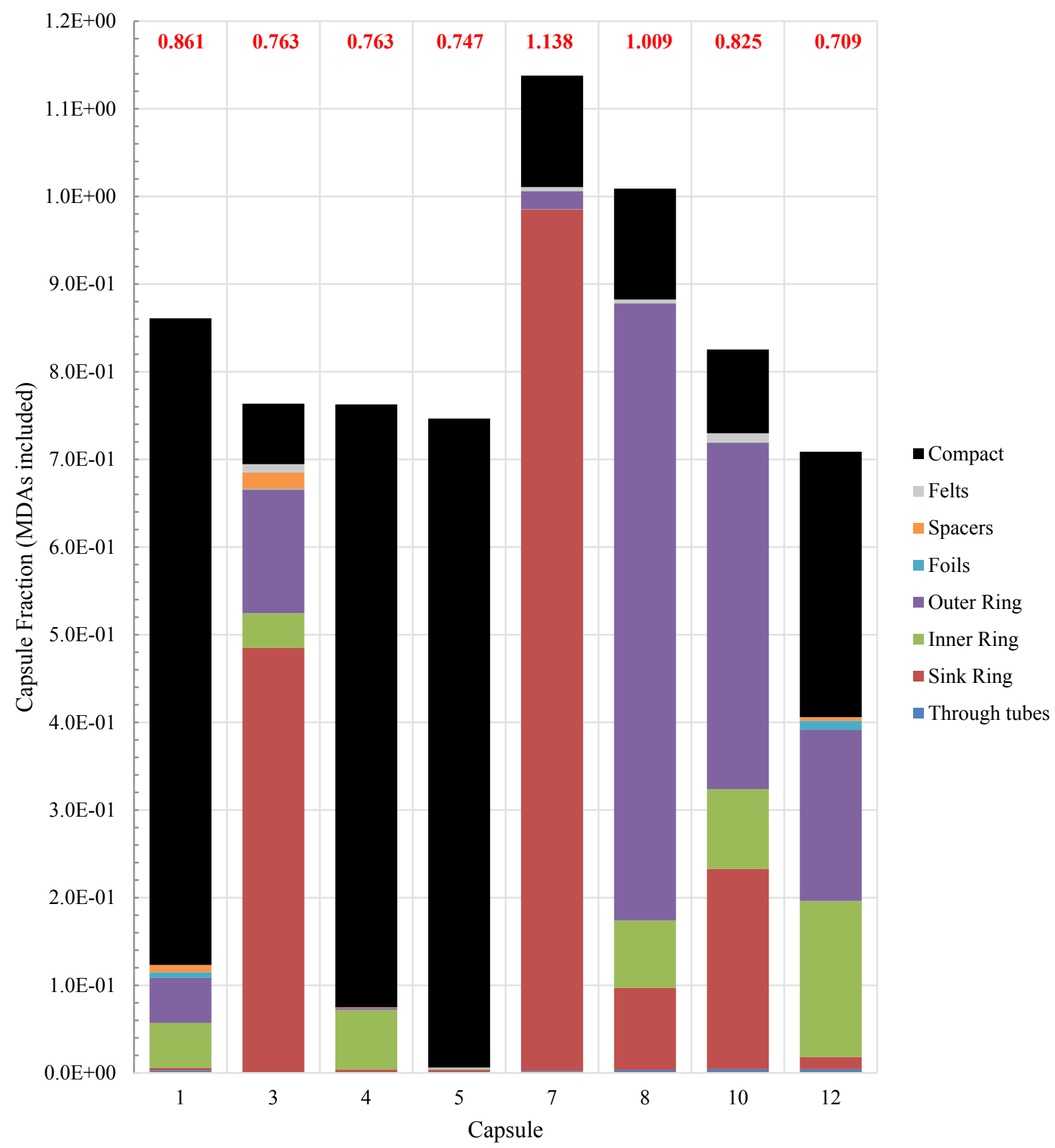

Figure 17. Fraction of predicted Ag-110m on all capsule components including compacts. Here, if no Ag-110m was detect, a value was determined based on MDAs and included in the plot. Across the top of each column is the total fraction from the sum of all components in each capsule. 


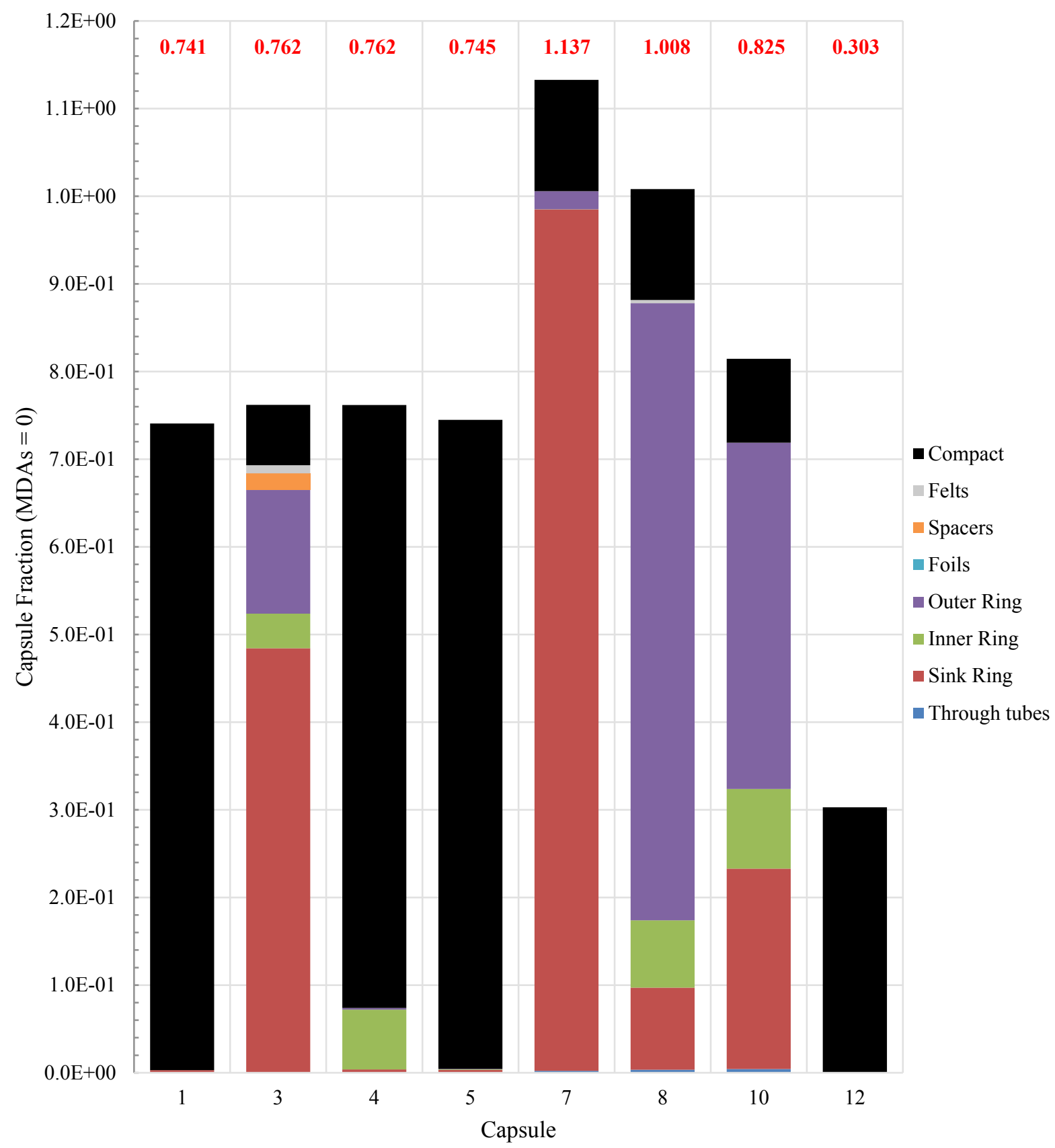

Figure 18. Fraction of predicted Ag-110m measured on all capsule components including compacts. Here, if no Ag-110m was detect, the Ag-110m value for that component was zero. Across the top of each column is the total fraction from the sum of all components in each capsule.

\section{CONCLUSIONS AND FUTURE WORK}

Major conclusions from the fission product mass balance are summarized as follows:

- The most commonly detected radionuclide fission products were Ag-110m, Cs-134, Cs-137, Eu-154, Eu-155, and Sr-90. 
- $\quad$ Sb-125 was also frequently detected; however, the zircaloy-4 spacers used in Capsules 1 through 6 contained natural tin that transmuted to Sb-125. Sb-125 was not detected on PGS, thus its balance is incomplete. In Capsules 7 through 12, where zirconia spacers were used, Sb-125 fractions measured on capsule components typically ranged from $6 \mathrm{E}-4$ to $3 \mathrm{E}-3$.

- Ag-110m was substantially released. Except for the coldest capsule in the irradiation (Capsule 12) and the un-opened fuel body (Capsule 2), Ag-110m was measured outside of the fuel in all other capsules. When detected, total Ag-110m release fractions ranged from about 3E-3 (roughly 22 particle equivalents in Capsule 1) to 1.01 (> 7600 particle equivalents in Capsule 7). Aside from Eu-154 releases in Capsule 7, Ag-110m was the only radionuclide released in quantities that greatly exceeded the inventory in the DTF particles.

- Greater than 30 particles worth of Cs-134 was measured outside of the fuel compacts in Capsules 3-5, 7, 8, and 10. In Capsule 11 (an intact fuel body), 26 particle equivalents of Cs-134 was measured outside of the outer ring. Based on experience from AGR-1, it is very unlikely that any driver particles failed during the irradiation and release from intact TRISO particles is expected to be extremely low; therefore, this cesium is assumed to be overwhelmingly dominated by release from DTF particles.

- Tens of particles worth of Eu-154 or Eu-155 were typically measured outside of the fuel (even in fuel body capsules for which the mass balance is incomplete). Compared to AGR-1 europium releases, the AGR-3/4 releases are significantly higher and can be at least partially attributed to the DTF particles. Irradiation temperature is also an important factor. The high irradiation temperature in Capsule 7 (highest in the AGR program to date) caused diffusive release of europium from intact driver particles such that the total europium release in Capsule 7 exceeded the inventory in the DTF particles by about a factor of three.

- The Sr-90 mass balance is incomplete due to the destructive analyses required on the inner and outer rings. Capsule 3, 7, 8, and 10 inner and outer rings have been partially, destructively sampled. After additional analysis, the Sr-90 results from these rings will be included along with the gamma-emitting fission products in the mass balance. The incomplete AGR-3/4 mass balances give about an order of magnitude higher release than the entire in-pile Sr-90 releases from AGR-1 Capsule 1 and two orders of magnitude higher than the other AGR-1 capsules. As in the case of europium, this is due substantially to the DTF particles. The high irradiation temperature in AGR-3/4 Capsule 7 is likely another contributor to $\mathrm{Sr}-90$ releases in that capsule.

- There may be some discernable temperature dependence on the measured fission product releases.

- Ag- $110 \mathrm{~m}$ release from the compacts appears to increase sharply at $1100^{\circ} \mathrm{C}$.

- Cs-134 releases from DTF kernels appear to increase between 900 and $1000^{\circ} \mathrm{C}$. Above $1000^{\circ} \mathrm{C}$ the total Cs-134 release from the fuel compacts ranges from about $50 \%$ to near $100 \%$ of the DTF inventory.

- Eu-154 releases from the compacts appear to increase at irradiation temperatures above $1200^{\circ} \mathrm{C}$

- For Sr-90, there may be an increase in the release rate beginning somewhere between irradiation temperatures of about $1000^{\circ} \mathrm{C}$ and $1200^{\circ} \mathrm{C}$.

- The measured sink ring inventories of Ag-110m are exponentially related to the irradiation temperature of the outer ring.

- The measured sink ring inventories of Cs-134 are linearly related to the irradiation temperature of the outer ring. 
- Substantial radial transport of fission products did occur through the inner, outer, and sink rings. In some cases (particularly in the hottest 4 capsules), the outer and sink rings may have higher inventories of Ag-110m and Cs-134 than the inner rings.

This report has focused on the fission product inventory outside of the fuel compacts. A key data need in the AGR-3/4 fission product transport analysis is the inventory of fission products residing in the compact matrix outside of the fuel particles. Standard deconsolidation-leach-burn-leach (DLBL) analysis would be ineffective for determining this, since it would result in dissolution of the exposed DTF kernels during the process. Certain compacts were selected for the first round of the new R-DLBL analysis process developed to address this data need (Stempien 2017). In this method, material (matrix debris and particles) is removed around the circumference of the compact in several steps of known thickness. The deconsolidation solution and particles from each step are analyzed to determine a radial profile of fission product concentrations in the compact outside of the particle SiC layer. The final step of the R-DLBL is the axial deconsolidation of the core of the compact that contains the DTF particles. Several compacts have undergone R-DLBL analysis (Stempien 2017), and additional compacts in the as-irradiated condition and after high-temperature post-irradiation compact heating tests in the Fuel Accident Condition Simulator furnace will undergo R-DLBL as described in the AGR-3/4 Phase 2 PIE Plan (Demkowicz 2017). Preliminary data from these initial analyses are not yet available, but will be presented in subsequent reports and publications.

\section{REFERENCES}

Chadwick, M. B., et al., 2011, "ENDF/B-VII.1 Nuclear Data for Science and Technology: Cross-Sections, Covariances, Fission Product Yields and Decay Data," Nuclear Data Sheets, Vol. 112, pp. 2887-2996 specific decay data accessed 2013-07-09 at http://www.nndc.bnl.gov/endf/b7.1/.

Collin, B.P., 2011, “AGR-2 Irradiation Experiment Test Plan,” PLN-3798, Rev. 1, October 2011, Idaho National Laboratory.

Collin, B.P., 2014, “AGR-2 Irradiation Test Final As-Run Report,” INL/EXT-14-32277, Rev. 2, August 2014, Idaho National Laboratory.

Collin, B.P., 2015a, “AGR-1 Irradiation Test Final As-Run Report,” INL/EXT-10-18097, Rev. 3, January 2015, Idaho National Laboratory.

Collin, B.P., 2015b, “AGR-3/4 Irradiation Test Final As-Run Report”, INL/EXT-15-35550, Rev. 0, Idaho National Laboratory, June 2015.

Collin, B.P., 2015c, “AGR-3/4 Irradiation Experiment Test Plan,” PLN-3867, Rev. 1, Idaho National Laboratory.

Collin, B.P., 2018, “AGR-5/6/7 Irradiation Experiment Test Plan,” PLN-5245, Rev. 1, January 2018, Idaho National Laboratory.

Collin, B.P., Demkowicz, P.A., Petti, D.A., Hawkes, G.L., Palmer, J., Pham, B.T., Scates, D.M., Sterbentz, J.W., 2018, "The AGR-3/4 fission product transport irradiation experiment," Nuclear Engineering and Design, 327 (2018) 212-227.

Demkowicz, P. A., “AGR-2 Post-Irradiation Examination Plan”, PLN-4616, Rev. 0, December 2013, Idaho National Laboratory.

Demkowicz, P. A., Hunn, J. D., Morris, R. N., van Rooyen, I., Gerczak, T., Harp, J. M. and Ploger, S. A., 2015a, "AGR-1 Post-Irradiation Examination Final Report," INL/EXT-15-36407, Idaho National Laboratory. 
Demkowicz, P.A., Hunn, J.D., Ploger, S.A., Morris, R.N., Baldwin, C.A., Harp, J.M., Winston, P.L., Gerczak, T.J., van Rooyen, I.J., Montgomery, F.C., and Silva, C.M., (2016), "Irradiation Performance of AGR-1 high temperature reactor fuel," Nuclear Engineering and Design, 306 (2016), 2-13.

Demkowicz, P. A., “AGR-3/4 Phase 2 Post-Irradiation Examination Plan,” PLN-5382, May 2017, Idaho National Laboratory.

Harp, J.M., Demkowicz, P.A., Stempien, J.D., 2016a, "Initial Gamma Spectrometry Examination of the AGR-3/4 Irradiation”, Paper 18594, HTR 2016 Las Vegas, NV USA, Nov 6-10, 2016.

Harp, J.M., Demkowicz, P.A., Stempien, J.D., 2016b, "Fission Product Inventory and Burnup Evaluation of the AGR-2 Irradiation by Gamma Spectrometry", Paper 18593, HTR 2016 Las Vegas, NV USA, Nov 6-10, 2016.

Harp, J.M., Demkowicz, P.A., Stempien, J.D., 2016c, "Fission Product Inventory and Burnup Evaluation by Gamma Spectrometry of the AGR-2 Irradiation," INL/EXT-16-3977, Idaho National Laboratory.

Hawkes, G., 2014a, “AGR-1 Daily As-Run Thermal Analyses,” ECAR-9638, Rev. 4, September 2014, Idaho National Laboratory.

Hawkes, G., 2014b, “AGR-2 Daily As-Run Thermal Analyses,” ECAR-2476, Rev. 1, August 2014, Idaho National Laboratory.

Hawkes, G., 2016, “AGR-3/4 Daily As-Run Thermal Analyses,” ECAR-2807, Rev. 1, April 2016, Idaho National Laboratory.

Humrickhouse, P.W., Collin, B.P., Hawkes, G.L., Harp, J.M., Demkowicz, P.A., and Petti, D.A., 2016, "Modeling and Analysis of Fission Product Transport in the AGR-3/4 Experiment", HTR 2016, Paper 18693, Las Vegas, NV USA, Nov 6-10, 2016.

Hunn, J.D., Lowden, R.A., 2007, "Data Compilation for AGR-3/4 Driver Fuel Coated Particle Composite LEU03-09T”, ORNL/TM-2007/019, Oak Ridge National Laboratory.

Hunn, J.D., Miller, J.H., 2009, "Data Compilation for AGR-3/4 Designed-to-Fail (DTF) Fuel Particle Batch LEU04-02DTF”, ORNL/TM-2008/193, October 2009, Oak Ridge National Laboratory.

Hunn, J., Trammell, M.P., Montgomery, F.C., 2011, "Data Compilation for AGR-3/4 Designed-to-Fail (DTF) Fuel Compact Lot (LEU03-10TOP2/LEU03-07DTF-OP1)-Z”, ORNL/TM-2011/124, Oak Ridge National Laboratory.

Hunn, J.D., Lowden, R.A., Miller, J.H., Jolly, B.C., Trammell, M.P., Kercher, A.K., Montgomery, F.C., and Silva, C.M., 2014, "Fabrication and Characterization of Driver Fuel Particles, Designed-to-Fail Fuel Particles, and Fuel Compacts for the US AGR-3/4 Irradiation Test, Nuclear Engineering and Design 271 (2014) 123-130.

Hunn, J.D., Morris, R.N., Baldwin, C.A., Montgomery, F.C., Gerczak, T.J., 2015, "PIE on Safety-Tested AGR-1 Compact 4-2-2,” ORNL/TM-2015/033, Oak Ridge National Laboratory.

Hunn, J.D., Baldwin, C.A., Gerczak, T.J., Montgomery, F.C., Morris, R.N., Chinthaka, M.S., Demkowicz, P.A., Harp, J.M., Ploger, S.A., van Rooyen, I., and Wright, K.E., (2016), "Detection and analysis of particles with failed SiC in AGR-1 fuel compacts," Nuclear Engineering and Design 306 (2016) 36-46.

INL, 2017, “Technical Program Plan for INL Advanced Reactor Technologies Technology Develop Office/Advanced Gas Reactor Fuel Development and Qualification Program," PLN-3636, Revision 6, June 2017, Idaho National Laboratory. 
Kercher, A.K. and Hunn, J.D., 2006, "Results from ORNL Characterization of Nominal $350 \mu \mathrm{m}$ LEUCO Kernels (LEU03) from the BWXT G73V-20-69303 Composite”, ORNL/TM-2006/552, October 2006, Oak Ridge National Laboratory.

Kercher, A.K., Jolly, B.C., Montgomery, F.C., Silva, G.W.C, and Hunn, J.D., 2011, "Data Compilation for AGR-3/4 Designed-to-Fail (DTF) Fuel Particle Batch LEU03-07DTF”, ORNL/TM-2011/109, Oak Ridge National Laboratory.

Ploger, S., Demkowicz, P. A., Harp, J. A., 2015, “AGR-2 Irradiated Test Train Preliminary Inspection and Disassembly First Look,” INL/EXT-15-34997, May 2015, Idaho National Laboratory.

Pool, K.N., 2018, “Sr-90 by Liquid Scintillation Spectrometry”, ASR 475.01, Batch 6, June 2018, Pacific Northwest National Laboratory.

Stempien, J.D., Rice, F.J., Winston, P.L., Harp, J.M., 2016, “AGR-3/4 Irradiation Test Train Disassembly and Component Metrology First Look Report”, INL/EXT-16-38005, September 2016, Idaho National Laboratory.

Stempien, J.D., Radial Deconsolidation and Leach-Burn-Leach of AGR-3/4 Compacts 3-3, 12-1, and 12-3, INL/EXT-17-43182, Idaho National Laboratory, 2017.

Sterbentz, J.W., 2013, "JMOCUP As-Run Daily Depletion Calculation for the AGR-1 Experiment in ATR B-10 Position,” ECAR-958, Rev. 2, September 2013, Idaho National Laboratory.

Sterbentz, J.W., 2014, "JMOCUP As-Run Daily Depletion Calculation for the AGR-2 Experiment in ATR B-12 Position,” ECAR-2066, Rev. 2, April 2014, Idaho National Laboratory.

Sterbentz, J.W., 2015, "JMOCUP As-Run Daily Physics Depletion Calculation for the AGR-3/4 TRISO Particle Experiment in ATR Northeast Flux Trap,” ECAR-2753, Rev. 1, July 2015, Idaho National Laboratory.

Trang-le, T., 2018, “Gamma Energy Analysis (GEA)”, ASR 475.01, Batch 6, June 2018, Pacific Northwest National Laboratory. 


\section{Appendix A}

\section{Analytical Laboratory Report Numbers}




\section{Appendix A}

\section{Analytical Laboratory Report Numbers}

\begin{tabular}{|c|c|c|}
\hline \multicolumn{3}{|c|}{ Through Tubes } \\
\hline Capsule & Leach Gamma and Sr-90 & ICP-MS \\
\hline 1 & 99181 & 100824 \\
\hline 2 & 99182 & 100825 \\
\hline 3 & 99209 & 100830 \\
\hline 4 & 99183 & 100826 \\
\hline 5 & 99184 & 100827 \\
\hline 6 & 99185 & 100828 \\
\hline 7 & 99186 & 100829 \\
\hline 8 & 99210 & 100831 \\
\hline 9 & 99211 & 100832 \\
\hline 10 & 99212 & 100833 \\
\hline 11 & 99213 & 100834 \\
\hline 12 & 99214 & 100835 \\
\hline
\end{tabular}

\begin{tabular}{|c|c|c|}
\hline \multicolumn{3}{|c|}{ Sink rings } \\
\hline Capsule & Solid gamma & Leach Gamma, Sr-90, ICP-MS \\
\hline 1 & 99442 and 99443 & 99443 \\
\hline 2 & 100360 & 100360 \\
\hline 3 & 99444 & 99444 \\
\hline 4 & 100932 & 100932 \\
\hline 5 & 100255 & 100255 \\
\hline 6 & 100361 & 100361 \\
\hline 7 & 99445 & 99445 \\
\hline 8 & 100256 & 100256 \\
\hline 9 & 100362 & 100362 \\
\hline 10 & 100257 & 100257 \\
\hline 11 & 100933 & 100933 \\
\hline 12 & 100363 & 100363 \\
\hline
\end{tabular}




\begin{tabular}{|c|c|}
\hline \multicolumn{2}{|c|}{ Foils } \\
\hline Capsule & Solid gamma, Leach gamma, Sr-90 and ICP-MS \\
\hline 1 & 101082 \\
\hline 2 & 101083 \\
\hline 3 & 101084 \\
\hline 4 & Capsule 4 foils not recovered \\
\hline 5 & 101085 \\
\hline 6 & 101086 \\
\hline 7 & 101087 \\
\hline 8 & 101088 \\
\hline 9 & 101089 \\
\hline 10 & 101090 \\
\hline 11 & 101091 \\
\hline 12 & 101092 \\
\hline
\end{tabular}

\begin{tabular}{|c|c|}
\hline \multicolumn{2}{|c|}{ Spacers } \\
\hline Capsule & Solid gamma, Leach gamma, Sr-90 and ICP-MS \\
\hline 1 & 101007 \\
\hline 2 & 101008 \\
\hline 3 & 100998 \\
\hline 4 & 101009 \\
\hline 5 & Capsule 5 spacers not recovered \\
\hline 6 & 101010 \\
\hline 7 & 101011 \\
\hline 8 & 101012 \\
\hline 9 & 101018 \\
\hline 10 & 101013 \\
\hline 11 & 101014 \\
\hline 12 & 101015 \\
\hline
\end{tabular}




\begin{tabular}{|c|c|}
\hline \multicolumn{2}{|c|}{ Felts, Screws, Misc Graphite } \\
\hline Capsule & Solid gamma \\
\hline 1 & Counted on HOGS \\
\hline 2 & Counted on HOGS \\
\hline 3 & Counted on HOGS \\
\hline 4 & Not recovered \\
\hline 5 & Counted on HOGS \\
\hline 6 & Counted on HOGS \\
\hline 7 & Felts counted under AL\#102210, Screws and Misc Graphite counted on HOGS \\
\hline 8 & Counted on HOGS \\
\hline 9 & Counted on HOGS \\
\hline 10 & Felts counted under AL\#102210, Screws counted on HOGS \\
\hline 11 & Counted on HOGS \\
\hline 12 & \\
\hline
\end{tabular}

